$\mathrm{DOE} / \mathrm{ET} / 28392-43$

78-28392.a.1.6

TOPICAL REPORT

\title{
GEOCHEMISTRY OF SERICITE AND CHLORITE IN WELL 14-2 ROOSEVELT HOT SPRINGS GEOTHERMAL SYSTEM AND IN MINERALIZED HYDROTHERMAL SYSTEMS
}

\author{
by \\ Judith M. Ballantyne
}

Department of Geology and Geophysics

University of Utah

June 1980 


\section{DISCLAIMER}

This report was prepared as an account of work sponsored by an agency of the United States Government. Neither the United States Government nor any agency Thereof, nor any of their employees, makes any warranty, express or implied, or assumes any legal liability or responsibility for the accuracy, completeness, or usefulness of any information, apparatus, product, or process disclosed, or represents that its use would not infringe privately owned rights. Reference herein to any specific commercial product, process, or service by trade name, trademark, manufacturer, or otherwise does not necessarily constitute or imply its endorsement, recommendation, or favoring by the United States Government or any agency thereof. The views and opinions of authors expressed herein do not necessarily state or reflect those of the United States Government or any agency thereof. 


\section{DISCLAIMER}

Portions of this document may be illegible in electronic image products. Images are produced from the best available original document. 


\section{NOTICE}

This report was prepared to document work sponsored by the United

States Government. Neither the United States nor its agent, the United States Department of Energy, nor any Federal employees, nor any of their contractors, subcontractors or their employees, makes any warranty, express or implied, or assumes any legal liability or responsibility for the accuracy, completeness, or usefulness of any information, apparatus, product or process disclosed, or represents that its use would not infringe privately owned rights.

\section{NOTICE}

Reference to a company or product name does not imply approval or recommendation of the product by the University of Utah or the U.S. Department of Energy to the exclusion of others that may be suitable.

\begin{tabular}{|c|}
\hline 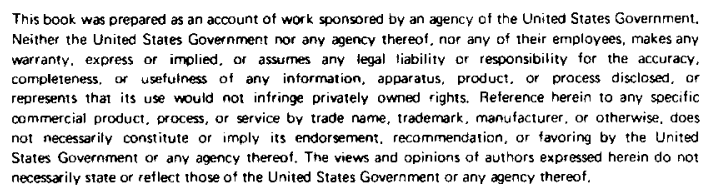 \\
\hline
\end{tabular}




\section{TABLE OF CONTENTS}

Page

LIST OF.FIGURES . . . . • . . • . . . . . . . . . . v

$\because \quad$ LIST OF TABLES. . . . . . . . . . . . . . . . . vi

LIST OF APPENDICES. . . . . . . . . . . . . . . . . vi

ABSTRACT. . . . . . . . . . . . . . . . . . . 1

INTRODUCTION. . . . .................... 4

PREVIOUS WORK . . . . . . . . . . . . . . . . . . . 11

HYDROTHERMAL ALTERATION ................... 14

Roosevelt Well14-2................. 14

Porphyry Copper Systems. . . . . . . . . . . 15

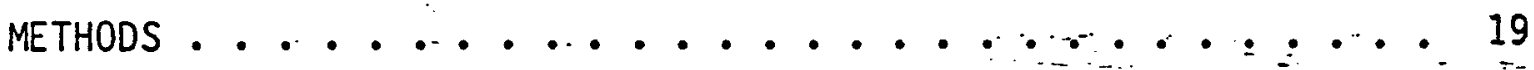

Analytical Techniques. . . . . . . . . . . . .

Choice of Samples. . . . . . . . . . . . . . 20

Sericite and Chlorite Nomenclature ............. 21

Structural Formula Calculations. . . . . . . . . 22

Analys is of Variance .................. 22

ANALYTICAL RESULTS. . . . . . . . . . . . . . . 25

Sample Variability ................ 25

Sericite Chemistry................... 26

Chlorite Chemistry.................. 43

Host Mineral Effect.................. 50

Whole Rock Chemistry Effect. . . . . . . . . . . . . 50

Coexisting Sericite and Chlorite ............. 52

THERMODYNAMIC INTERPRETATION..................... 56

Attainment of Equilibrium. . . - . . . . . . . . 56

Host Mineral Control on Alteration Mineral Chemistry . . . 57

Sensitivity of Mineral. Chemistry to Fluid Composition

and Temperature. .................... 59

Fluid Compositions ................... 61

Mineral-Fluid Energy Relationships............ 63

SUMMARY AND CONCLUSIONS . . . . . . . . . . . . . . 76 


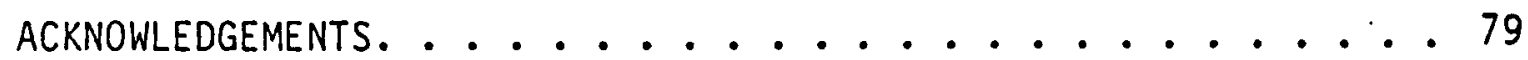

REFERENCES. .................... 80 


\section{LIST OF FIGURES}

Page

1. Locations of hydrothermal systems . . . . . . . . . 5

2. Alteration in Well 14-2, Roosevelt Hot Springs. . . . . . 7

3. Compositional heterogeneity in sericites: an example. . . . 27

4. Element distribution in sericite, Southwest Tintic, Utah. . . 28

5. Element distribution in sericite, Santa Rita, New Mexico. . . 29

6. Element distribution in sericite, Well 14-2, Roosevelt Hot Springs, Utah ........................ 31

7. Interlayer vs tetrahedral site occupancy in sericite, Well 14-2, Roosevelt Hot Springs ................ 33.

8. Octahedral cation distribution in sericite from Well 14-2, Roosevelt Hot Springs ............. 35

9. $\mathrm{Mg} 2+$ vs $\mathrm{F}^{-}$relationship in sericite from three hydrothermal systems . . . . . . . . . . . . . . . . . . . 36

10. Effect of alteration assemblage on sericite in Well 14-2, Roosevelt Hot Springs ...................

11. Interlayer vs tetrahedral site occupancy in sericite, Southwest Tintic............................

12. Octahedral cation distribution in sericite from Southwest

$\because$ Tintic.............................

13. Interlayer vs tetrahedral site occupancy in sericite, Santa

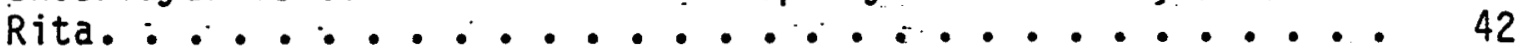

14: Octatiedral cation distribution in sericite from Santa Rita. . . 44

15. Octahedral cation distribution in sericite from five areas. $\quad \therefore 45$

16. Chiorite composition and nomenclature . . . . . . . . 48

17. Octahedral cation distribution in chlorite from four hydrothermal systems: Southwest Tintic, Silver Bell, Salton Sea and 
Roosevelt Hot Springs...............

18. Effect of host mineral replaced on chlorite composition, Well

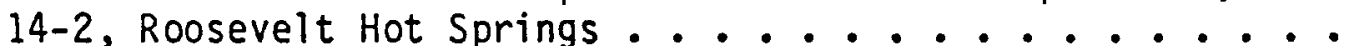

19. Octahedral cation distribution in coexisting sericite and

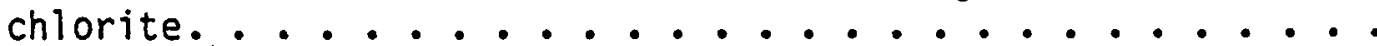

20. Element partitioning in coexisting sericite and chlorite. . . 54

21. Fluid-mineral energy relationship: departure from equilibrium - 70 


\section{LIST OF TABLES}

Page

1. Alteration assemblages, Southwest Tintic. . . . . . . . 17

2. Alteration assemblages; Santa Rita... . . . . . 18

3. Water analysis: Thermal Power Company Well 14-2, Roosevelt Hot Springs ...................... 62

4. Calculated activities of aqueous species in Well 14-2 fluid assuming $10 \%$ and $20 \%$ steam loss ..................... 65

5. Hydrolysis reaction equilibrium constants $(K)$ and Ion Activity Products (IAP) for Well 14-2 . . . . . . . . - 69

\section{LIST OF APPENDICES}

I. Sericite analyses: Southwest Tintic............ $\overline{86}$

II. Sericite analyses:- Santa Rita. . . . . . . . . . 89

III. Sericite analyses: Roosevelt Well 14-2 . . . . . . . . 90

IV. Chlorite analyses: Southwest Tintic........... 91

V. Thermodynamic properties of minerals. . . . . . . . . 92 


\section{ABSTRACT}

Chemical compositions of chlorite and sericite from one production well in the Roosevelt geothermal system have been determined by electron probe methods and compared with compositions of chlorite and sericite from porphyry copper deposits. Modern system sericite and chlorite occur over a depth interval of $2 \mathrm{~km}$ and a temperature interval of $250^{\circ} \mathrm{C}$.

Mineral compositional variation within samples of cuttings from individual depth intervals from the geothermal well is as large as that between samples, and is sufficiently large to obscure any effects related to present day hot water entry zones, at least on the scale. sampled. Recent suggestions are that the well may have been drilled parallel and close to a major fluid bearing fracture, and if so would not provide a good test situation. Sericites range between illites and muscovites on the basis of $K$ and Si content. Chlorites are ripidolites, brunsvigites and pycnochlorites. Sericite compositional ranges are 0.6 to $1.0 \mathrm{~K}, 3.1$ to $3.5 \mathrm{Si} ; 0.0$ to $0.3 \mathrm{Fe}, 0.0$ to $0.3 \mathrm{Mg}$ and 1.7 to 2.8. Al per formula unit. $\mathrm{Fe} / \mathrm{Mg}$ is usually near 1. Chlorites contain-2.8 to $3.2 \mathrm{si}, 1.9$ to $2.5 \mathrm{Al}, 1.7$ to $2.6 \mathrm{Fe}$ and 1.3 to $2.4 \mathrm{Mg}$.

Comparison with porphyry copper systems shows that interlayer chemistry in hydrothermal sericites is related to the alteration assemblage, and chemical heterogeneity is related to alteration 
intensity or extent of recrystallization of the rock. Analyzed chlorite compositions in porphyry systems are similar to or more magnesian than those at Roosevelt. Sericites from porphyry systems tend to have higher interlayer $(\mathrm{K}+\mathrm{Na})$ site occupancies and less $\mathrm{Si}$ in tetrahedral sites than those from Roosevelt. Southwest Tintic sericites have nearly constant $\mathrm{Fe}$ but variable $\mathrm{Al}$ and $\mathrm{Mg}$ in octahedral sites, Santa Rita sericites have nearly constant Mg, and Roosevelt sericites nearly constant $\mathrm{Fe} / \mathrm{Mg}$. The differences between systems may be at least partiy due to differences in alteration assemblages analyzed. F correlates with $\mathrm{Mg}$ content in sericites from all systems. Sericite and chlorite chemistry is a function, not merely of bulk fluid chemistry and temperature, but also of the _local chemical . environment, distance from fluid-bearing veins, and the type of mineral being replaced. Thermodynamic modeling shows that the sensitivity of sericite and chlorite chemistry to fluid composition is such that changes in aqueous species activities can cause changes of similar magnitude in the activities of solid solution end members. Temperature changes of a few tens of degrees can cause order of magnitude changes in solid phase activities.

Chemical inhomogeneity of alteration minerals, isotopic evidence and thermodynamic modeling indicate a state of disequilibrium between the Roosevelt buik geothermal fluid and hydrothermal sericite and chlorite. The amount of disequilibrium calculated depends upon the thermodynamic data base used. Alteration minerals may well be in equilibrium with local portions of the present day fluid which have changed composition by reacting with the rock. Sericite solid 
solution end members and calcite appear to be close to equilibrium with the bulk fluid, feldspars are slightly undersaturated, and chlorite is strongly undersaturated. These data suggest, unless the chlorite thermodynamic data is highly inaccurate, that chlorite may have formed earlier, perhaps during a previous hydrothermal event. 


\section{INTRODUCTION}

In a hydrothermal system the chemistry of alteration minerals is a function of the temperature, pressure and solution composition. .. Theoretically, alteration minerals may be regarded as retaining an imprint of the characteristics of that fluid, providing no subsequent changes take place. If the alteration minerals were in equilibrium with the hydrothermal fluid, information about the composition of that fluid may be extracted by means of thermodynamics. Hence the potential exists for using hydrothermal mineral chemistry to locate or correlate hot water conduits in geothermal systems, to distinguish alteration due to different hydrothermal events, and even to trace fluid evolution within a geothermal field.

A practical evaluation of the feasibility of using alteration. mineral chemistry in geothermal exploration häs been the subject of this study. The evaluation has had two focuses: 1) on characterizing sericite and chlorite chemistry from both present day and fossil hydrothermal systems, and 2) on constructing a thermodynamic model to relate mineral chemistry to associated fluid chemistry: Microprobe

$\therefore \quad$ analyzes of hydrothermal sericite and chlorite have been obtained for samples from Well 14-2 (Thermal Power Company) at the Roosevelt Hot Springs geothermal system and for samples from the Southwest Tintic porphyry copper system, both in Utah. Sericites from the Santa Rita porphyry copper deposit in Arizona and chlorites from the Silver Bell deposit in New Mexico are included for comparison (locations in Figure 1). Equilibrium between rock and fluid has probably been attained in 


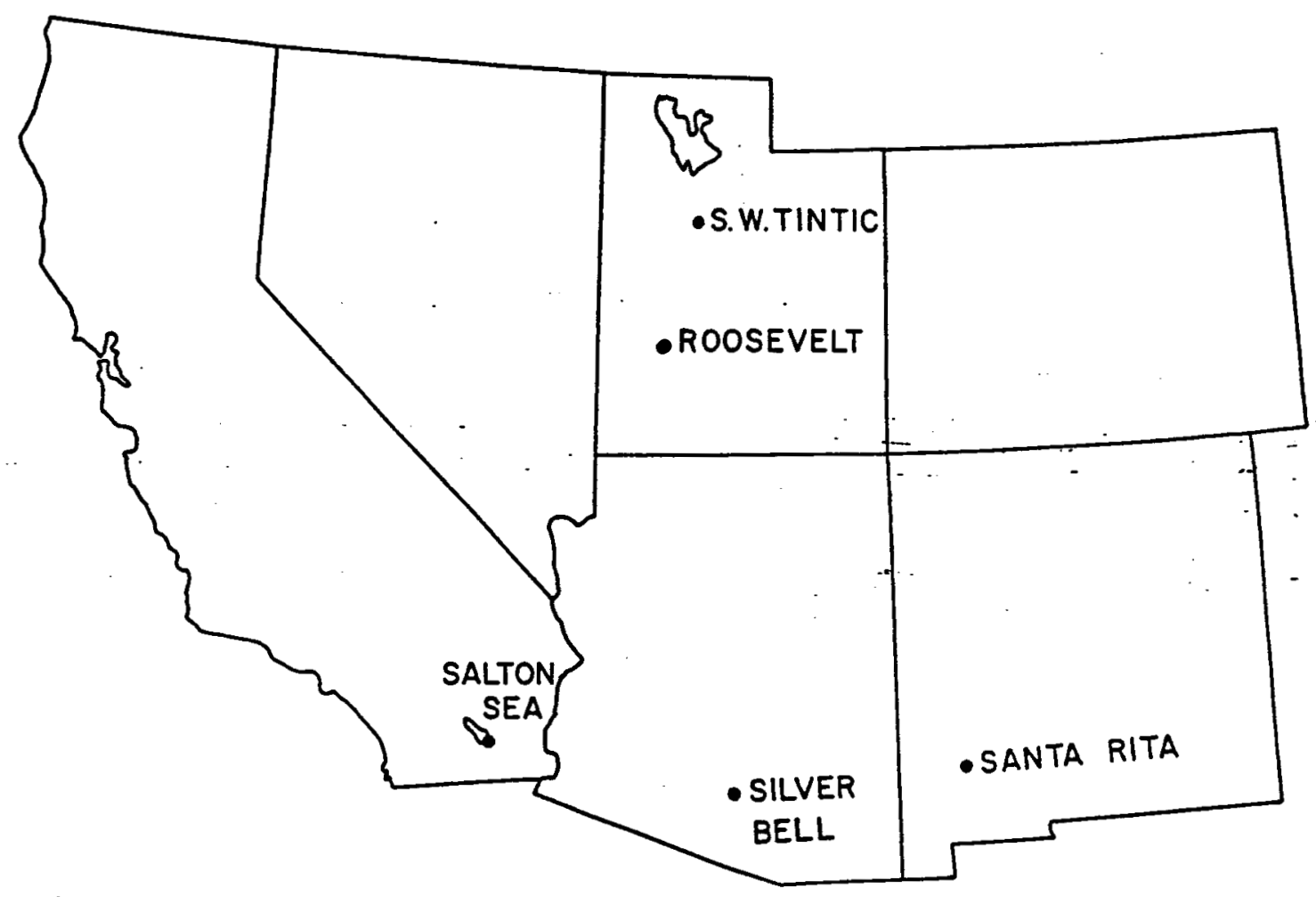

Figure 1. Locations of hydrothermal systems. 
the pervasively aitered and recrystallized porphyry systems, but several lines of evidence indicate that overall equilibrium between alteration minerals and the bulk geothermal fluid at Roosevelt has not been àttained.

- Hydrothermal alteration at shallow depths (above $70 \mathrm{~m}$ ) in the Roosevelt Hot Springs geothermal system has been described by Parry et al. (1980). A detailed petrographic study of the lithologies and alteration in well 14-2 has been reported by Ballantyne and Parry (1978) and is sumarized in Figure 2 reproduced from that report. The alteration occurs in Tertiary monzonite and associated dikes, and probable xenoliths of Precambrian gneiss. Alteration assemblages are weak to moderate phyllic in the upper portions of the well, and weak propylitic in the lower portions. Alteration intensity-is strongernear fluid-bearing fractures. Mineral assemblages for the individual samples are discussed later. Alteration zone terminology is after Lowell and Guilbert (1970).

At Southwest Tintic the host rocks for alteration are andesite and latite volcanics, mainly tuffs with local flows and intrusive rocks. The alteration assemblages vary from a central potassic zone through a phyllic zone to propylitic. "The phyllic zone at Tintic is extensive, and is usually, but not ubiquitously, present between the potassic and propylitic zones.

At Santa Rita the host for alteration is the granodiorite of the Santa Rita stock. Potassic zone sericites have been analyzed. All Santa Rita sericite samples included here were analyzed by David $C$. Jacobs. All but two contain hydrothermal biotite in addition to 
Figure 2. Hydrothermal Alteration in Wel7-14-2: Products and extent... of alteration. Horizontal bars on plagioclase destruction graph = indicate range of plagioclase destruction observed in a thin section. Abbreviations: B, barite; C, chalcopyrite; Ca, calcite; $\mathrm{Ch}$, chlorite; $\mathrm{Cl}, \mathrm{Cl}$ ay; Gy, gypsum; $\mathrm{H}$, hematite; $\mathrm{K}, \mathrm{K}$-feldspar; Mo, Montmorillonite; Mt, magnetite; Py, pyrite; $Q$, quartz; S, sericite; Ti, leuxocene. (Modified from Baliantyne and Parry, 1978.) 

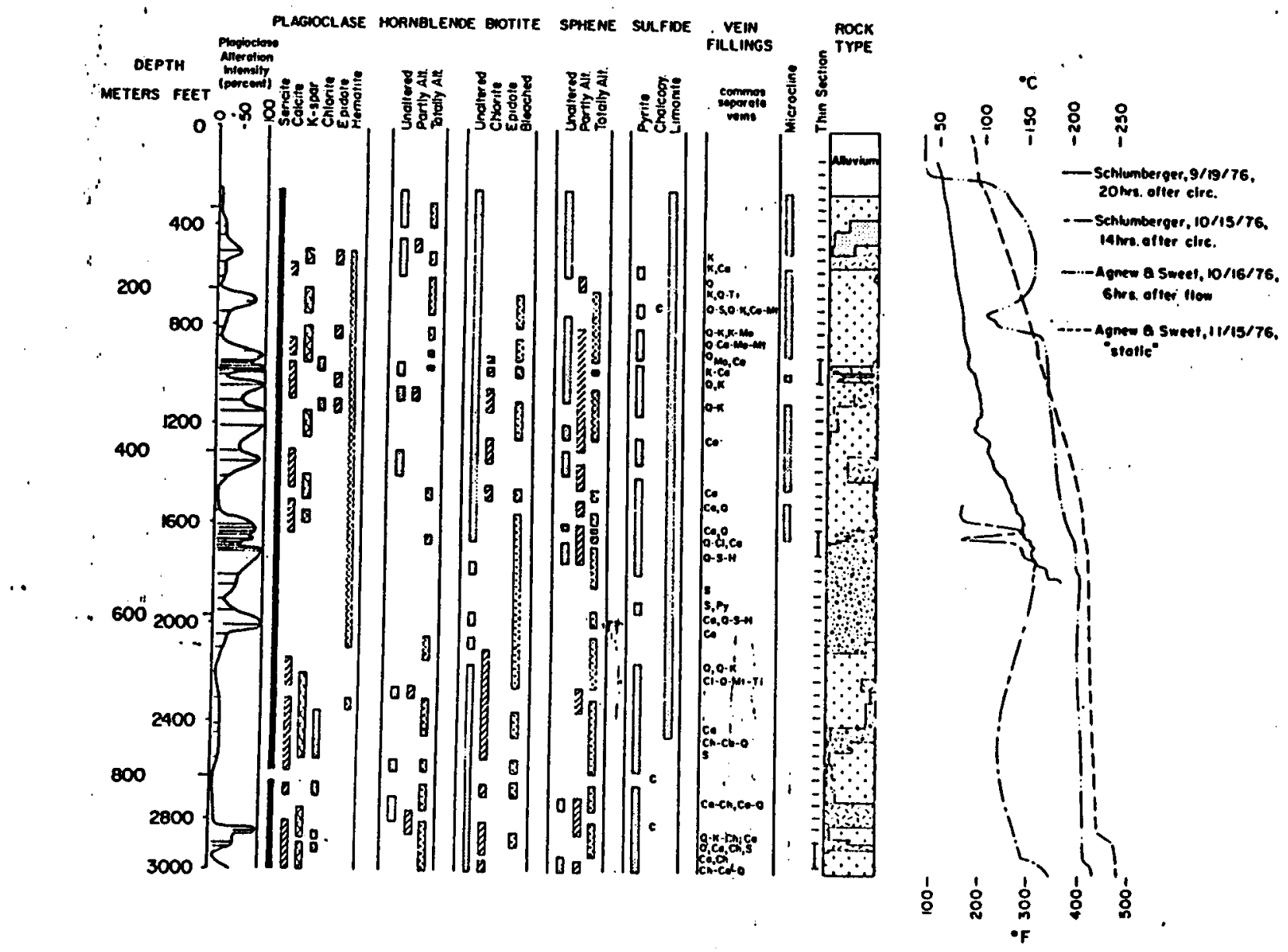


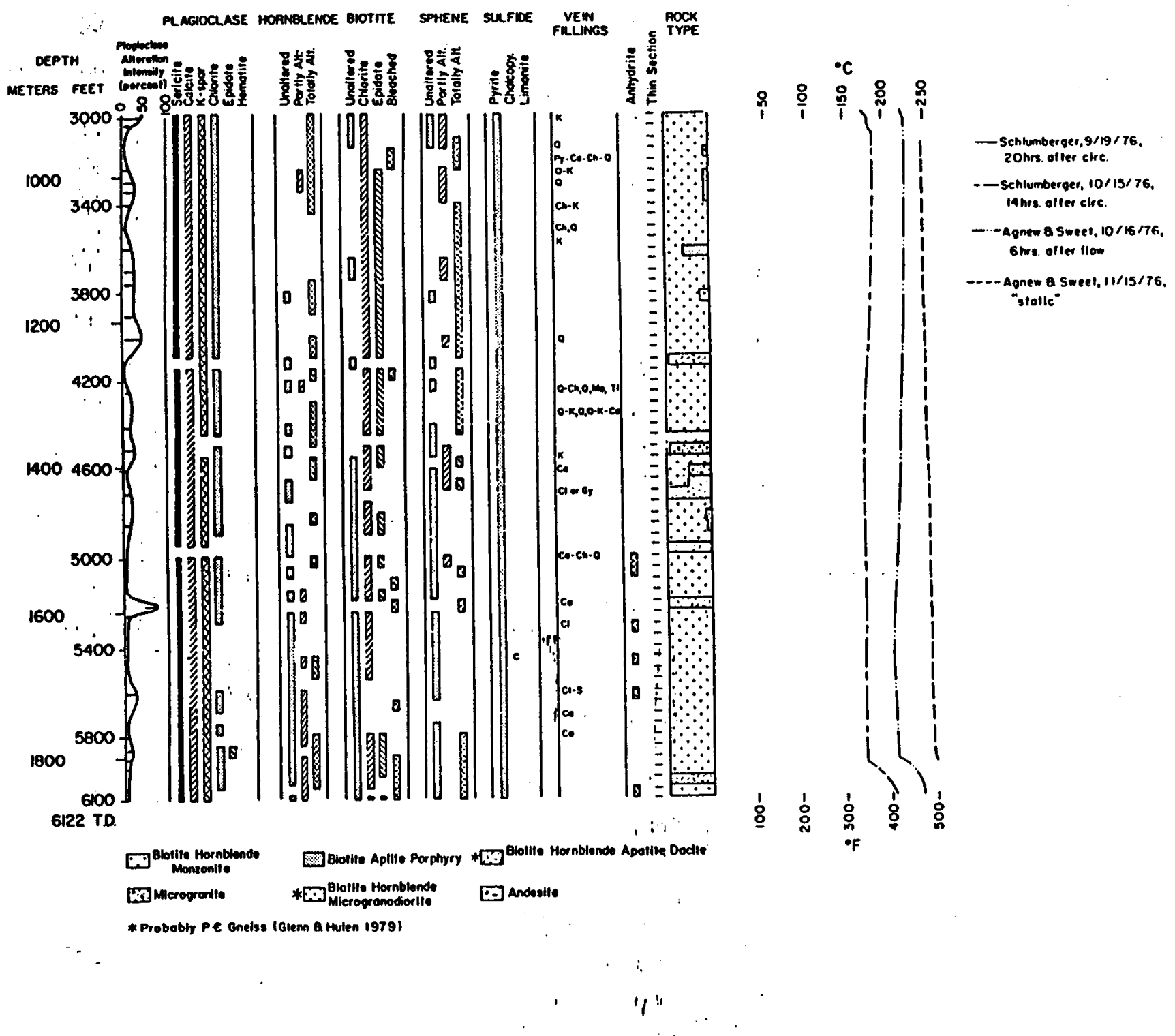


sericite, and several also contain chlorite.

Silver Bell chlorites from propylitized rhyodacite porphyry were analyzed by Geoffrey H. Ballantyne. 
PREVIOUS WORK

Electron microprobe analyzes of sericite and chlorite, appearing in the literature of the past decade include reports of individual analyses and studies of systematic compositional variations. Prior to and contemporaneous with microprobe investigations, $X$-ray diffraction studies have provided information on the nature and distribution of phyllosilicates in hydrothermal and sedimentary diagenetic environments.

$x$-ray diffraction studies of clay and mixed-layer minerals in $=$ geothermal systems indicate a transition from smectite through increasingly illitic mixed layer illite/smectite to illite and finally phengitic mica as depth and temperature increase. These modifications are observed in the Salton Sea by Muffler and White (1969) and McDowell (1978), at Wairakei by Steiner (1968) and at the Broadlands and Ohaki-Broadlands fields by Brown and Ellis (1970) and Eslinger and Savin (1973). Although the role of fluid chemistry is important the conversion to illite appears to be complete: in all cases by $230^{\circ} \mathrm{C}$ (Eslinger and Savin, .-1973) and in the Saiton Sea by $210^{\circ} \mathrm{C}$ (Muffler and White, 1969). Discrete montmorillonite converts to mixed layer illite/smectite below $100^{\circ} \mathrm{C}$ (Muffler and White, 1969).

A swelling, mixed layer chlorite/smectite has been noted at Wairakei in one well sample from a sheared zone at approximately $207^{\circ} \mathrm{C}$ 
by Steiner (1968), and at the Ohaki-Broadlands field in several low temperature (between 100 and $150^{\circ} \mathrm{C}$ ) shallow depth locations by Eslinger and Savin (1973).

Similar changes in interlayered $i l l i t e /$ smectites have been observed in sedimentary rocks as the degree of diagenesis and depth of burial increases. Chlorite also occurs as a mixed layer chlorite-smectite of the corrensite type in certain situations. Dunoyer de Segonzac (1970) reviewed the transformation of clay minerals during diagenesis and low grade metamorphism. More recent studies of illite and mixed layer illite/smectite include those by Eslinger et al. (1979) and Eberl and Hower (1977). Weaver (1979) discussed diagenetic and geothermal alteration of clay minerals. Blatter et al. (1972) report interstratified chlorite-dioctahedralsmectite in dike-intruded shales and report other such occurrences. from the literature.

McDowell (1978) showed regular changes in sericite and chlorite chemistry with increasing depth and temperature in Well Elmore \#I in the Salton Sea geothermal field, in the range 190 to $322^{\circ} \mathrm{C}$. Guilbert and Schafer (1978) found apparently systematic variations in both major and trace elements in sericites from porphyry base metal deposits. Downey (1976) analyzed chlorites from the propylitically altered pluton at Gold Hill, Utah, without finding systematic geographic variation. Systematic changes in muscovite composition with increasing metamorphic grade in pelitic schists have been noted by Guidotti (1973 and 1978) and Cheney and Guidotti (1973). Page and Wenk (1979) report regular variations in sericite chemistry and 
alteration assemblage in the selvedge of a vein at Butte, Montana. Individual analyses of sericite and chlorite from mineralized hydrothermal systems have been reported by Ashley (1980), Kulvanich (1975) reported in Kelley and Rye (1980), Nash (1973), Chivas (1978), Ford (1978), and Ashley et al. (1978). 
HYDROTHERMAL ALTERATION

Roosevelt Well 14-2

Fluid flow in the Roosevelt geothermal system is fracture controlled, and hydrothermal alteration is thus also closely related to faults and fractures. Alteration assemblages in well 14-2 are

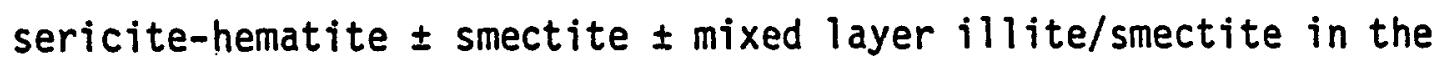
upper 790 meters, and chlorite-sericite-calcite-pyrite at depth, with traces of anhydrite below $1525 \mathrm{~m}$. Total well depth is $1866 \mathrm{~m}$. A transition zone occurs between the upper and lower assemblages. Epidote is present in trace amounts replacing plagioclase between 150 and $350 \mathrm{~m}$ and at $1784 \mathrm{~m}$ (Figure 2).

Sericite is abundant above $650 \mathrm{~m}$, occurring mainiy as plagiociase replacements and in veinlets and fracture fillings. The degree of plagioclase destruction in any one thin section of cuttings usually varies, some grains being almost unaltered, others partiy or totally replaced by sericite. The range of plagioclase destruction is shown in Figure 2, the curve linking maximum destruction in each sample. Below $650 \mathrm{~m}$ sericite is less common, and alteration intensity in general is diminished. The degree of alteration is probably related to distance from fluid-bearing veins and to fracture intensity. X-ray diffractograms of clay minerals from well 14-2 reported by Parry (1978) indicate the presence of montmorillonite somewhat sporadically between 275 and $455 \mathrm{~m}$, and mixed layer illite-smectite between 30 and $60 \mathrm{~m}$, near $150: \mathrm{m}$ and between 240 and $305 \mathrm{~m}$ (all below 
$150^{\circ} \mathrm{C}$ ). Three other occurrences of $1111 \mathrm{ite} /$ smectite occur at 565,655 , and $878 \mathrm{~m}$. K-mica is present in all diffractograms, and chlorite appears below $716 \mathrm{~m}$.

A brief review of the diffraction data during the present study for mixed layer chlorite-smectite found one probably spurious peak. Corrensite may exist elsewhere in the well in amounts too small (less than $5 \%$ of the clay concentrate) to be detected by the XRD equipment. Microprobe analyses of an expanded mica in a monomineralic chip from $869 \mathrm{~m}$ indicate a mixed-layer chlorite-illite, having calculated cation contents of $2.14 \mathrm{Fe}^{2+} t, 1.34 \mathrm{Mg}^{2+}$ and $0.41 \mathrm{~K}^{+}$. Analytical data do not fit a vermiculite structure. The appearance of this mineral suggests it is a discrete phase.

\section{Porphyry Copper Systems}

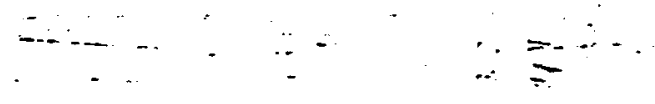

Southwest Tintic alteration assemblages äre typical for porphyry copper systems (Lowell and Guilbert, 1970; Rose and Burt, 1979). An inner potassic zone of secondary biotite \pm pyrite \pm orthoclase \pm quartz \pm anhydrite \pm amphibole \pm magnetite \pm chalcopyrite is overlain and in part surrounded by a phyllic zone of quartz-sericite-pyriterutile (or anatase) \pm colorless chlorite \pm apatite \pm tourmaline. A wide zone of propylitic alteration surrounds the phyllic zone and locally abuts potassic alteration without an intervening phyllic zone. Propylitic zone mineralogy includes epidote, chlorite, calcite, pyrite, sericite, albite, and actinolite. X-ray diffraction patterns also show the presence of kaolinite, montmorillonite, and mixed layer illite/smectite in many samples. The mineralogy of individual 
microprobe samples is presented in Table 1.

Jacobs (1976) presents detailed descriptions of alteration

mineralogy in the Santa Rita samples discussed in this report. All

are from the potassic zone, and all but two contain secondary biotite.

Mineralogy of individual samples is summarized in Table 2.

Silver Bell samples are from propylitically altered rocks.

Minerals associated with chlorite include calcite, epidote, pyrite,

and actinolite (G. H. Ballantyne, personal communication). 
Table 1. Alteration Assemblages, Southwest Tintic

\section{Sample \#}

1

3 .

4

5

6

7
Assemblage

Potassic

Phyllic

Phyllic

Phyllic-Propylitic

Phyllic-Propylitic

Propylitic
Secondary Minerals

Biotite, sericite, chlorite, pyrite, $\mathrm{TiO}_{2}$ in rock matrix.

Veins: quartz-biotite-chloritesericite-apatite-pyrite

Quartz-sericite-chlorite- $\mathrm{TiO}_{2}-$ pyrite superimposed on secondary biotite

Quartz-sericite-pyrite-kaoliniteillite/smectite- $\mathrm{TiO}_{2}$

Quart-sericite-tourmal ine-kaol inite-illite/smectite-trace remnant epidote- $\mathrm{TiO}_{2}$, no pyrite

Quartz-sericite-pyrite-chlorite, $\mathrm{TiO}_{2}$. $\mathrm{Tr}$ chlorite as radiating clusters

Sericite-chlorite-pyrite-kaoliniteillite/smectite- $\mathrm{TiO}_{2}$. Quartzsericite veins

Chlorite-epidote-sericite-albitepyrite-calcite- $\mathrm{TiO}_{2}$ 
Table 2. Alteration Assemblages, Santa Rita*

\begin{tabular}{|c|c|c|}
\hline Sample \# & Assemblage & Secondary Minerals \\
\hline $72-9-11$ & Potassic-Argillic & $\begin{array}{l}\text { biot, ksp, qtz, mt, py, cpy, mont, } \\
\text { kaol, ser, chl repi biot. musc } \\
\text { in qtz-musc-mt-ksp vnits }\end{array}$ \\
\hline $72-9-17$ & $\begin{array}{l}\text { Potassic-Phyllic- } \\
\text { Argillic }\end{array}$ & $\begin{array}{l}\text { biot, ksp, qtz, py, cpy, mont, } \\
\text { kaol, ser, musc, ant }\end{array}$ \\
\hline $72-9-18$ & Potassic-Phyllic & $\begin{array}{l}\text { biot, Ksp, qtz, ap, py, cpy, musc, } \\
\text { ant }\end{array}$ \\
\hline $72-9-20$ & $\begin{array}{l}\text { Potassic-Argillic- } \\
\text { Phyllic }\end{array}$ & $\begin{array}{l}\text { biot, Ksp, qtz, kaol, mont, ser, } \\
\text { py, cpy chl repl biot }\end{array}$ \\
\hline $72-9-21$ & $\begin{array}{l}\text { Potassic-Argillic- } \\
\text { Phyllic }\end{array}$ & $\begin{array}{l}\text { biot, Ksp, gtz, mont, kaol, ser, } \\
\text { py, ant,-wk chl repl biot }\end{array}$ \\
\hline $72-9-28$ & Propylitic-potassic & $\begin{array}{l}\text { chl, epid, mt, sph, musc, mont; } \\
\text { kaol, all biot alt to chi }\end{array}$ \\
\hline $72-9-30$ & Propylitic-Potassic & $\begin{array}{l}\text { Ksp, qtz, chl, epid, mt, sid, sph, } \\
\text { ap, py, ser, kaol, mont. all biot } \\
\text { alt to chl and epid }\end{array}$ \\
\hline \multirow[t]{2}{*}{$72-9-50$} & $\begin{array}{l}\text { Potassic-Argillic- } \\
\text { Phyllic }\end{array}$ & $\begin{array}{l}\text { biot, Ksp, qtz, cpy, mont, kaol, } \\
\text { musc, py, ser }\end{array}$ \\
\hline & & $\therefore$ \\
\hline \multicolumn{3}{|c|}{$\begin{array}{l}\text { ** Abbreviations: alt (altered), ant (anatase), ap (apatite), biot } \\
\therefore \text { (biotite), chi (chlorite), cpy (chalcopyrite), epid (epidote), } \\
\text { kaol (kaolinite), Ksp (K-feldspar), mont (montmorillonite), mt } \\
\text { (magnetite), musc (muscovite), py (pyrite), qtz (quartz), repl } \\
\text { (replaces), ser (sericite), sid (siderite), sph (sphene), vnlets } \\
\text { (veinlets), wk (weak) }\end{array}$} \\
\hline
\end{tabular}




\section{METHODS}

\section{Choice of Samples}

Samples from Well 14-2 for microprobe analysis were chosen to include strongly altered rocks near two recognized hot water entry zones (major fracture zones corresponding to temperature increases), and also to include rocks between and beneath these zones. The upper "hot water entry" near $500 \mathrm{~m}$ (the well is presently cased to $551 \mathrm{~m}$ ) is tested by samples at 503 and $518 \mathrm{~m}$, and the second between 850 and 900 $\mathrm{m}$ is tested by samples at 854,869 and $896 \mathrm{~m}$. A sample at $610 \mathrm{~m}$ lies between the two entry zones, and two at 1341 and 1524 test relatively: weakly altered deep levels. The alteration assemblage in the upper three samples $(503,518$ and $610 \mathrm{~m}$ ) is seritite-hematite (no mixed layer clay or smectite is present in X-ray diffractograms) and in the remaining samples is chlorite-sericite-calcite-pyrite.

The Southwest Tintic samples were chosen to represent different alteration assemblages from a relatively small geographic area and include samples from the potassic zone, potassic-phyllic boundary, the phyllic zone and the propylitic zone. As previously discussed, Santa Rita sericite samples are from the potassic'zone. No chlorite analyses from Santa Rita are presented. Silver Bell samples are chlorites from the propylitic zone. 


\section{Analytical Techniques}

Minerals were analyzed using a 3-channel ARL electron microprobe at an acceleration voltage of $15 \mathrm{kv}$ for a fixed total integrated beam current achieved in approximately 13 seconds and with a sample current of .03 microamps. An attached Tracor Northern energy dispersive unit provides an energy spectrum on a visual display unit which, while not quantitative, can be used to identify mineral phases by the relative concentrations of the elements present. A beam approximately 1 micron in diameter was used because of the fine-grained nature of many of the hydrothermal minerals. Typically ten spots were analyzed for each mineral grain or, in the case of fine grained minerals, for each aggregate in a particular environment in any one chip. For each spot the energy spectrum from 0 to $10 \mathrm{kev}$ was checked to ensure correct identification of the mineral phase concerned. This is particulariy important with fine grained hydrothermal minerals where, for example, .. chlorite and sericite or albite are intermixed on a fine scale and are not distinguishable with the microprobe optics. Analytical accuracy was checked using a sample of Methuen Muscovite analyzed by the U.S. Geological Survey (G. K. Czamanske, personal communication).

For sericite, chlorite, hornblende and biotite analyses, the standards used were amphibole, pyroxene, biotite, and scapolite. Standards for Santa Rita samples, analyzed by D. C. Jacobs, were biotites, muscovite and scapolite. Bence-Albee matrix corrections (Bence and Albee, 1968; Albee and Ray, 1970) were performed and a structural formula calculated. Input data to the Bence-Albee routine includes an ideal water content and a typical ferric to ferrous iron 
ratio for the mineral concerned. The data are corrected by an iterative routine which corrects the original oxide data each time with successively more accurate approximations of water content, computed from the structural formula of the mineral.

Sericite and Chlorite Nomenclature

"Sericite" according to Deer, Howie and Zussman (1966) "is a term used to describe fine grained white mica (muscovite or paragonite). Such micas are not necessarily chemically different from muscovite although they often have high $\mathrm{SiO}_{2}, \mathrm{MgO}$ and $\mathrm{H}_{2} \mathrm{O}$, and low $\mathrm{K}_{2} \mathrm{O}$." Light green sericites are also observed in some hydrothermal environments. "Sericite" in this report is used to include fine grained muscovite, phengite, illite and other solid solution end members. . Phengite (high silica muscovite) is a term not used in this report. End members used in data interpretation and thermodynamic ndeling of sericite are muscovite, $\mathrm{KAl}_{2} \mathrm{Si}_{3} \mathrm{AlO}_{10} \mathrm{O}(\mathrm{OH})_{2}$, illite, K.75Mg. $25 \mathrm{Al}_{1} .75 \mathrm{Si}_{3} .5 \mathrm{Al} .5 \mathrm{O}_{10} \mathrm{O}^{-}$ $(\mathrm{OH})_{2}$, paragonite, $\mathrm{NaAl}_{2} \mathrm{Si}_{3} \mathrm{AlO}_{10}(\mathrm{OH})_{2}$, celadonite $\mathrm{KMgAlSi}{ }_{4} \mathrm{O}_{10}(\mathrm{OH})_{2}$, ferrimuscovite (a hypothetical mica) $\mathrm{KFe}_{2} \mathrm{Si}_{3} \mathrm{AlO}_{10} \mathrm{O}(\mathrm{OH})_{2}$ and pyrophyllite, $\mathrm{Al}_{2} \mathrm{Si}_{4} \mathrm{O}_{10}(\mathrm{OH})_{2}$. Note that neither a ferrous, nor a fluorine bearing end member is used. The major substituent ions in chlorite are octahedral $\mathrm{Fe}^{2+}$ and $\mathrm{Mg}^{2+}:$ The, end members used are clinochlore $\mathrm{Mg}_{5} \mathrm{AlSi}_{3} \mathrm{AlO}_{10}(\mathrm{OH})_{8}$ and daphnite $\mathrm{Fe}_{5} \mathrm{AlSi}_{3} \mathrm{Al}_{10}(\mathrm{OH})_{8} \cdot$ Variable Al3+ substitution in octahedral and tetrahedral sites is not directly treated in thermodynamic calculations. A ferric component is also not used. 
Structural Formula Calculations

Bence-Albee-corrected mineral analyses have been converted to structural formulas. Calculations are made on the basis of 22 total 0 and $(\mathrm{OH})$ charges for sericite and $280,(\mathrm{OH})$ charges for chlorite. The formulas used are $X_{a} Y_{b} Z_{4} O_{10}(O H, F, C l)_{2}$ for sericites, where a is usually between 0.7 and 1.0 , and $b$ is near 2, and for chlorite $\mathrm{Y}_{\mathrm{a}} \mathrm{Z}_{4} \mathrm{O}_{10}(\mathrm{OH}, \mathrm{F}, \mathrm{Cl})_{8}$ where $\mathrm{a}$ is near 6.0. In both minerals $\mathrm{Al}$ is partitioned according to the assumption that those of the four tetrahedral sites not filled by $S i$ are filled by $A l$. Remaining $A l$ is assigned to octahedral sites. All data plots are presented in terms of moles of ions, and employ total iron as $\mathrm{Fe}^{2+}+\mathrm{Fe}^{3+}$.

Analysis of variance

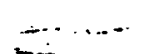

A statistical evaluation of the anaiytical results has been performed in order to compare the homogenejty-of individual crystals and aggregates with the variation that occurs between different crystals or aggregates from a sample of core or cuttings.

The chemical homogeneity of mineral grains has been estimated assuming the distribution of an element within a crystal or aggregate is normal. This assumption is probably not accurate but provides a relatively simple method for representing inhomogeneity. Most crystals are small and usually only 10 spots or fewer have been analyzed per grain. The effect of sampling bias has not been evaluated.

The standard deviation of the X-ray counts was computed using an HP25 calculator, and the square of the counting error was subtracted 
from the square of this value (the variance). The counting error is $\sqrt{N}$, where $N$ is the number of counts. The standard deviation on the counts, is the square root of

$$
\frac{\sum_{i=1}^{n}\left(x^{2}-n \bar{x}_{i}{ }^{2}\right)}{n-1}
$$

where $n$ is the number of observations, $X_{j}$ is the value of the $i$ th observation, and $X$ is the mean.

The standard deviation due to sample inhomogeneity is

$$
s=\sqrt{(S . D . \text { on counts })^{2}-\text { counts } / \text { counts }}
$$

This value was converted to weight percent (but not Bence-Albee corrected) and al so to number of ions for the structural formula

The allocation of errors to AIIV and AIVI was made using a method discussed by Holman (1978, p. 45): $\quad \leqslant \cdots-$

$$
U_{R}=\left[\sum_{i=1}^{n}\left(\frac{\partial R}{\partial x_{i}} \cdot U_{i}\right)^{2}\right]^{\frac{3}{2}}
$$

where $R$ is the parameter, $U_{R}$ is the uncertainty of the parameter, $X_{i}$ is the $i$ th component of the parameter, and $U_{i}$ is the uncertainty of the ith component.

The uncertainty of, for example, $\mathrm{Mg} / \mathrm{Fe}$, where $\mathrm{a}=\mathrm{Mg}$ and $\mathrm{b}=\mathrm{Fe}$ (where $a$ and $b$ are numbers of ions, or weight percent) is:

$$
\begin{aligned}
U_{a / b} & =\left\{\left[\frac{\partial\left(\frac{a}{b}\right)}{\partial a} b U_{a}\right]^{2}+\left[\left(\frac{\partial\left(\frac{a}{b}\right)}{\partial b}\right) \cdot U_{b}\right]^{2}\right\}^{\frac{2}{2}} \\
& =\left[\left(\frac{1}{b} \cdot U_{a}\right)^{2}+\left(\frac{a}{b^{2}} \cdot U_{b}\right)^{2}\right]^{\frac{1}{2}}
\end{aligned}
$$


The allocation of uncertainties to AIIV and AIVI rests on the assumption that $U_{a} / U_{b}=a / b$ where $A I I V=a$ and $A I V I=b$. The total uncertainty is the square root of the variances of $a$ and $b$

$$
u=\left(u_{a}^{2}+U_{b}^{2}\right)^{\frac{1}{2}}
$$

Hence

$$
\begin{aligned}
U_{a}^{2} & =\frac{U_{b}^{2} \cdot a^{2}}{b^{2}} \\
U & =\left[\left(\frac{a^{2}}{b^{2}}+1\right) U_{b}^{2}\right]^{\frac{1}{2}} \\
& =\left(\frac{a^{2}+b^{2}}{b^{2}}\right)^{\frac{2}{2}} U_{b} \\
U_{b} & =U /\left(\frac{a^{2}+b^{2}}{b^{2}}\right)^{\frac{3}{2}}
\end{aligned}
$$

Similarly

$$
u_{a}=u /\left(\frac{a^{2}+b^{2}}{a^{2}}\right)^{\frac{1}{2}}
$$
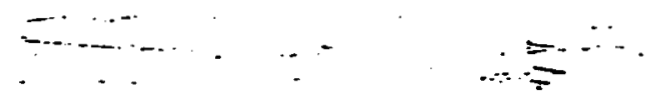

For example, if AIIV $=0.7$ and $A I V I=1.7$ and $U=0.7$, then

$$
U_{a}=0.7 /\left(\frac{(0.7)^{2}+(1.7)^{2}}{(0.7)^{2}}\right)^{\frac{3}{2}}=0.27
$$

This method is merely an approximation because uncertainties in Si and in sum of cations also have an effect, and the method assumes a normal distribution of uncertainties in both octahedral and tetrahedral sites as well as in total Aị. 


\section{ANALYTICAL RESULTS}

\section{Sample Variability}

A measure of the homogeneity of individual crystals or aggregates was obtained by analyzing approximately 10 spots per crystal or aggregate and calculating a mean and standard deviation. In most cases minerals are quite inhomogeneous. In spite of the inhomogeneity, however, mean analyses for crystals within individual samples cluster relatively closely. Some of the inhomogeneity may be due to a small amount of interlayering of smectite with chlorite or sericite. However, the amount of such interlayering must be small or irregular as it does not show on $\underline{X}$-ray diffractograms, or as $\mathrm{Mg}$ or $\mathrm{Fe}$ in the microprobe analyses. Many of the sericite and chlorite crystals are fine grained, and some of the inhomogeneity may be due to beam overlap with other phases. This was monitored as carefully as possible by checking the energy spectrum of each spot analyzed. Small amounts of overlap and of intergrowths of other phases, however, might go undetected.

Sericites from Roosevelt in general exhibit considerably greater. heterogeneity of composition than do sericites from Southwest Tintic. The Roosevelt sericites are also fine grained, and occur in rocks with less intense alteration than at Southwest Tintic. A possible explanation for the greater compositional inhomogeneity of fine grained sericites in less altered rocks is provided by Page and Wenk 
(1979) who studied alteration products of plagioclase in the selvedge of a vein at Butte with a transmission electron microscope. They observed that sericite contains layers of other phases. Unit cell thick layers of minerals such as smectite or chlorite often occur somewhat regularly spaced 20 to 50 angstroms apart in the sericite. Small patches of other minerals, such as kaolinite or quartz, also occur in sub-micron sized zones, beneath the limit of probe beam resolution. The presence of such fine grained phases will have an effect on the analyzed compositions and homogeneity of sericite. Although X-ray diffractograms of clay separates from Roosevelt samples used for microprobe analyses do not show the presence of mixed layering in the illites, small amounts may exist. An example of mineral inhomogeneity is depicted on Figure 3 in which horizontal and vertical bars represent one standard deviation.

\section{Sericite Chemistry}

The Roosevelt Hot Springs hydrothermal system is a fracture controlled system with relatively little recrystallization of the original rock compared to many well-known mineralized hydrothermal systems. For comparison with the Roosevelt system, analyses of sericite (Figure 4 and Appendix I) from the strongly altered and recrystallized, but subeconomic, Southwest Tintic porphyry copper system were analyzed.- Also included for comparison are sericite analyses from the Santa Rita porphyry copper deposit (D. C. Jacobs, personal communication), presented in Appendix II and Figure 5.

In well 14-2 at Roosevelt alteration intensity and assemblages 


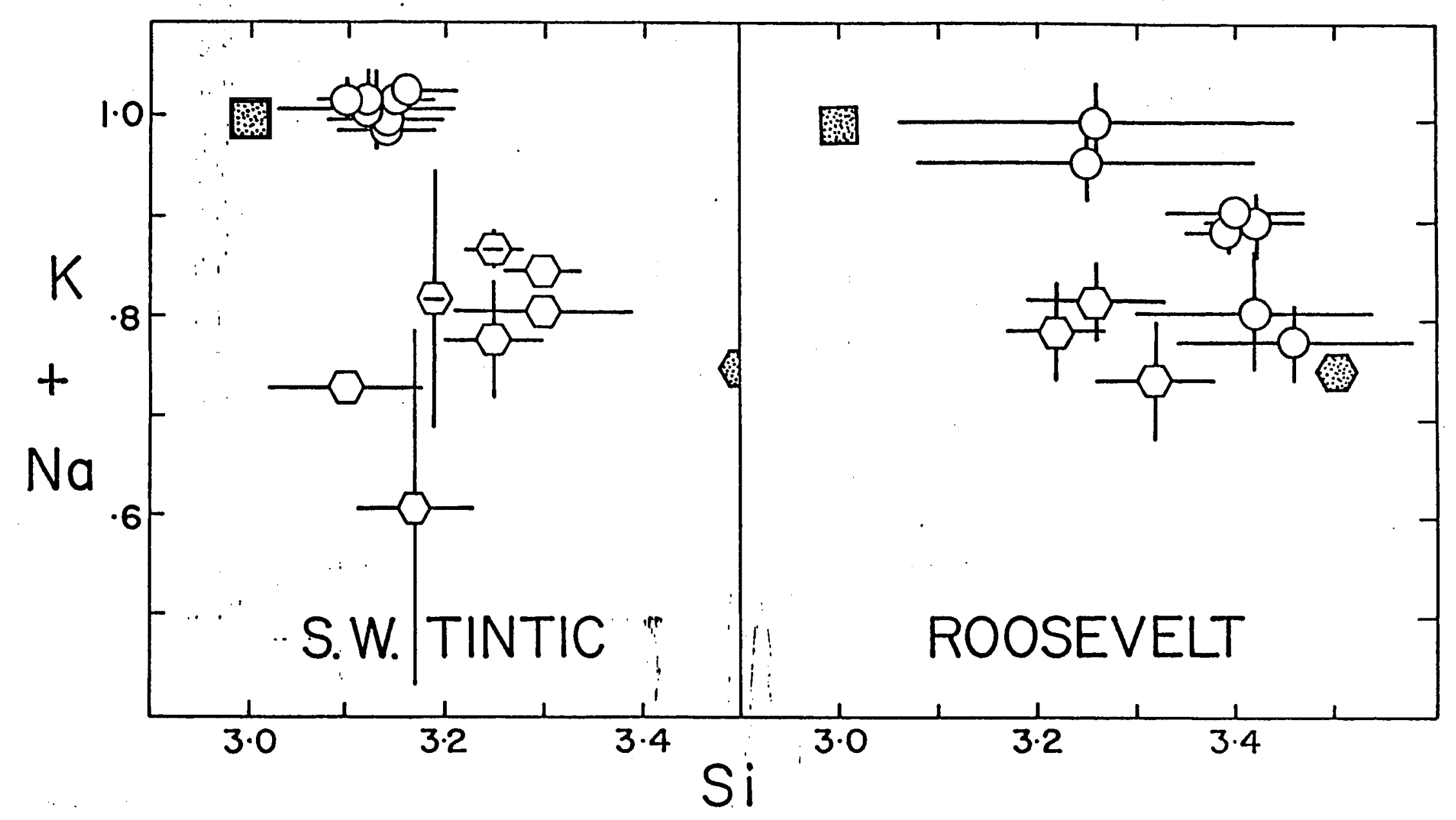

Figure 3. Compositional heterogeneity in sericites: an example. Southwest Tintic samples 5 (circles) and 6 (hexagons), Roosevelt samples 610 (circles) and 869 (hexagons). Bars represent one standard deviation on composition of individual crystal or aggregate. Shaded square and hexagon represent ideal muscovite and illite respectively. 
SOUTHWEST TINTIC

si

AIII

$\mathrm{Fe}$

$M g$

K

$\mathrm{Na}$

$\mathbf{F}$

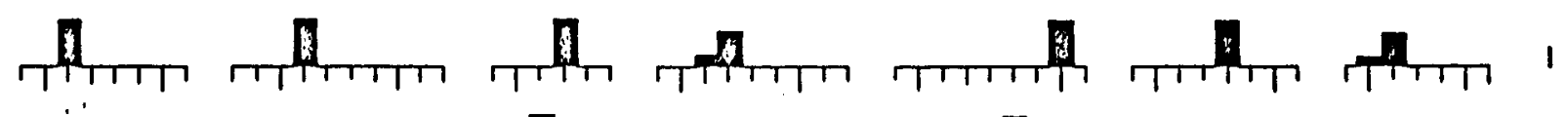
2

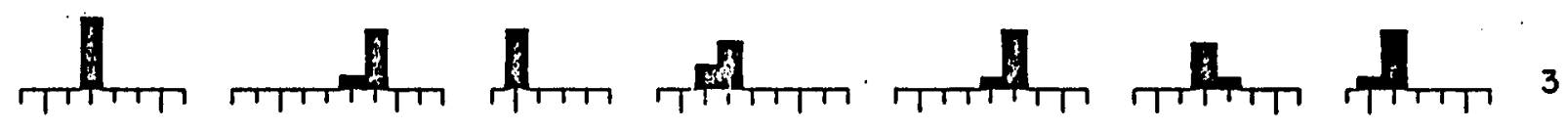
4

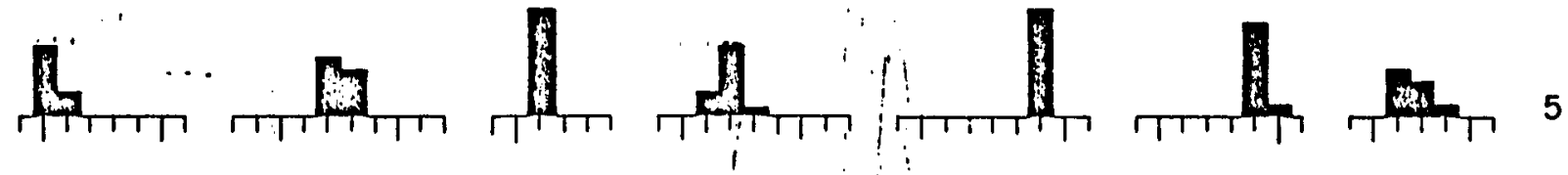
6

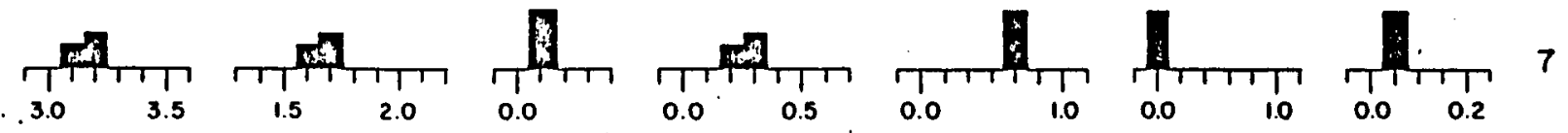

Figure 4. Element distribution in serici,te, Southwest Tintic, Utah. Numbers of ions per half unit cell. 


\section{SANTA RITA}

$\begin{array}{llllllll}\text { Si } & \text { Al } \text { II } & \text { Fe } & \text { Mg } & K & \text { No } & F\end{array}$

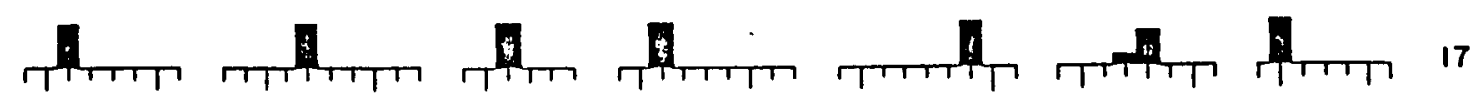
$\therefore$

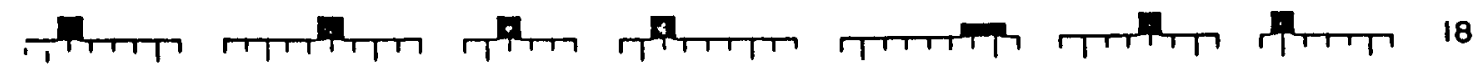

20

21

. . " 50

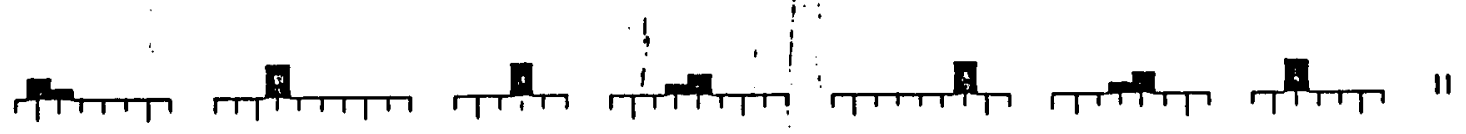

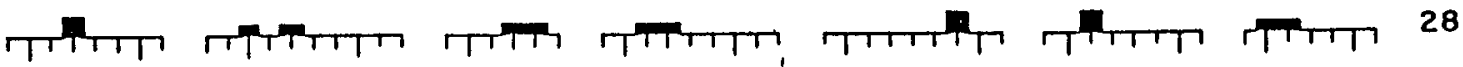

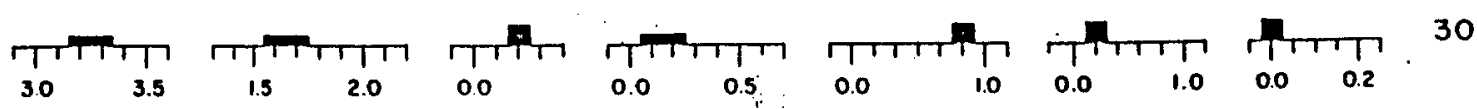

Figure 5. Element distribution in sericite, Santa Rita, New Mexico. Numbers of ions per half unit cell. 
differ at different depths in the well and appear to be related to fracture intensity, distance from fluid-bearing veins and to temperature. Intensity of alteration is most evident in the amount of plagioclase destruction. Three zones of intense alteration are recognized: 274 to $305 \mathrm{~m}, 488$ to $581 \mathrm{~m}$ and 869 to $899 \mathrm{~m}$. The last two zones correlate with temperature increases in well logs and are considered to surround hot water entry zones (Bamford, 1978, Bamford et al., 1980, Glenn and Hulen, 1979). Pervasive alteration mineralogy in any one sample varies from chip to chip, and each chip or grain may not have all of the alteration products ascribed to that sample.

Sericite is the main plagioclase replacement product, occurring with fine disseminated hematite in the upper portion- of the well, and in less abundance, often with calcite and chlorite, at depths belowi. the limit of hematite stability. Sericite also replaces hornblende above $792 \mathrm{~m}$, and occasionally occurs as stringers cross-cutting K-feldspar or quartz grains. Sericite does occur as a vein filling but is difficult to recognize in cuttings samples. Sericite tends to be fine grained, often only a few microns in size, and when fine grained may be intermixed with chlorite or other phases, making resolution and analysis difficult or impossible.

The distribution of major elements in sericite from Well 14-2 is shown in.Figure 6_and presented in Appendix III (this report) and Table 6 of Ballantyne (1978). An overall increase in Si, K, and sum of interlayer cations, and a decrease in total $A 1$ and sum of octahedral cations occurs with increasing depth in the well. $\mathrm{Fe}, \mathrm{Mg}$, octahedral Al and $\mathrm{Na}$ all fluctuate. Samples 503, 854, 869 and 896 are 


\section{ROOSEVELT HOT SPRINGS}

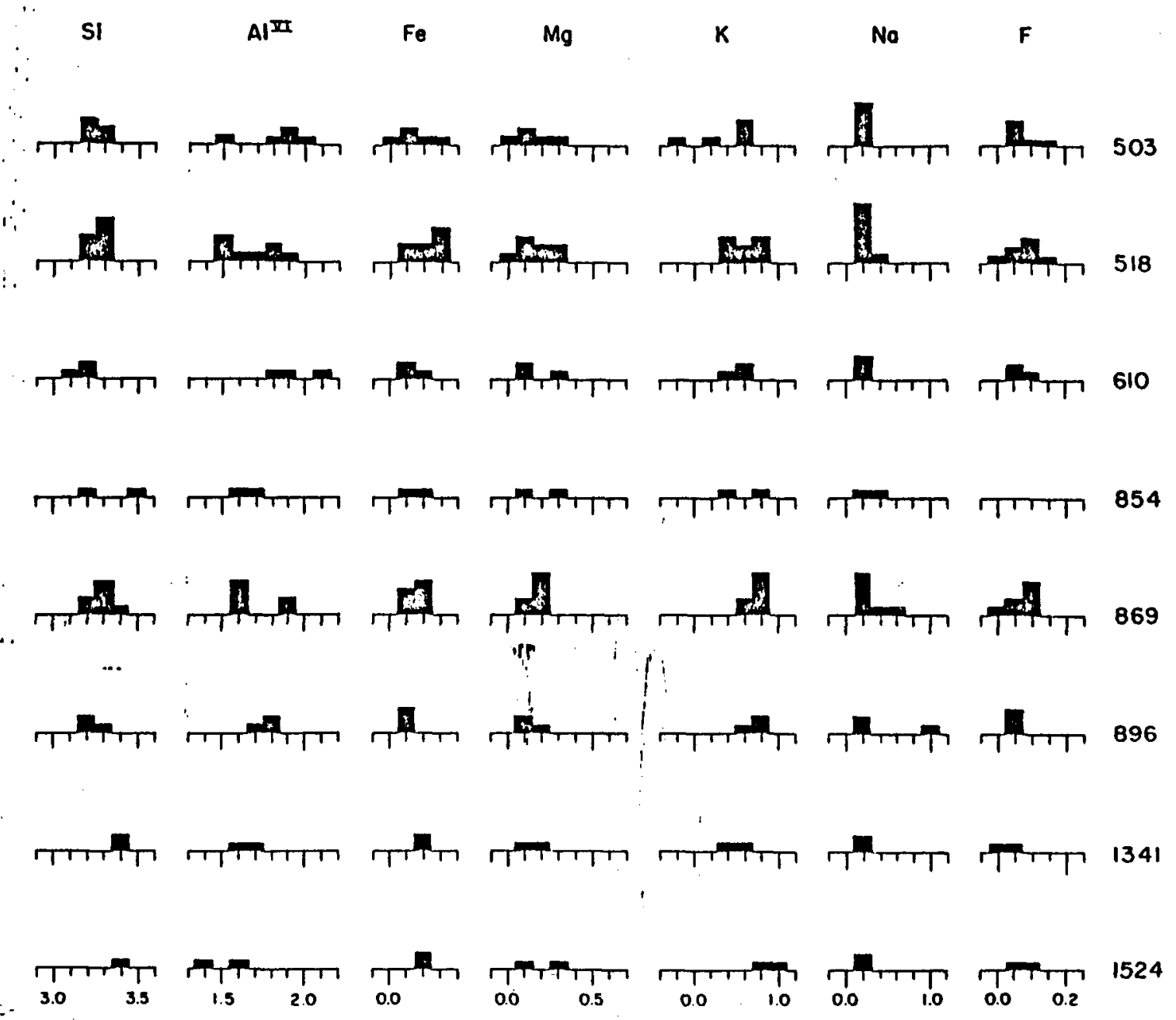

Figure 6. Element distribution in sericite, Well 14-2, Roosevelt Hot Springs, Utah. Numbers of ions per half unit cell. 
near hot water entry zones at approximately 500 and $870 \mathrm{~m}$ and do not differ significantly from other samples. Four samples, those from $503,518,610$ and $854 \mathrm{~m}$ appear to have two distinct populations of sericite. For the first three samples the difference is evident in: total Al and for the octahedral cations $\mathrm{Al}, \mathrm{Fe}$, and $\mathrm{Mg}$. Sample 854 also shows two populations of $\mathrm{Si}, \mathrm{K}$ and $\mathrm{Na}$ content. The presence of two populations may have several explanations: 1) they may indicate the presence of more than one hydrothermal event at different times in the past, 2) they may be due to sampling bias, samples being close to and distant from veins, or 3) they may represent cuttings from different depths in the well. Core is not available at these depths and the data does not provide evidence to favor any one possibility.

A plot of $\mathrm{Si}^{4+}$ vs $\mathrm{K}^{+}+\mathrm{Na}^{+}$for sericites from Roosevelt Well 14-2 (Figure 7) shows distinct populations for each alteration assemblage and shows a reciprocal relationship between $\mathrm{K}^{+}+\mathrm{Na}^{+}$and $\mathrm{Si}^{4+}$ only for the chlorite-calcite-sericite-pyrite assemblage. Sericites from individual samples span almost the compositional range of the entire set for each assemblage. In the chlorite-calcite-sericite-pyrite assemblage the variation is probably a function of distance from fluid-bearing veins and hence also of reaction progress. In the sericite-hematite assemblage, low interlayer occupancy may be due to interlayering of smectite or possibly pyrophylite components or to sub-micron sized intergrowths of other phases such as kaolinite; quartz, or feldspar. Interlayering of clays appears in X-ray diffractograms of clay smears in the upper portion of the well, but is not seen in the intervals sampled for microprobe analysis. 


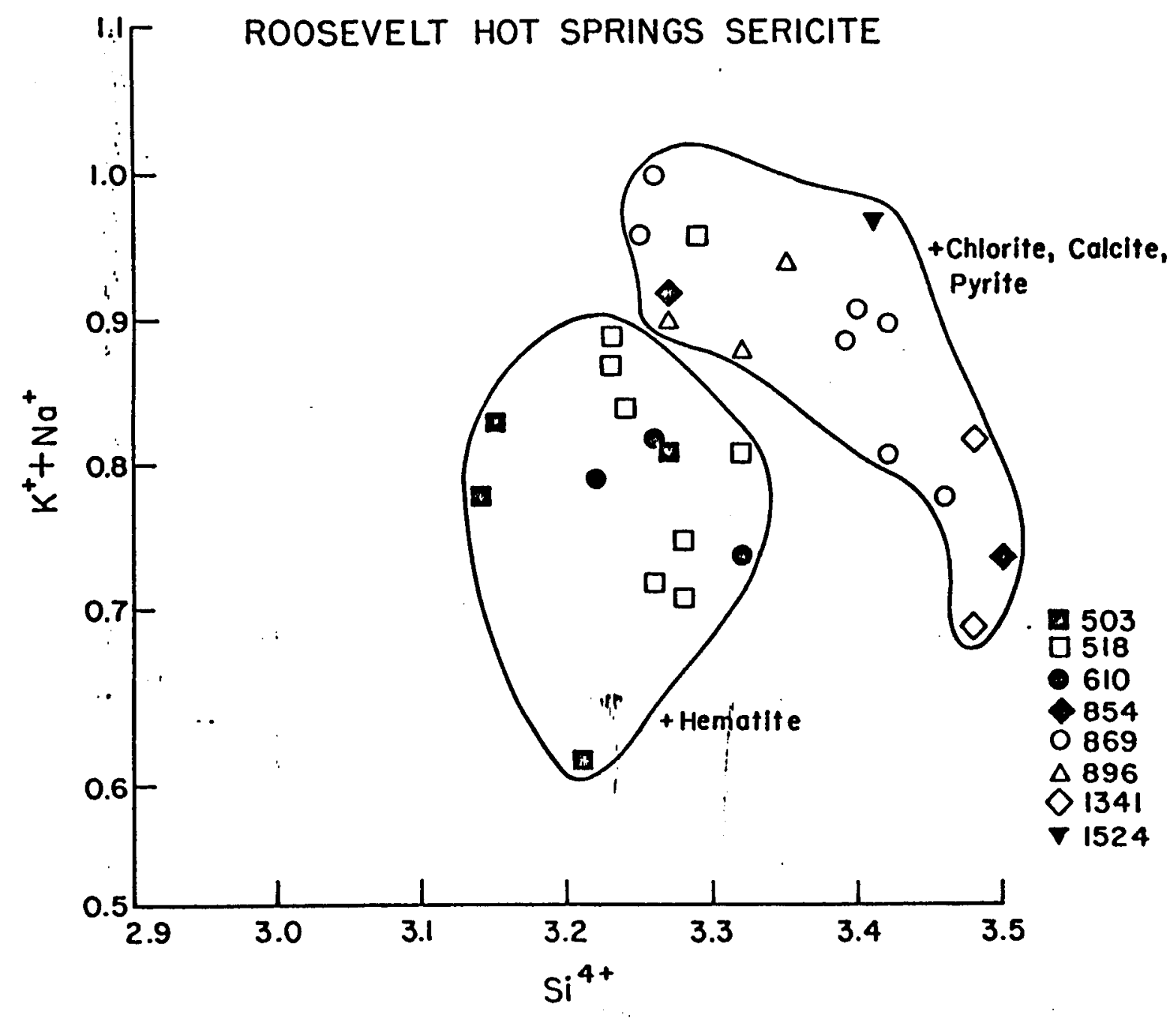

Figure 7. Interlayer vs tetrahedral site occupancy in sericite, We11 14-2, Well 14-2, Roosevelt Hot Springs. 
Octahedral site occupancy for Roosevelt sericites is shown in Figure 8. Wide variations in all three elements $\mathrm{Al}, \mathrm{Fe}$ and $\mathrm{Mg}$ exist, but the ratio $\mathrm{Mg} / \mathrm{Fe}$ remains relatively constant and near $1 . \mathrm{Mg}$ content correlates positively with F-(Figure 9). There appears to be no relationship to depth, temperature or hot water entries, as wide ranges in chemistry exist within samples.

An aspect of the effect of alteration assemblage on sericite chemistry is shown in Figure 10, which depicts sericites from well 14-2. The coexistence of chlorite allows an increased range in Si content, restricts the range of $\mathrm{Mg}$, and places a constraint on the Mg:Si relationship such that charge deficiencies generated by extra $\mathrm{Mg}^{2+}$ substitution are balanced by extra $\mathrm{Si}^{4+}$. When chlorite is absent, charge deficiencies due to $\mathrm{Mg}$ are balanced by a non-systematic combination of increases in $\mathrm{Si}^{4+}$ and in octahedral and interlayer site occupancy.

At Southwest Tintic pervasive recrystallization of the rock has taken place in most cases. The fragmental nature and fine grained matrix of the tuffs appears to have enabled ready access to and reaction with hydrothermal solutions. Sericites are relatively coarse grained, usually ten to several tens of microns across, although finer grained material is also common, particularly in propylitized rocks. Host minerals for: sericite are often difficult to ascertain. Rock groundmass appears to be volumetrically :the main reactant, and phenocrysts are also replaced. Sericite is common as a pervasive alteration product, in vein selvedges, and as vein fillings. Coexisting phases have been described in the alteration section. 


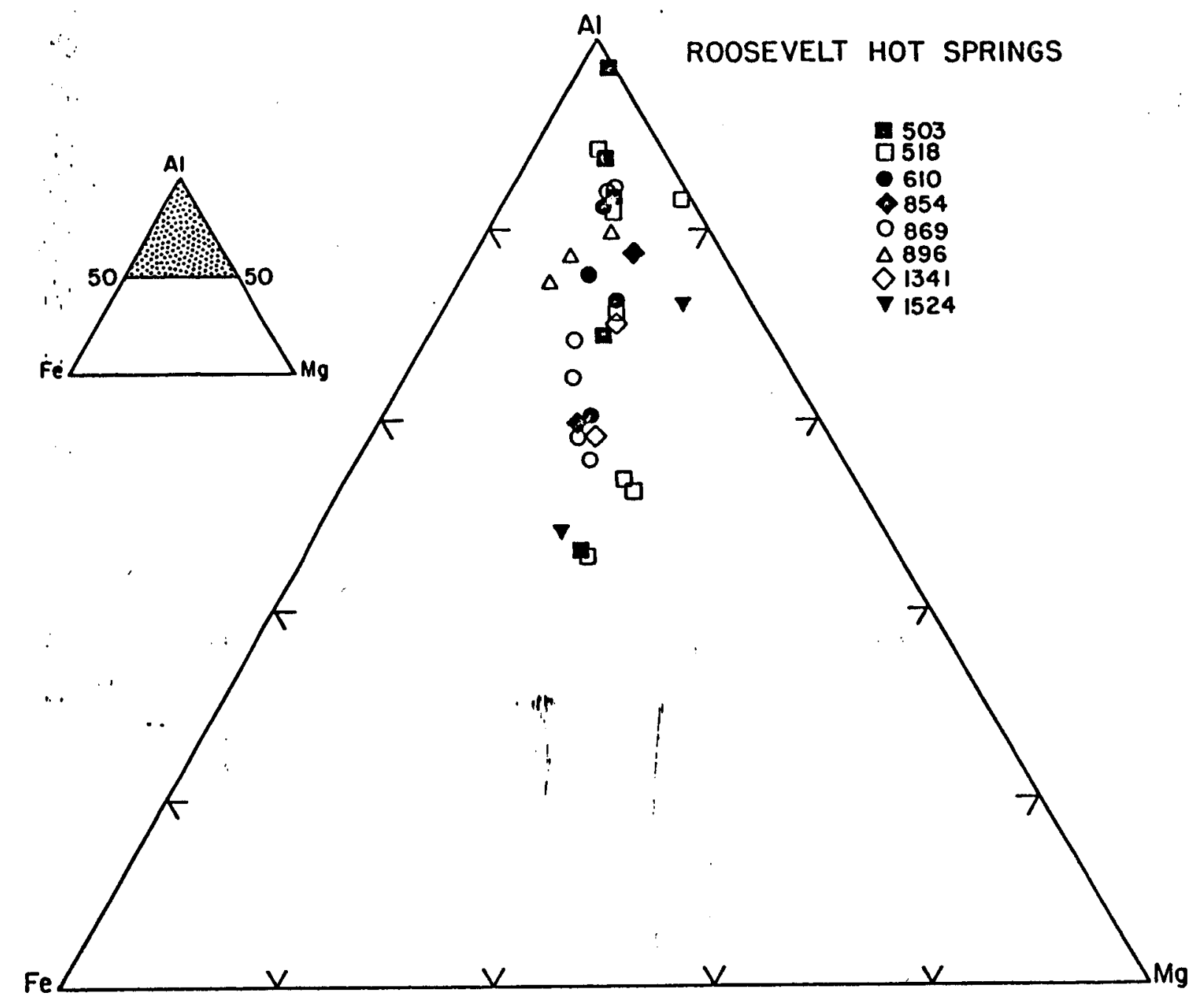

Figure 8. Octahedral cation distribution in sericite from Well 14-2, Roosevelt Hot Springs. 

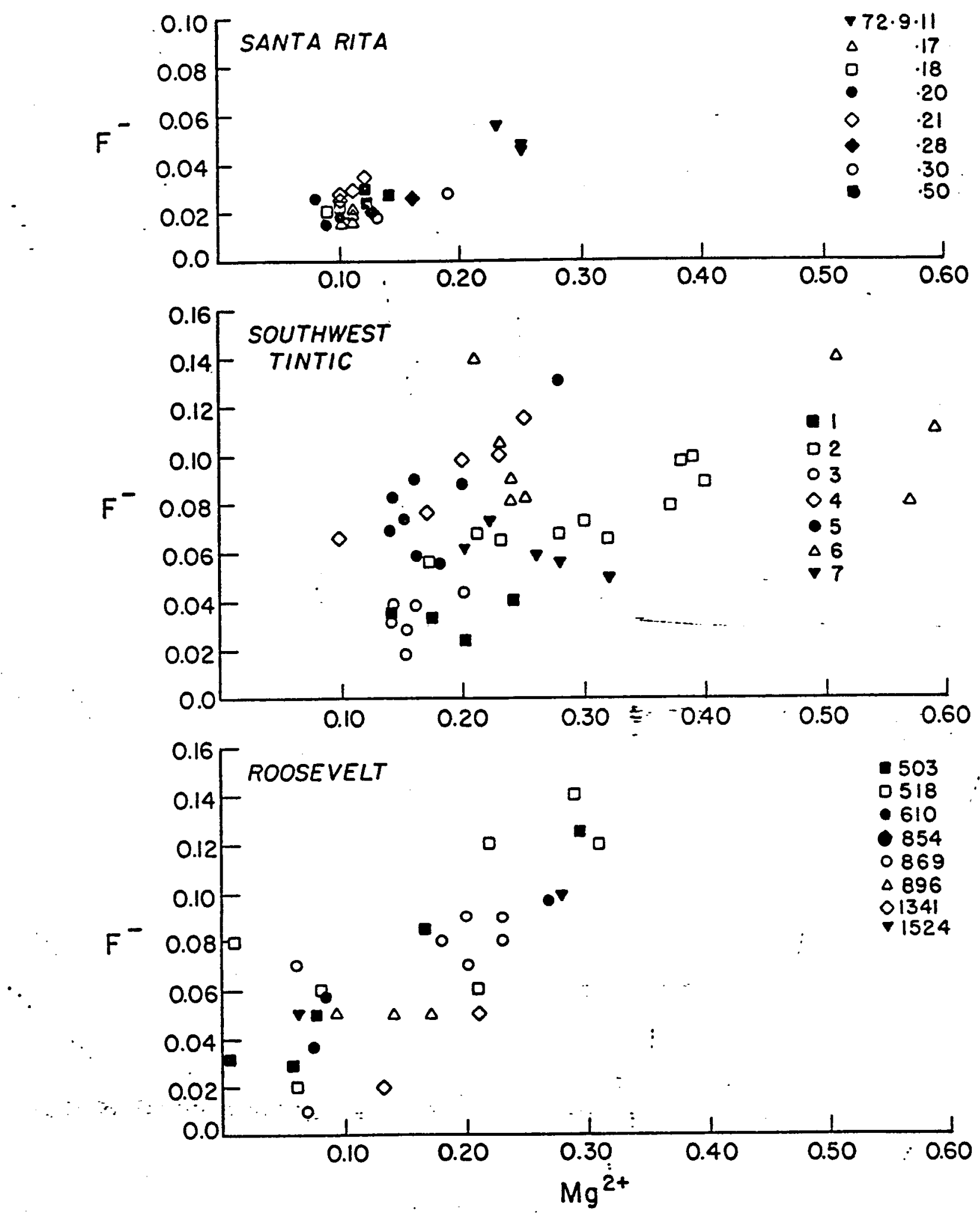

Figure 9. $\mathrm{Mg}^{2+}$ vs $\mathrm{F}^{-}$relationship in sericite from three hydrothermal systems. 


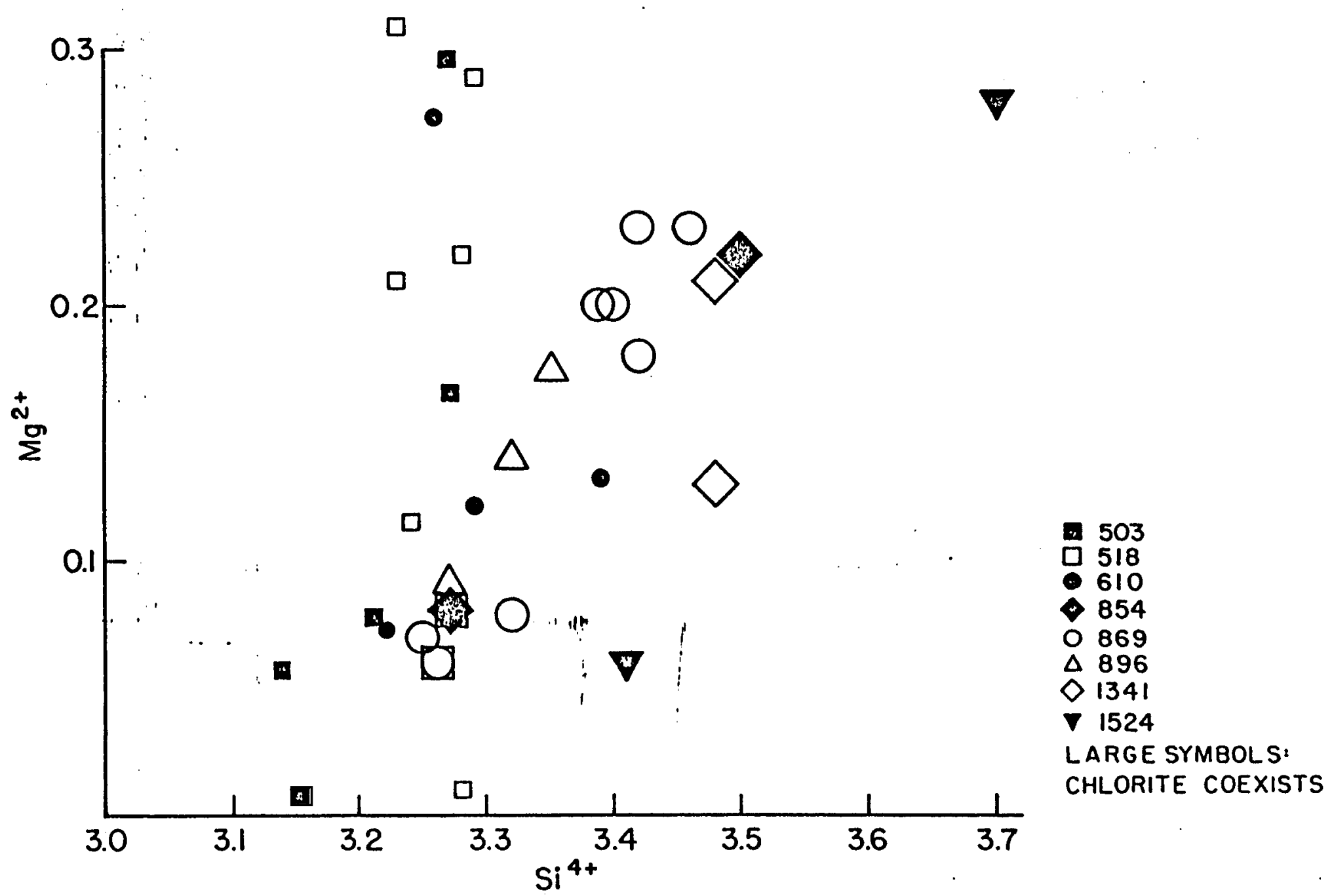

Figure 10. Effect of alteration assemblage on sericite in Well 14-2, Roosevelt Hot Springs. Samples 503,518 and 610 have, a sericite-hematite assemblage, the remainder a chlorite-sericite-calcite-pyrite assemblage. 
Compositions of Southwest Tintic sericites are shown in Figure 4. Sericites from individual samples tend to be quite homogeneous and differences between samples are often distinct, particularly in the case of octahedral and interlayer cations.

$\mathrm{Si}^{4+}$ vs $\mathrm{K}^{+}+\mathrm{Na}^{+}$for Southwest Tintic sericites (Figure 11) differs according to alteration assemblage. Four assemblages are recognized, three of which correlate moderately closely with the potassic, phyllic and propylitic assemblages of Lowell and Guilbert (1970). In these three there is a progressive decrease in muscovite-like, and a progressive increase in illite-like character from the potassic through the phyllic to the propylitic zone, also the likely direction of temperature decrease. Samples No. 2 and 5 , and the rock matrix sericites from sample 6 also have high $\mathrm{Mg}$ contents (.31 \pm .08 and $.56 \pm .04$, respectively) compared to the other samples, $\left(.19 \pm .04\right.$ for sample No. $1, .16 \pm .02$ for ${ }^{*}{ }_{0} . \overline{3}, .19 \pm .06$ for No: 4 , $.18 \pm .04$ for No. $5, .23 \pm .02$ for vein sericites from No. 6 , and .25 \pm .04 for No. 7). Sericites from sample No. 5 , however, do not have a high Mg content. Colorless chlorite coexists with those sericites having low silica and low interlayer site occupancy. That the low values might be due to interlayering of chlorite with sericite is considered unlikely because such interlayering would increase the water content, and analytical totals are already greater than $100 \%$ (Appendix I).

Octahedral occupancy in Southwest Fintic sericites is close to 2, although those high $\mathrm{Mg}$ sericites from sample No. 6 have occupancies of up to 2.3. Ford (1978) reports sericites from Panguna with similarly 


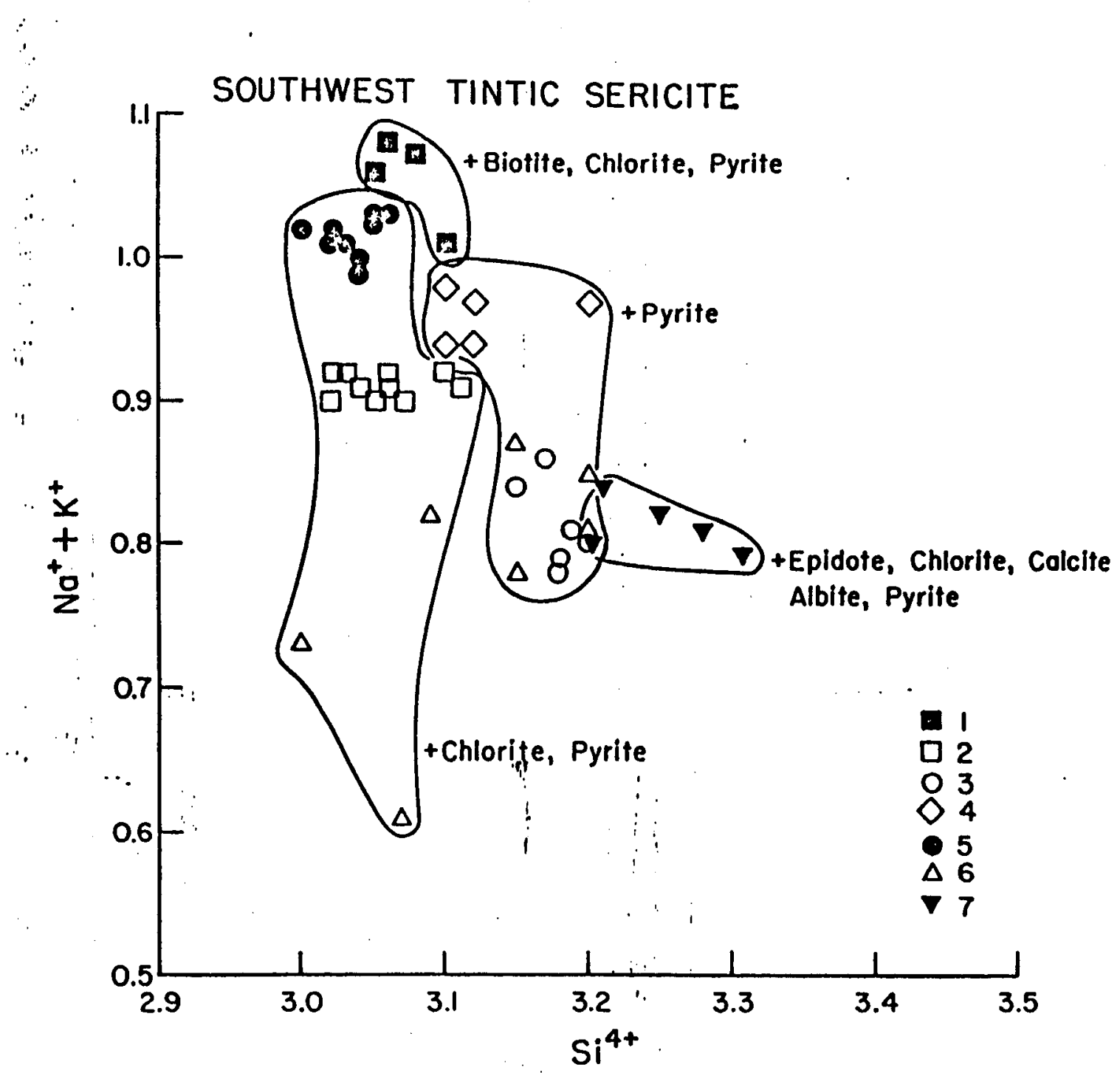

- Figure "11. Interlayer vs tetrahedrai site occupancy in sericite, Southwest Tintic. 
high octahedral site occupancy, and Guilbert and Schafer (1978) find that sericites from porphyry base metal deposits are not strictly dioctahedral. This variation in site occupancy has a small effect on the positions of points in Figure 12. Within any one sample the Fe content is relatively constant, although it differs between samples. Within a sample, however, Al-Mg substitution varies considerably. In sample No. 6 low Mg sericites from a quartz-sericite vein contrast strongly with high $\mathrm{Mg}$ sericites from the sericite-quartz-pyritechlorite assemblage in the adjacent rock matrix. A broadly positive relationship between $\mathrm{Mg}$ and $\mathrm{F}$ - content is evident for Southwest Tintic. On an individual sample basis, the correlation is stronger for samples No. $2,3,4$, and 5 , negative for No. 7, and negligible for No. 1 and 6 . Vein and matrix sericites from sample No. 6 have similar $F$ contents despite the large Mg difference. Fluorine may exchange readily with subsequent fluids while $\mathrm{Mg}$ does not.

Santa Rita sericites occur in veins, replacing biotite, and replacing plagioclase. Analyses have been kindly provided by David $C$. Jacobs. Cation contents for individual samples are shown in Figure 6 . Compositional variability is not as great as for Roosevelt and Southwest Tintic samples, possibly because only the potassic and a potassic-propylitic assemblage is represented. A plot of $\mathrm{Si}^{4+} \mathrm{vs} \mathrm{K}^{+}+$ $\mathrm{Na}^{+}$(Figure 13) shows, for those sericites coexisting with biotite and K-feldspar, a muscovite-like composition of nearly filled interlayer sites and low $\mathrm{Si}^{4+}$ content. Sericites in samples containing chlorite and epidote (but still considered potassic) have similarly high interlayer occupancy but lower $\mathrm{Si}^{4+}$. 


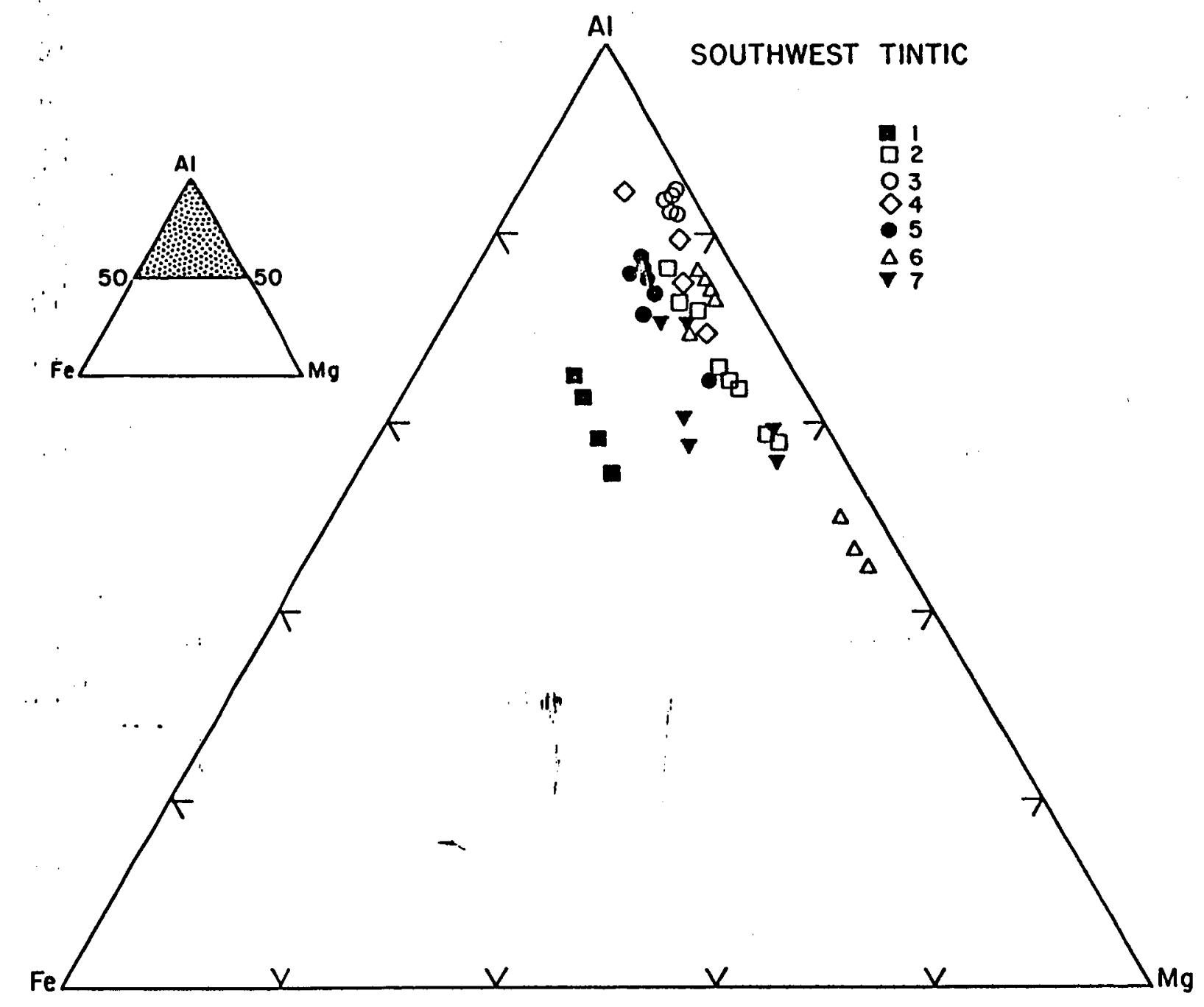

Figure 12. Octahedral cation distribution in sericite from Southwest Tintic. 


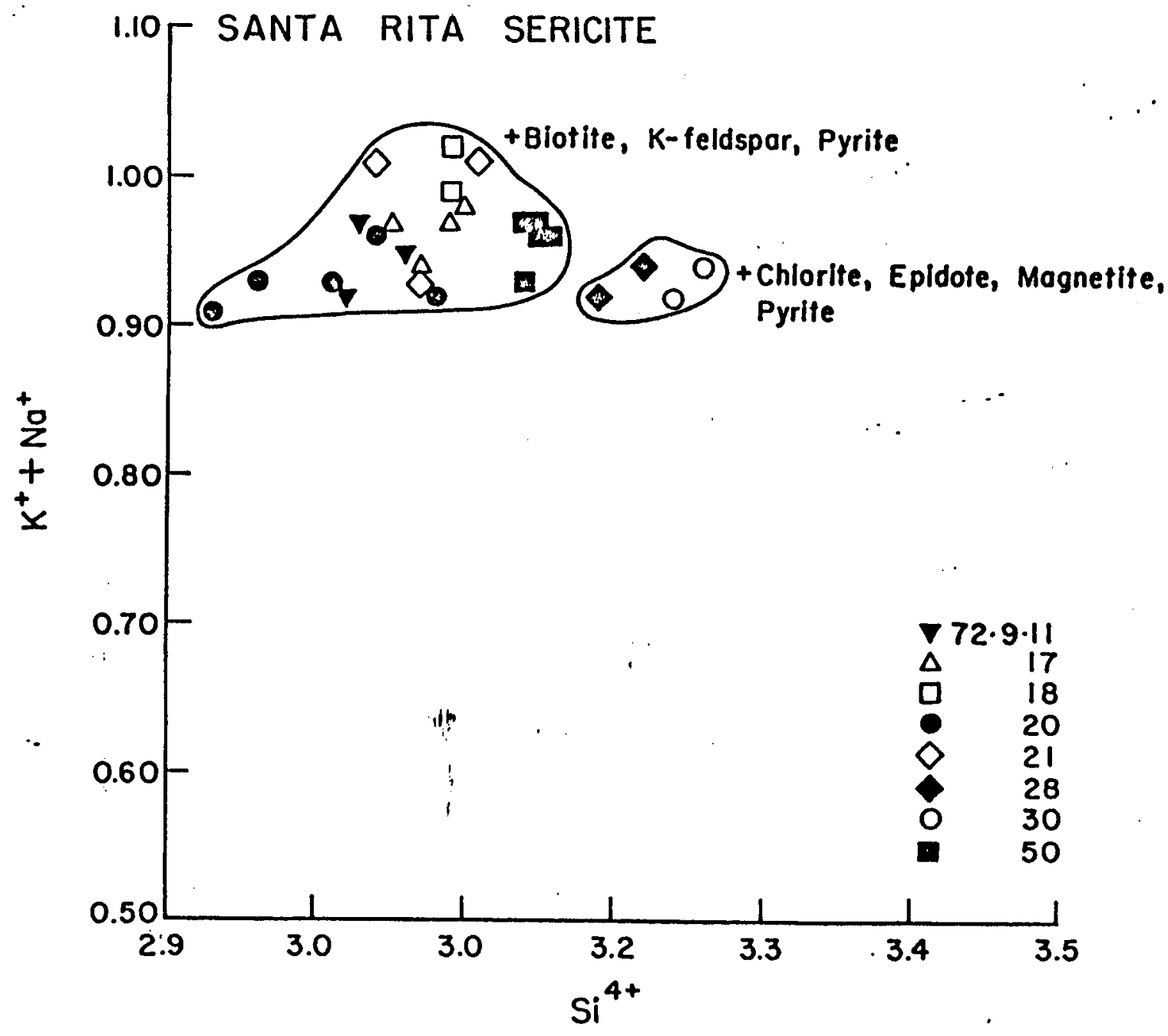

Figure 13. Interlayer vs tetrahedral site occupancy in sericite, Santa Rita. 
Octahedral sites contain relatively constant amounts of $\mathrm{Mg}$ within individual samples, and for most samples $\mathrm{Al}$ and $\mathrm{Fe}$ vary more than $\mathrm{Mg}$ (Figure 14$)$. Mg and $F$ contents vary little among the samples analyzed, and the correlation between the two is positive.

Differences in sericite chemistry in the three systems studied are particularly evident in Figure 15. Whether the chemical differences are due to differences in fluid or host rock chemistry or to pressure-temperature conditions has not been determined. Potassic zone sericites appear to be muscovitic in character, propylitic zone sericites are more like illites, and those sericites with associations relating more closely to phyllic assemblages fall somewhere between. The temperature difference between 500 and $550 \mathrm{~m}$ in Well 14-2 at Roosevelt is only about $45^{\circ} \mathrm{C}$ (Figure $2,11 / 15 / 76 \mathrm{log}$ ) and may be insufficient to cause the chemical distributions observed in other systems. Octahedral site occupancy differs in content and style in the three systems. Roosevelt sericites have relatively constant $\mathrm{Mg} / \mathrm{Fe}$ ratios and variable Al contents. Southwest Tintic sericites have nearly constant $\mathrm{Fe}$ contents but variable $\mathrm{Al}$ and $\mathrm{Mg}$. Santa Rita sericites vary more in $\mathrm{Fe}$ and $\mathrm{Al}$, although the amount of variation is less than for the other two systems (Figure 15). Figure 15 contains for comparison, data from Salton Sea Well Elmore No. 1, (McDowell, 1978) and for muscovites from Main metapelites (Guidotti, 1978).

\section{Chlorite Chemistry}

Chlorites from Roosevelt Hot Springs Well 14-2 and Southwest Tintic have been analyzed. For comparison data from Silver Bell (G. 


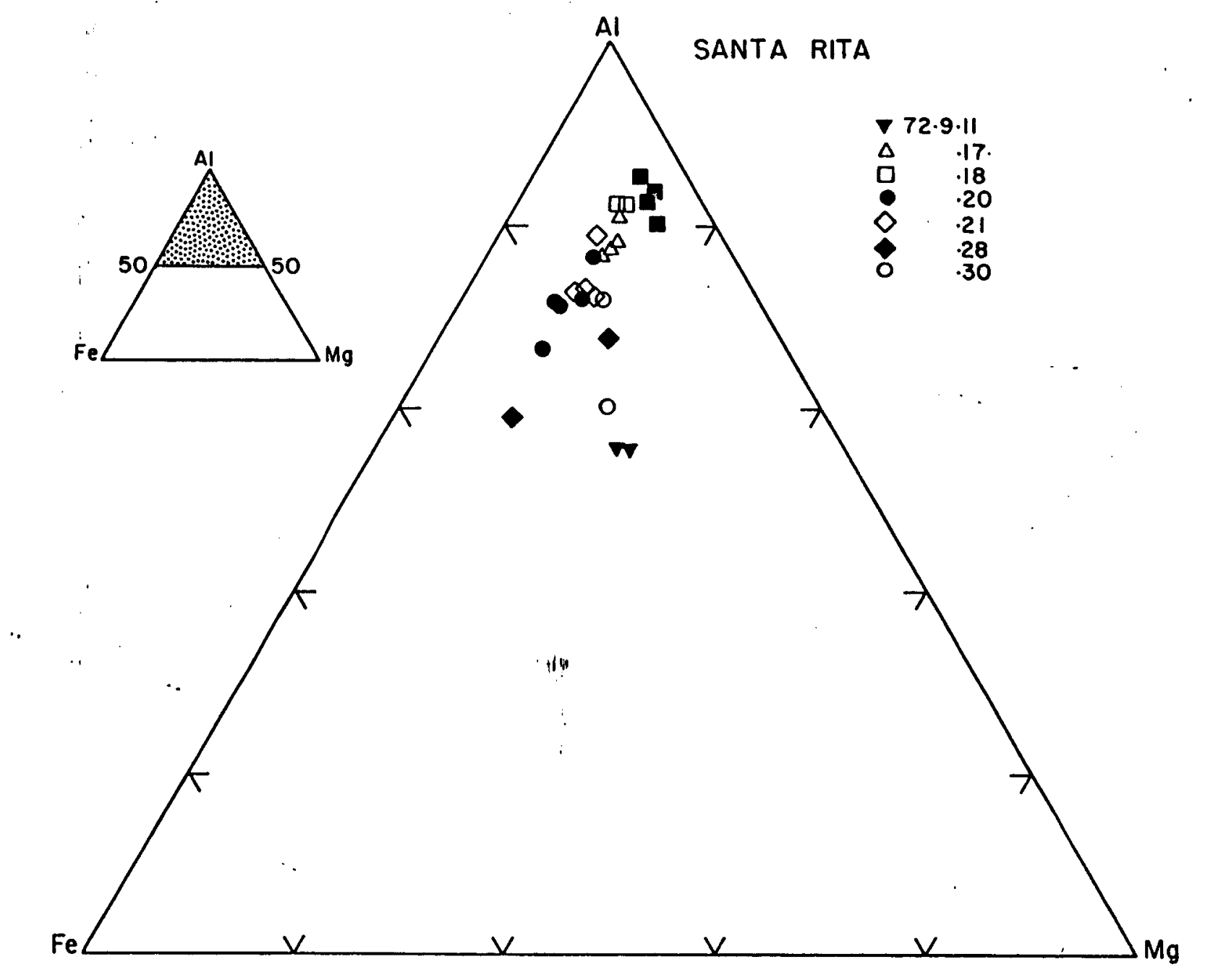

Figure 14. Octahedral cation distribution in sericite from Santa Rita. 


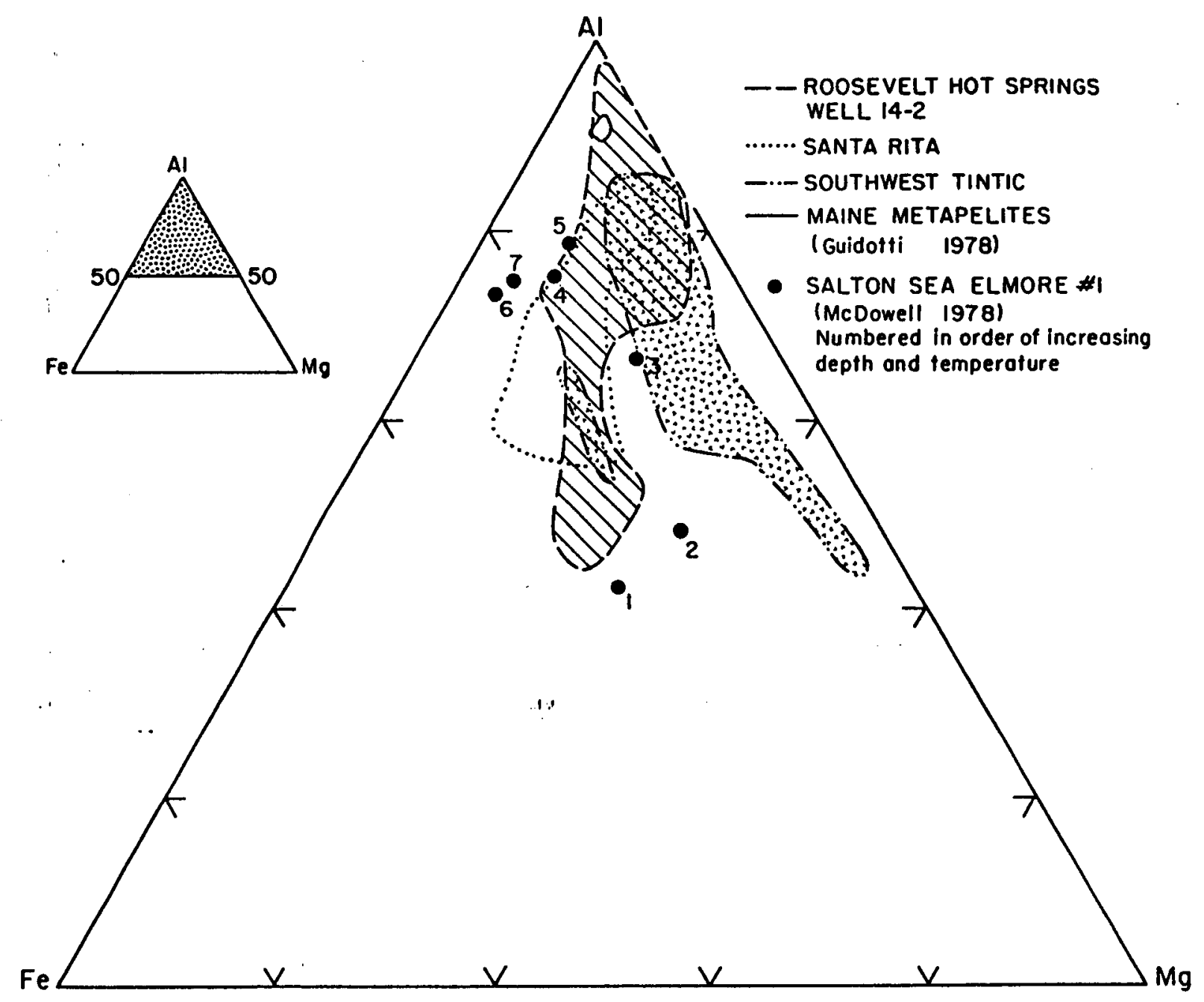

Figure 15. 0ctahedral cation distribution in sericite from 
H. Ballantyne, personal communication) and Salton Sea Well Elmore No. 1 (McDowell, 1978) have been included in one Figure.

Chlorite in Roosevelt Well 14-2 is green in color and occurs as a replacement product of biotite, hornblende and plagioclase and as a. vein filling. Chlorite replacing biotite usually pseudomorphs the reactant mineral as large, optically continuous crystals. Chlorite replacing hornblende and plagioclase is fine grained, usually less than 10 microns in size, and forms clusters and aggregates of apparently randomly oriented crystals.

Chlorite at Southwest Tintic is green in the potassic and propylitic alteration assemblages and colorless in the phyllic assemblage. Crystals are usually coarse, 10 microns or greater in size, and occur as replacements of rock material and as vein fillings. Concentrations of chlorite crystals, often radially arranged in the phyllic zone samples, are interpreted to be replacements of mafic minerals. Mineral associations have been discussed in the alteration section. Chlorite chemistry in the hydrothermal systems studied varies mainly in the amount of $\mathrm{Mg}$ and $\mathrm{Fe}$ substitution in octahedral sites. Although the quantity of Al in chlorites can vary between approximately .2 and 4.0 (Albee, 1962) the hydrothermal chlorites analyzed usually contain between 2.0 and $2.6 \mathrm{Al}^{3+}$ ions per formula unit. Chlorite analyses from Roosevelt Hot Springs Well 14-2, and Southwest Tintic, are listed in Table $1: 5$ of Ballantyne (1978) and Appendix IV of this report, respectively.

Roosevelt chlorites fall in the ripidolite, brunsvigite and pycnochlorite fields of Hey (1954) and Deer, Howie and Zussman (1966), 
having $\left(\mathrm{Fe}^{2+}+\mathrm{Fe}^{3+}\right) /\left(\mathrm{Fe}^{2+}+\mathrm{Fe}^{3+}+\mathrm{Mg}^{2+}\right)$ between 0.4 and 0.7 and $\mathrm{Si}^{4+}$ between 2.7 and 3.1 (Figure 16). The octahedral site occupancy (Figure 17) shows a major variation in $\mathrm{Mg}^{2+}$ and $\mathrm{Fe}^{2+}$ with less variation in $\mathrm{Al}$ content. The same effect is also evident in Figure 18.

Southwest Tintic chlorites are Mg-rich (Figure 16) and may be classifed as sheridanite, clinochlore, ripidolite and pycnochlorite (Hey, 1954, Deer, Howie and Zussman; 1966). The Mg-rich chlorites from samples No. 2 and No. 6 are colorless in thin section and hand specimen and are from phyllically altered samples. Octahedral site occupancy in Southwest Tintic chlorites is shown as four small fields, one for each sample in Figure 17. Note that the potassic and propylitic zone chlorites (samples No. 1 and 7) have similar octahedral site compositions, and are distinct from the two Mg-rich phyllic zone samples. Comparisons between the two hydrothermal systems show that Roosevelt and Tintic chlorites are compositionally distinct (Figures 16 and 17). Data for Salton Sea Well Elmore No. 1 (McDowell, 1978) and Silver Bell (G. H. Ballantyne, personal communication) show partial overlaps of chemical ranges for octahedral site substituton. Fluorine is present in significant amounts in many chlorites, particularly those from Southwest Tintic (Appendix IV). Chlorites from Roosevelt, and the potassic and propylitic zones at Southwest Tintic contain up to $0.1 \mathrm{~F}^{-}$ions per formula unit, and $\mathrm{F}^{-}$ contents of magnesian chlorites from the Southwest Tintic phyllic zone are 0.14 to 0.26 . 


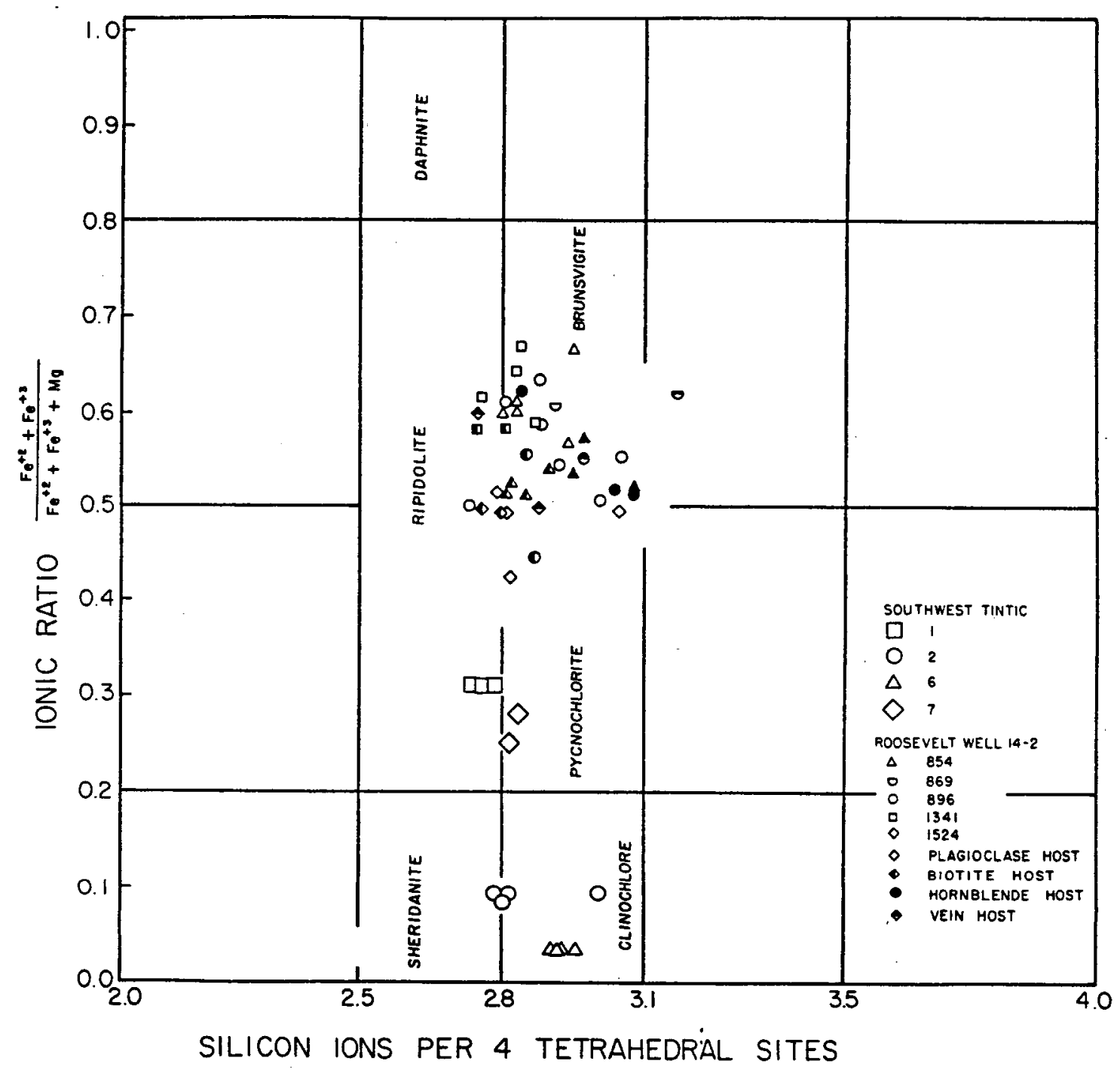

Figure 16. Chlorite composition and nomenclature. Classification After Deer, Howie and Zussman(1966) and Hey (1954). 


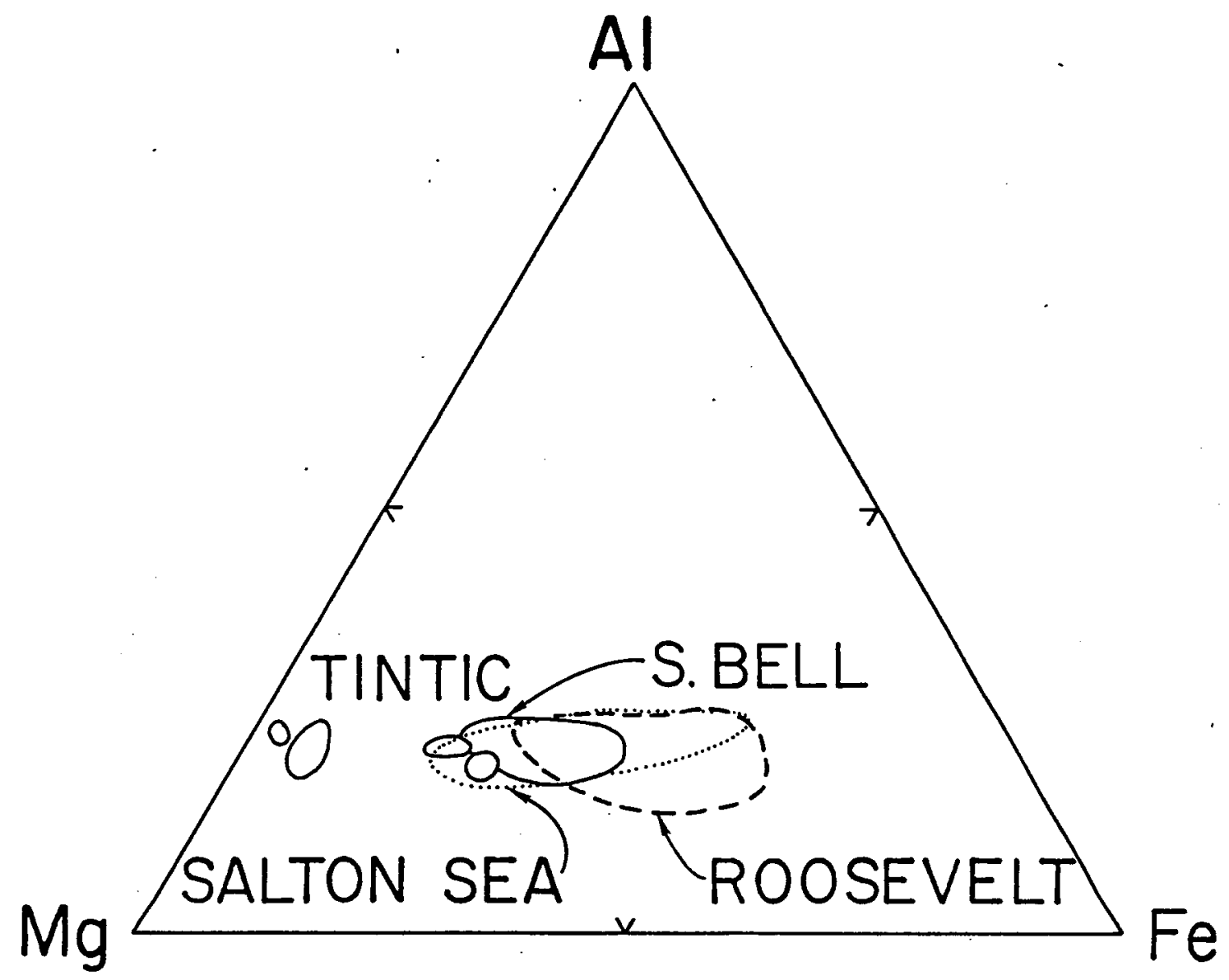

Figure 17. Octahedral cation distribution in chlorite from four hydrothermal systems: Southwest Tintic, Silver Bell, Salton Sea and Roosevelt Hot Springs. Four small areas are Southwest Tintic samples. 
Host Mineral Effect

The $\mathrm{Fe}$ and $\mathrm{Mg}$ end members daphnite and $\mathrm{cl}$ inochlore may be used to show the effect of host mineral on chlorite composition. For this calculation all $\mathrm{Fe}$ is considered to be $\mathrm{Fe}^{2+}$ and included in the daphnite end-member. There is an inverse relationship between clinochlore and daphnite for chlorites replacing biotite and hornblende, suggesting that the AIVI remains constant, but for chlorites replacing plagioclase the situation is more complex, and it appears that AlVI varies in addition to $\mathrm{Fe}$ and $\mathrm{Mg}$ (Figure 18). Host mineral effect is also discussed in Ballantyne (1978). The variation in $\mathrm{Fe}$ and $\mathrm{Mg}$ content of chlorites in individual samples may be due to variation in alteration intensity or reaction progress.

\section{Whole Rock Chemistry Effect}

Sericite chemistry does not appear to reflect whole rock chemistry in any way that can be easily determined. However chlorite chemistry appears to be affected by whole rock $\mathrm{Fe}$ and $\mathrm{Mg}$. Roosevelt sample 1341 has a considerably lower whole rock $\mathrm{Fe}$ and $\mathrm{Mg}$ content than the other chlorite bearing samples (Parry, 1978). Chlorites from this sample are particularly Fe-rich compared to other samples, and the whole rock $\mathrm{Mg}$ content is lower than for other samples.

Whole rock analyses from Southwest Tintic have not been completed for those samples in which alteration minerals have been analyzed. However, 24 samples of pyroclastic and flow material from outside the mineralized system appear to be similar to host rocks within the system, and are more $\mathrm{Mg}$ - and Fe-rich than those from Roosevert. 

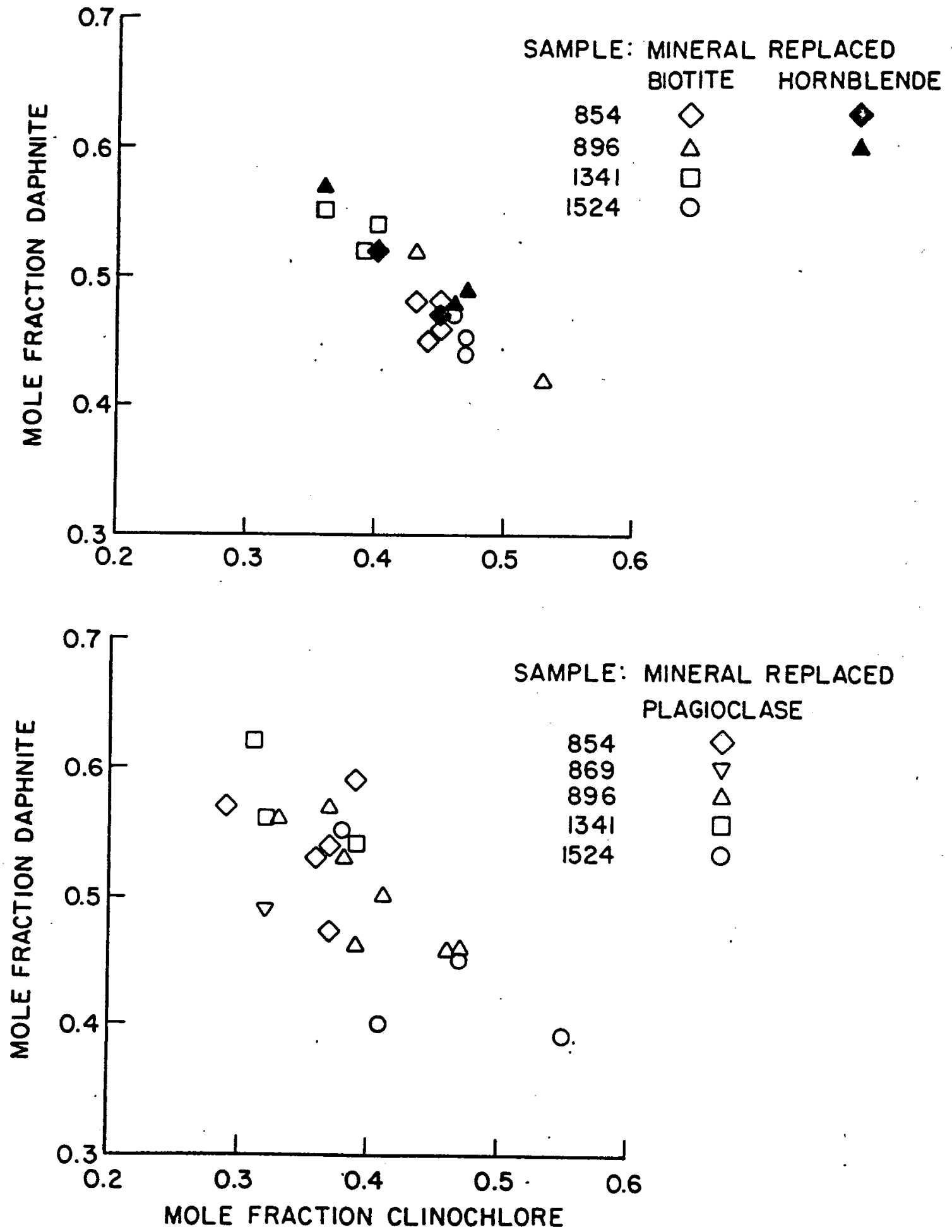

Figure 18. Effect of host mineral replaced on chlorite composition, Well 14-2, Roosevelt Hot Springs. 
Southwest Tintic sericites and chlorites are more magnesium-rich than those from Roosevelt.

\section{Coexisting Sericite and Chlorite}

The relationship between octahdral cations of coexisting sericite-chlorite pairs can be used to determine whether or not equilibrium has been attained between alteration minerals. Coexisting sericite and chlorite from Roosevelt Hot Springs Well 14-2 and from Southwest Tintic are shown in a triangular Fe-Mg-AlVI diagram in Figure 19. Tie lines for the four Southwest Tintic samples are parallel and almost coincident within individual samples, suggesting an equilibrium situation. Four samples from Roosevelt however exhibit crossing tie lines and are apparently not near equilibrium with one bulk geothermal fluid. The Roosevelt sericites and chlorites included in Figures 19 and 20 are fine grained and replace plagioclase, whereas those from Southwest Tintic are coarser grained and occur as rock matrix replacements and vein fillings.

Partitioning of elements between coexisting sericite-chlorite pairs for Southwest Tintic and Roosevelt is shown in Figure $20 . \mathrm{Si}^{4+}$ and octahedral cation contents are shown. Except in the case of AiVI, data from the two systems plot in different. regions on each graph. The partitioning for $\mathrm{Si}^{4+}$ falls into two groups, 1) the biotite and epidote-bearing samples from Southwest Tintic (i.e., from the propylitic and potassic assemblages) and the propylitic assemblage at Roosevelt, and 2) an assemblage more phyllic in character in which Si partitions more strongly into the chlorite. Octahedral cations 


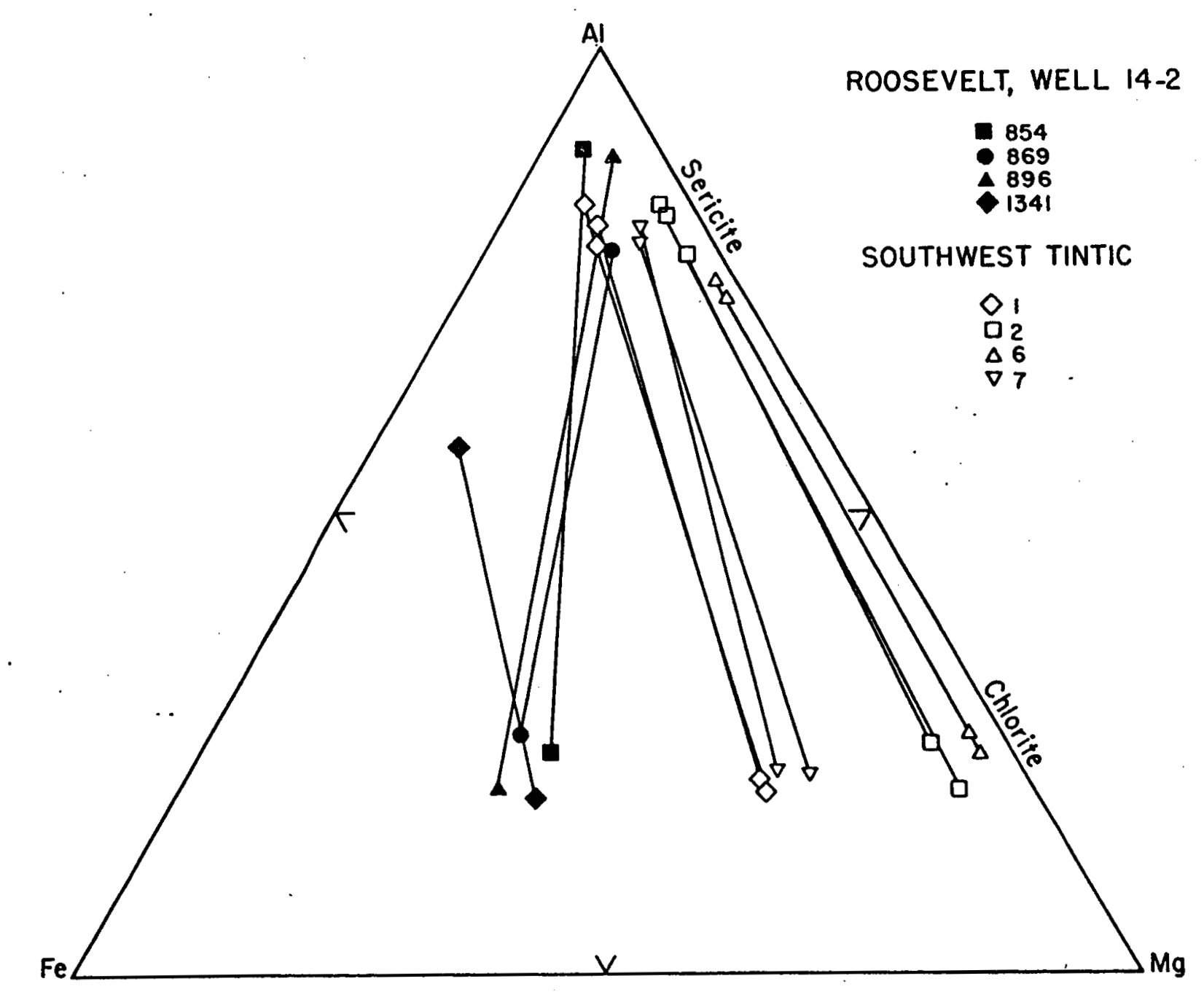

Figure 19. Octahedral cation distribution in coexisting sericite and chlorite. 

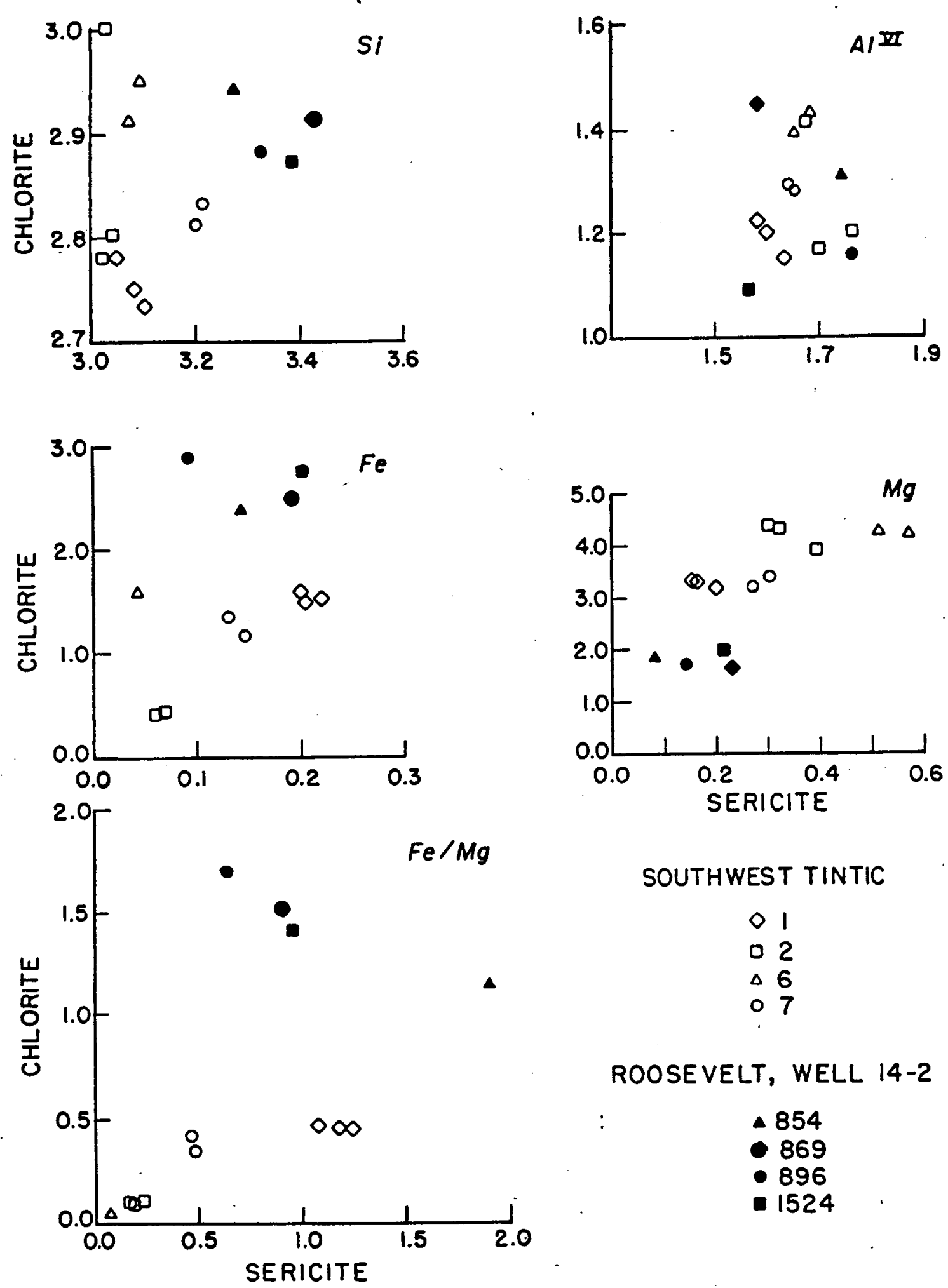

SOUTHWEST TINTIC

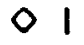

० 2

$\triangle 6$

० 7

ROOSE VELT, WELL 14-2

- 854

- 869

- 896

- 1524

Figure 20. Elcment partitioning in coexisting sericite and chlorite. 
exhibit a more diffuse pattern. AlVI varies quite widely even within Southwest Tintic samples. $\mathrm{Fe}$ and $\mathrm{Mg}$, however, show more consistent patterns. Three samples from Southwest Tintic have a similar partition function, while in the fourth (No. 6) and the Roosevelt samples, Fe partitions more strongly into the chlorite. The Mg relationship is, in a sense the reciprocal of the fe relationship at Southwest Tintic. Samples which have Fe more strongly partitioned into chlorite have $\mathrm{Mg}$ more strongly partitioned into sericite. This reciprocal relationship does not hold for Roosevelt. The $\mathrm{Fe} / \mathrm{Mg}$ ratio has a constant partition relationship in three of the Southwest Tintic samples, with the fourth, potassic zone, sample (No. 1) having Fe/Mg partitioned toward sericite. The Roosevelt samples exhibit a range of values. 


\section{THERMODYNAMIC INTERPRETATION}

The objective of this research has been to determine whether sericite and chlorite chemistry can be used as an exploration indicator in geothermal environments. In addition to characterizing mineral compositions in both a geothermal and several porphyry copper systems the following problems have been considered: 1) determination of whether equilibrium has been attained between fluid and minerals, 2) an explanation of the control of host mineral type on alteration mineral chemistry, 3) examination of the sensitivity of alteration mineral chemistry to changes in fluid composition and temperature, and 4) modeling of a hypothetical fluid in equilibrium with observed sericite-chlorite pairs at Roosevelt.

Attainment of Equilibrium

Several lines of evidence indicate that overall equilibrium between alteration minerals and bulk geothermal fluid has not been attained at Roosevelt. Some of the alteration may have resulted from other hydrothermal fluids. Mineral chemistry is inhomogeneous on the scales of both individual grains or aggregates, and of individiual cuttings samples. Host mineral affects chlorite chemistry. Additional evidence is given by the partitioning of octahedral cations between sericite and chlorite (Figure 19) where tie lines between minerals cross. Lack of equilibrium at Roosevelt is at least partly due to the fracture controlled nature of the fluid flow and hence of the distribution of alteration. Fluid moves away from fractures through the rock, reacting with pre-existing minerals and changing in 
composition. A semiquantitative measure of the changes in composition of hydrothermal sericite with increasing distance from a vein is presented by Page and Wenk (1979). Using a transmission electron microscope and attached energy dispersive system they showed that over a distance of $10 \mathrm{~cm}$ from the vein the weight $\% \mathrm{Fe} / \mathrm{Si}$ increased from approximate mean values of 0.1 adjacent to the vein to 0.2 at a distance of $10 \mathrm{~cm}$, and that weight ratio $\mathrm{K} / \mathrm{Si}$ changed from approximate mean values of 0.4 to 0.2 over the same distance. Samples further from the vein also exhibited a wider range of values than those close to the vein. Part of the inhomogeneity may be due to fine scale interlayering of smectite or patches of other fine grained alteration phases such as kaolinite or quartz.

Oxygen isotope analyses of fluid, clay minerals, quartz and whole rock demonstrate a lack of equilibrium between the bulk geothermal fluid and alteration minerals and that clay minerals tend to retain the isotopic signature of the rock rather than obtaining that of the bulk fluid (D. Rohrs, personal communication). However, the bulk fluid is isotopically modified by interaction with the surrounding rock, and hence the modified fluid may be responsible for alteration and isotopic effects away from major fluid channelways.

Estimates of the degree of departure from equilibrium are discussed later.

Host Mineral Control on Alteration Mineral Chemistry

The different compositions of chlorites replacing different host minerals may be explained by examining reaction mechanisms. Page and 
Wenk (1979) observed a progression in plagioclase alteration products in the selvedge of a vein at Butte. Furthest from the vein, transmission electron microscopy showed embryonic smectite crystallites along cleavage traces, extending for only a few unit cells. As alteration intensity increased, the smectite appeared to be replaced first by coherent intergrowths of $10 \AA$ sericite and $7 \AA$ chlorite, and later by $14 \AA$ chlorite and $20 \AA$ mica. Guilbert and Sloan (1967) using an electron microscope also studied alteration of plagioclase to montmorillonite in Butte quartz monzonite. They noted a transition from early amorphous allophane through polygonal and wispy flakes to montmorillonite, in certain cases, while in others montmorillonite appeared to form directly from plagioclase without an intervening allophane stage. They suggested that direct conversion to montmorillonite might occur in a system with greater availability of magnesium. In different microsystems of different host minerals, slightly different reaction mechanisms may occur with differing resultant mineral chemistry, or different fluid chemistries may have caused breakdown of different host minerals.

Alteration minerals from the strongly recrystallized portions of porphyry copper systems however, appear to have equilibrated with a hydrothermal fluid. Individual samples are relatively more homogeneous than those from Roosevelt, and coexisting sericite-chlorite pairs from Southwest Tintic (Figure 19) exhibit parallel or coincident tie lines on an octahedral cation plot, suggesting equilibration with a fluid. 
Sensitivity of Mineral Composition to Fluid Composition and

Temperature

Estimates of the theoretical sensitivity of sericite and chlorite chemistry to changes in temperature and fluid composition can be made by examining the equilibrium between these minerals and low albite, in the system $\mathrm{K}-\mathrm{Na} a-\mathrm{Al}-\mathrm{Si}-\mathrm{O}-\mathrm{H}$.

Two reactions are:

A. $3 \mathrm{NaAlSi}_{3} \mathrm{O}_{8}+\mathrm{K}^{+}+2 \mathrm{H}^{+}+12 \mathrm{H}_{2} \mathrm{O}=\mathrm{KAl}_{3} \mathrm{Si}_{3} \mathrm{O}_{10} \mathrm{O}(\mathrm{OH})_{2}+3 \mathrm{Na}^{+}+6 \mathrm{H}_{4} \mathrm{SiO}_{4}$

$\log \mathrm{K}=6 \log \mathrm{a}\left(\mathrm{H}_{4} \mathrm{SiO}_{4}\right)+3 \log \mathrm{a}\left(\mathrm{Na}^{+} / \mathrm{H}^{+}\right)-\log \mathrm{a}\left(\mathrm{K}^{+} / \mathrm{H}^{+}\right)+\log \mathrm{a}$ (muscovite)

Log $K$ has a value of -2.16 at $200^{\circ} \mathrm{C}$ and -1.65 at $250^{\circ} \mathrm{C}$ using data from Helgeson (1969).

B. $2 \mathrm{NaAlSi}_{3} \mathrm{O}_{8}+14 \mathrm{H}_{2} \mathrm{O}+5 \mathrm{Mg}^{2}+=\mathrm{Mg}_{5} \mathrm{Al}_{2} \mathrm{Si}_{3} \mathrm{O}_{10} \mathrm{O}(\mathrm{OH})_{8}+2 \mathrm{Na}^{+}+3 \mathrm{H}_{4} \mathrm{SiO}_{4}+8 \mathrm{H}^{+}$ $\log \mathrm{K}=3 \log \mathrm{a}\left(\mathrm{H}_{4} \mathrm{SiO}_{4}\right)+2 \log \mathrm{a}\left(\mathrm{Na}^{+} / \mathrm{H}^{+}\right)-5 \log \mathrm{a}\left(\mathrm{Mg}^{2+} /\left(\mathrm{H}^{+}\right)^{2}\right)$

$+\log a(c l i n o c h l o r e)$

$\log K$ for this reaction is -37.05 at $200^{\circ} \mathrm{C}$ and -33.22 at $250^{\circ} \mathrm{C}$. Assume that the activity of muscovite in a muscovite-paragonitepyrophyllite solid solution is calculated as the mole fraction of $\mathrm{K}^{+}$. If pure muscovite and albite are at equilibrium with a fluid at $250^{\circ} \mathrm{C}$, then a reduction in temperature of $50^{\circ}$, while the activities of aqueous species and albite remain constant, will reduce the activity of muscovite by $0.51 \mathrm{log}$ units from an activity of 1 to 0.31 . If the temperature remains constant at $250^{\circ} \mathrm{C}$, then the same reduction in muscovite activity can be brought about by an increase in 109 $\mathrm{a}\left(\mathrm{Na}^{+} / \mathrm{H}^{+}\right)$of 0.17 , or a decrease in $\mathrm{pH}$ of 0.25 or of $\log \mathrm{a}\left(\mathrm{K}^{+} / \mathrm{H}^{+}\right)$of 0.51 . In a clinochlore-daphnite solid solution, 
$(\mathrm{Mg}, \mathrm{Fe})_{5} \mathrm{AI}\left[\mathrm{AlSi}_{3} \mathrm{O}_{10}\right](\mathrm{OH})_{8}$, the activity of clinochlore may be approximated by the mole fraction of $\mathrm{Mg}$ in the octahedral site raised to the sixth power, if an ideal ionic site mixing model is used and all octahedral sites are assumed to be energetically equivalent. A drop of $50^{\circ} \mathrm{C}$ while aqueous species activities remain constant will reduce $\log$ clinochlore activity to -3.83 . A mole fraction of $0.23 \mathrm{Mg}$ in octahedral sites equates to a $\log$ a(clinochlore) of -3.83 . If temperature is held constant, the same decrease in clinochlore activity can be effected by an increase in $\log$ a $\left(\mathrm{Na}^{+} / \mathrm{H}^{+}\right)$of 1.92 , an increase in $\mathrm{pH}$ of 0.48 units, or a decrease in $\log$ a $\left(\mathrm{Mg}^{2+} /\left(\mathrm{H}^{+}\right)^{2}\right)$ of 0.77 . Combinations of smaller variations in chemical parameters can cause the same changes in mineral end-member activities.

Although the above discussion concerns a simplified case of ideal ionic sericite and chlorite solid solutions, it does present some estimates of the sensitivity of mineral chemistry to fluid chemistry and temperature. Substitution of the cations in octahedral and tetrahedral sites will, of course, affect the stabilities of solid solutions, as will the substitution of fluorine for hydroxyl groups.

Additional complexity is evidenced by Page and Wenk (1979) and Geise (1974) who show that high strain energies resulting from crystal bonding and interlayering, and surface energies of finely crystalline phases will significantly modify the thermodynamic properties of alteration minerals, and may have as great an effect on the chemical potentials of crystalline phases as any amount of solid solution at least in the smectite-sericite series. These factors may be particularly important at Roosevelt Hot Springs where sericite is fine 
grained, and probably less so in the porphyry systems studied.

\section{Fluid Compositions}

The Roosevelt Hot Springs geothermal fluid is a dilute, near neutral $\mathrm{NaCl}$ brine with total dissolved solids near $7000 \mathrm{mg} / 1(0.7 \mathrm{wt}$ $\%$ ) and a measured $\mathrm{pH}$ at surface of 6.1 in fluid from Well 14-2. The temperature in the lower half of the well is uniform and near $250^{\circ} \mathrm{C}$ according to the most recent temperature $\log (11 / 15 / 76$-, Glenn, 1978). Waters from three welis, 72-16 (Parry et al., 1980), 14-2 and 54-3 (A. H. Truesdell, personal communication) have similar major element composition. A fluid analysis for Well 14-2 is presented in Table 3 .

Information on the compositions of fluids from porphyry copper deposits is available from fluid inclusion studies. A summary is provided by Roedder (1979) who states that fluid compositions vary in space and time, and usually have higher salinities and temperatures in central cores than in peripheral regions. Most ore fluids are $\mathrm{NaCl}$ brines and fall in the range $0-5 \mathrm{wt} \% \mathrm{NaCl}$ equivalent, al though up to $30 \mathrm{wt} \%$ and even $50 \mathrm{wt} \%$ and more is common in porphyry deposits. Geothermal fluids are often dilute, containing less than 1 wt\% total dissolved solids, with notable exceptions such as the Salton Sea and Reykjanes. Salton sea fluids in two wells contain 22 and 26 wt\% dissolved solids (Helgeson, 1969). It is worth noting that, despite extreme differences in salinity and concentration of dissolved species in geothermal fluids the compositions of sericite and chlorite from the Salton Sea and Roosevelt systems are quite similar. In particular 
Table 3. Water Analysis: Thermal Power Company Well 14-2. Roosevelt Hot Springs

$\begin{array}{rrrr} & & \begin{array}{c}\text { Assuming } \\ 10 / \text { st. loss }\end{array} & \begin{array}{l}\text { Assuming } \\ 20 / \text { st. loss }\end{array} \\ \mathrm{SiO}_{2} & 640 & 576 & 512 \\ \mathrm{Al}^{*} & .28 & .25 & .22 \\ \mathrm{Fe}^{\star} & .03 & .03 & .02 \\ \mathrm{Ca} & 8.0 & 7.2 & 6.4 \\ \mathrm{Mg} & .08 & .07 & .06 \\ \mathrm{Na} & 2180 & 1962 & 1744 \\ \mathrm{~K} & 400 & 360 & 320 \\ \mathrm{SO}_{4}= & 69 & 62 & 55 \\ \mathrm{Cl} & 3650 & 3285 & 2920 \\ \mathrm{~F} & 5 & 4.5 & 4 \\ \mathrm{pH}^{*} & 6.1 & & \end{array}$

Units: ppm.

All Analyses by A. H. Truesdell. As, Sr, Li, B analyses not included.

*Analyses for Phillips Well 54-3 (A. H. Truesdell, personal communication)

$\star \star \mathrm{pH}_{\text {(measured) }}$ 
the two wells reported by Helgeson (1969) contain 10 and $27 \mathrm{ppm} \mathrm{Mg,}$ and 2000 and $1200 \mathrm{ppm} \mathrm{Fe}$, compared with $0.08 \mathrm{ppm} \mathrm{Mg}$ and $0.03 \mathrm{ppm} \mathrm{Fe}$ reported for Roosevelt by A. H. Truesdell. Assumed here, of course, is that alteration minerals analyzed formed in response to the present fluids.

Mineral-Fluid Energy Relationships

Modeling of the energy relationships between the present day geothermal fluid and ideal end-member minerals has been performed to determine whether or not fluid and minerals are at or close to equilibrium.

Modeling of the aqueous species distribution in the Roosevelt geothermal fluid has been performed using a water analysis from Well 14-2. Al and $\mathrm{Fe}$ analyses, not available for Well 14-2, are those from Well 54-3 (Phillips Petroleum Company). Fluids from the two wells are similar in composition and the Al and Fe analyses from Well 54-3 are assumed to be reasonable estimates of the concentrations in Well 14-2. All water analyses have been kindly provided by A. H. Truesdell. The distribution of aqueous species has been computed using two different computer programs. Each has a different data base and each uses a different method to calculate equilibrium constants at elevated temperatures. WATEQF (Plummer et al., 1976) utilizes the Van't Hoff equation and assumes reaction enthalpy to be independent of temperature. A version of PATH (Helgeson, 1969; modified by D. Norton and G. Knight) computes the temperature dependence of enthalpy using average heat capacities for ions. An additional difference is that 
WATEQF includes fluoride complexes of major ions while PATH does not. Both programs use extended Debye-Huckel theory to estimate activity coefficients for aqueous species, and both require $\mathrm{pH}$ and temperature as input variables. The results of the two programs are similar, except for calculated activity of $\mathrm{Al}^{3+}$, as discussed later. Species distribution by WATEQF for the major ions is presented in Table 4. An Eh of zero is assumed to distribute $\mathrm{Fe}$ species. Input values chosen for $\mathrm{pH}$ are 5.5 and 6.0 . The measured $\mathrm{pH}$ at surface of fluid from Well $14-2$ is 6.1 , after steam loss. It is assumed that $\mathrm{pH}$ at depth is close to neutral. Neutral pH is 5.64 and 5.60 at 200 and $250^{\circ} \mathrm{C}$ respectively at vapor saturation and 5.58 and 5.51 at 250 bars (Marshal1, 1977). A pH of 6.3 has been calculated from K-feldspar-muscovite-quartz equilibria using data from Helgeson (1969) (D. Rohrs, personal communication.) 5.5 and 6.0 were chosen as reasonable values. Calculations were made assuming $10 \%$ and $20 \%$ steam loss from the fluid prior to analysis. $10 \%$ and $20 \%$ were chosen from calculations of fluid and steam enthalpy differences between the sample collection temperature of $190^{\circ} \mathrm{C}$ and the reservoir temperature. $14 \%$ steam loss is calculated for a reservoir temperature of $272^{\circ} \mathrm{C}$, the silica geothermometer temperature.

The $\log$ activity values for the major species, (Table 4) show that neither $\mathrm{pH}$ nor temperature has a large effect on activities of most species. Of the species considered in the hydrolysis reactions only $\mathrm{Al}^{3+}$ activity changes by more than a log unit. $\mathrm{Fe}^{2+}, \mathrm{Fe}^{3+}$ and $\mathrm{Ca}^{2+}$ change by several tenths of a $\log$ unit, but other species remain almost constant. $\mathrm{Al}(\mathrm{OH})_{4}$ remains constant al though both $\mathrm{Al}^{3+}$ and 
Table 4. Calculated* activities of aqueous species in Well 14-2 fluid assuming 10\% and $20 \%$ steam loss.

$10 \%$ Steam Loss

$20 \%$ Steam Loss

Temp ${ }^{\circ} \mathrm{C}$

$\mathrm{pH}^{+}$

$\mathrm{Ka}^{+}{ }^{+}$

$\mathrm{Mg}^{2+}$

$\mathrm{MgF}^{+}$

$\mathrm{Fe}^{2+}$

$\mathrm{Fe}^{3+}$

$\mathrm{Al}^{3+}$

$\mathrm{Al}(\mathrm{OH})_{4}^{-}$

$\mathrm{AlF}_{2}^{+}$

$\mathrm{H}_{4} \mathrm{SiO}_{4}(\mathrm{aq})$

$\mathrm{Cl}^{-}$

$\mathrm{SO}_{4}=$

$\mathrm{F}^{\prime}$
250

$$
5.5
$$

$-1.27$

$-2.00$

$-4.34$

$-6.18$

$-6.68$

$-7.12$

$-17.08$

$-19.02$

$-5.19$

$-7.55$

$-2.01$

$-1.19$

-4.01
-3.79

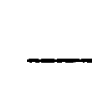

\section{0}

$$
-1.22
$$

$-2.20$

$$
-4.34
$$

$-6.21$

$-6.71$

$-7.48$

$-17.44$

$-21.02$

$-5.19$

$-9.55$

$-2.01$

$-1.20$

$-3.96$

$-3.79$
200

$\begin{array}{cc}5.5 & 6.0 \\ -1.19 & -1.19\end{array}$

$-2.16$

$-4.21$

$-6.03$

$-6.70$

$-6.83$

$-17.21$

$-17.06$

$-5.18$

$-6.40$

$-2.01$

$-1.16$

$-3.84$

$-2.76$
$-2.16$

$-4.22$

$-6.04$

$-6.71$

$-6.70$

$-17.38$

$-19.04$

$-5.15$

$-8.37$

$-2.01$

$-1.16$

\begin{tabular}{|c|c|c|c|}
\hline \multicolumn{4}{|c|}{$20 \%$ Steam Loss } \\
\hline & 250 & & \\
\hline $\begin{array}{c}5.5 \\
-1.27 \\
-2.24 \\
-4.37 \\
-6.22 \\
-6.76 \\
-7.28 \\
-17.24 \\
-19.07 \\
-5.24 \\
-7.68 \\
-2.06 \\
-1.24 \\
-4.03 \\
-3.84\end{array}$ & $\begin{array}{r}6.0 \\
-1.27 \\
-2.24 \\
-4.37 \\
-6.25 \\
-6.76 \\
-7.65 \\
-17.61 \\
-21.07 \\
-5.24 \\
-9.68 \\
-2.06 \\
-1.24 \\
-3.98 \\
-3.84\end{array}$ & $\begin{array}{c}5.5 \\
-1.23 \\
-2.21 \\
-4.24 \\
-6.08 \\
-6.79 \\
-6.99 \\
-17.37 \\
-17.11 \\
-5.22 \\
-6.54 \\
-2.06 \\
-1.20 \\
-3.86 \\
-3.80\end{array}$ & $\begin{array}{c}6.0 \\
-1.23 \\
-2.21 \\
-4.25 \\
-6.09 \\
-6.80 \\
-7.16 \\
-17.55 \\
-19.09 \\
-5.20 \\
-8.52 \\
-2.06 \\
-1.20 \\
-3.85 \\
-3.80\end{array}$ \\
\hline
\end{tabular}

$-3.83$

$-3.75$

*Calculated using WATEQF (Plumer et al, 1976). Values are log (activity) 
$\mathrm{AlF}_{2}{ }^{+}$change by several log units.

Robie et al. (1978) and Helgeson et al. (1978) have been used as sources of thermodynamic data for solid phases. Sericite and chlorite have been treated as solid solutions of end-members. Both compilations include measured data for muscovite only, and estimation methods have been used to provide enthalpies, entropies and heat capacity power functions for other end-members (Appendix V).

Thermodynamic parameters needed for each of the end-members are enthalpy and entropy at $298.15^{\circ} \mathrm{C}$, and the heat capacity power function, which is used to calculate the additional contribution of each of the former to the Gibbs free energy at higher temperatures. The simplest and most precise method of calculating these three parameters for an unknown mineral is to hypothetically produce that mineral by reaction of other minerals for which thermodynamic data is available. Enthalpies, entropies and Gibbs free energies are obtained by summation, and heat capacity power functions are obtained by summation of the coefficients of the appropriate temperature terms.

The estimation method of obtaining thermodynamic data for sericite and chlorite end-members was used 1) because the method provides reasonable approximations from a consistent data set, and 2) because of the problems of obtaining reliable measurements.

Two different alteration assemblages are present in the samples analyzed from well 14-2 at Roosevelt: an upper sericite-hematite assemblage, and a lower chlorite-calcite-pyrite-sericite assemblage in which sericite abundance is often small compared to chlorite. Both assemblages cannot be simultaneously in equilibrium with the present 
day bulk geothermal fluid flowing at the well head. Both could, however, be formed from the same parent fluid which has changed composition, for example by cooling and/or changing $\mathrm{pH}$ or oxidation potential as it flowed or percolated toward the surface. Alteration minerals may well be of more than one generation.

The problem of determining whether or not alteration minerals are in equilibrium with the present day geothermal fluid can be approached in three ways, only the second of which will be discussed in detail. The first involves calculating stability fields of minerals present in the system using activity-activity diagrams, and comparing the present day fluid composition with the stability fields of minerals on the diagram. This approach requires that some component involved in mineral-mineral reactions be conserved. Aluminum is the component usually conserved and is probably the best approximation, but reactions can also be written conserving volume or silica or some other component, and stability field boundaries shift accordingly. The second approach involves comparing values of the reaction quotient expression for the hydrolysis of an end-member mineral under two conditions: 1) at equilibrium where the reaction quotient has the theoretical value of the equilibrium constant $(K)$, and 2 ) when the reaction quotient has the value of the ion activity product (IAP) of aqueous species in the bulk geothermal fluid. The third approach involves calculating reduced activities of end-members in sericite and chlorite solid solutions, using actual analytical data from coexisting sericite-chlorite pairs, and solving a set of simultaneous hydrolysis reaction equations for the activities of aqueous species in assumed 
equilibrium with the solid phases. This third approach requires assumptions and estimations, which are not quite valid or accurate and to date has not been successful. It will not be discussed further in this report.

The second method may be simply represented by the equation:

$$
\Delta G_{r}=2.303 R T \log (I A P / K)
$$

where $\Delta G_{r}$ is the Gibbs free energy of the reaction, $R$ the gas constant, $T$ temperature in degrees Kelvin, and $K$ and IAP the equilibrium constant and ion activity product respectively for the hydrolysis reaction. Log $K$ values for hydrolysis reactions of major minerals present in the system have been calculated using the two sets of data discussed earlier. Log IAP values (Table 5) for the geothermal fluid from well 14-2 were calculated using WATEQF (Plumer et al., 1976). Theoretically, minerals and fluid are at equilibrium when $\Delta G_{r}$ is zero, $i$.e when $I A P=K$, and positive and negative values for $\Delta G_{r}$ indicate respectively supersaturation and undersaturation of the fluid with a pure mineral (Barnes et al., 1978). Figure 21 shows the values of $\log (I A P / K)$ for sericite, chlorite and feldspar end-members .

The value-(IAP/K) may also be considered as the activity that a mineral phase in solid solution must have in order to be in equilibrium with the fluid. For example, if $\log (I A P / K)$ for muscovite has the value -0.5 then the $\log$ activity of muscovite in a mica solid solution in equilibrium with the fluid will be +0.5. Any other value for muscovite activity would indicate lack of equilibrium between bulk 
Table 5. Hydrolysis Reaction Equilibrium Constants ( $K$ ) and Ion Activity Products (IAP) for Well 14-2 Geothermal Fluid.

$\%$ Steam Loss

$\mathrm{pH}$

Temperature $\left({ }^{\circ} \mathrm{C}\right)$

Clinochlore $\quad\left(\mathrm{Al}^{3+}\right)^{2}\left(\mathrm{H}_{4} \mathrm{SiO}_{4}\right)^{3}\left(\mathrm{H}_{2} \mathrm{O}\right)^{6}\left(\mathrm{Mg}^{2+}\right)^{5}\left(\mathrm{H}^{+}\right)^{-16}$

Daphnite $\quad\left(\mathrm{Al}^{3+}\right)^{2}\left(\mathrm{H}_{4} \mathrm{SiO}_{4}\right)^{3}\left(\mathrm{H}_{2} \mathrm{O}\right)^{6}\left(\mathrm{Fe}^{2+}\right)^{5}\left(\mathrm{H}^{+}\right)^{-16}$

Muscovite $\quad\left(\mathrm{Al}^{3+}\right)^{3}\left(\mathrm{H}_{4} \mathrm{SiO}_{4}\right)^{3}\left(\mathrm{H}^{+}\right)^{-10}\left(\mathrm{~K}^{+}\right)$

Celadonite $\quad\left(\mathrm{Al}^{3+}\right)\left(\mathrm{H}_{4} \mathrm{SiO}_{4}\right)^{4}\left(\mathrm{H}^{+}\right)^{-6}\left(\mathrm{H}_{2} \mathrm{O}\right)^{-4}\left(\mathrm{Mg}^{2+}\right)\left(\mathrm{K}^{+}\right)$

Illite

$\left(\mathrm{Al}^{3+}\right)^{2.25}\left(\mathrm{H}_{4} \mathrm{SiO}_{4}\right)^{3.5}\left(\mathrm{H}^{+}\right)^{-8}\left(\mathrm{H}_{2} \mathrm{O}^{-2}\right)\left(\mathrm{Mg}^{2+}\right)^{0.25}\left(\mathrm{~K}^{+}\right)^{.75}$

Ferrimuscovite $\left(\mathrm{Al}^{3+}\right)\left(\mathrm{H}_{4} \mathrm{SiO}_{4}\right)^{3}\left(\mathrm{H}^{+}\right)^{-10}\left(\mathrm{Fe}^{3+}\right)^{2}\left(\mathrm{~K}^{+}\right)$

Pyrophyllite $\quad\left(\mathrm{Al}^{3+}\right)^{2}\left(\mathrm{H}_{4} \mathrm{SiO}_{4}\right)^{4}\left(\mathrm{H}^{+}\right)^{-6}\left(\mathrm{H}_{2} \mathrm{O}\right)^{4}$

Paragonite $\quad\left(\mathrm{Al}^{3+}\right)^{3}\left(\mathrm{H}_{4} \mathrm{SiO}_{4}\right)^{3}\left(\mathrm{H}^{+}\right)^{-10}\left(\mathrm{Na}^{+}\right)$

Aibite $\quad\left(\mathrm{Al}^{3+}\right)\left(\mathrm{H}_{4} \mathrm{SiO}_{4}\right)^{3}\left(\mathrm{H}^{+}\right)^{-4}\left(\mathrm{H}_{2} \mathrm{O}\right)^{-4}\left(\mathrm{Na}^{+}\right)$

Anorthite $\quad\left(\mathrm{Al}^{3+}\right)^{2}\left(\mathrm{H}_{4} \mathrm{SiO}_{4}\right)^{2}\left(\mathrm{H}^{+}\right)^{-8}\left(\mathrm{Ca}^{2+}\right)$

Microcline $\quad\left(\mathrm{Al}^{3+}\right)\left(\mathrm{H}_{4} \mathrm{SiO}_{4}\right)^{3}\left(\mathrm{H}^{+}\right)^{-4}\left(\mathrm{H}_{2} \mathrm{O}^{-4}\left(\mathrm{~K}^{+}\right)\right.$ $\log K^{*}$

$\log K \star \star \quad \log I A P \star \star \star$

$\begin{array}{lllll}10 & 10 & 10 & 10 & 20 \\ 5.5 & 6.0 & 5.5 & 6.0 & 5.5\end{array}$

$\begin{array}{lllllllll}200 & 250 & 200 & 250 & 250 & 250 & 200 & 200 & 250\end{array}$

$\begin{array}{lllllllll}30.1 & 24.3 & 31.3 & 26.8 & 13.0 & 16.9 & 17.7 & 21.7 & 12.6\end{array}$

$\begin{array}{lllllllll}110 . & 95.8 & 26.1 & 21.5 & 8.3 & 10.5 & 13.7 & 18.4 & 7.3\end{array}$

$\begin{array}{lllllllll}-0.22 & -2.4 & -2.0 & -3.4 & -10.1 & -11.3 & -4.4 & -5.3 & -10.6\end{array}$

$\begin{array}{lllllllll}0.1 & -0.4 & -0.1 & -0.4 & -2.2 & -1.5 & -.3 & .7 & -2.8\end{array}$

$\begin{array}{lllllllll}-20.4 & -20.8 & -41.7 & -43.5 & -8.9 & -9.5 & -4.5 & -5.0 & -9.4\end{array}$

$\begin{array}{lllllllll}-17.5 & -18.6 & -9.0 & -5.4 & -6.2 & -4.1 & -5.1 & -2.0 & -7.0\end{array}$

$\begin{array}{lllllllll}-5.9 & -7.0 & -10.7 & -11.1 & -13.1 & -14.1 & -9.2 & -10.1 & -13.4\end{array}$

$\begin{array}{lllllll}3.0 & .51 & -9.3 & -10.3 & -3.4 & -4.3 & -9.7\end{array}$

$\begin{array}{lllllllll}-0.9 & -1.5 & -0.1 & 0.4 & -4.3 & -4.3 & -2.3 & -2.3 & -4.5\end{array}$

$\begin{array}{lllllllll}8.1 & 5.1 & 5.4 & 3.2 & -2.4 & -2.4 & 1.7 & 1.7 & -2.6\end{array}$

$\begin{array}{lllllllll}-2.2 & -2.6 & 7.9 & 2.9 & -5.1 & -5.3 & -3.3 & -3.2 & -5.5\end{array}$

* Log $K$ calculated using data extracted and estimated from Helgeson et al, (1978) SUPCRT data file, and Helgeson (1969).

* Log K calculated using data extracted and estimated from Robie et al, (1978) and Helgeson (1969).

$\star \star *$ Aqueous species distribuiton calculated by WATEQF (PI ummer et al., 1976). 


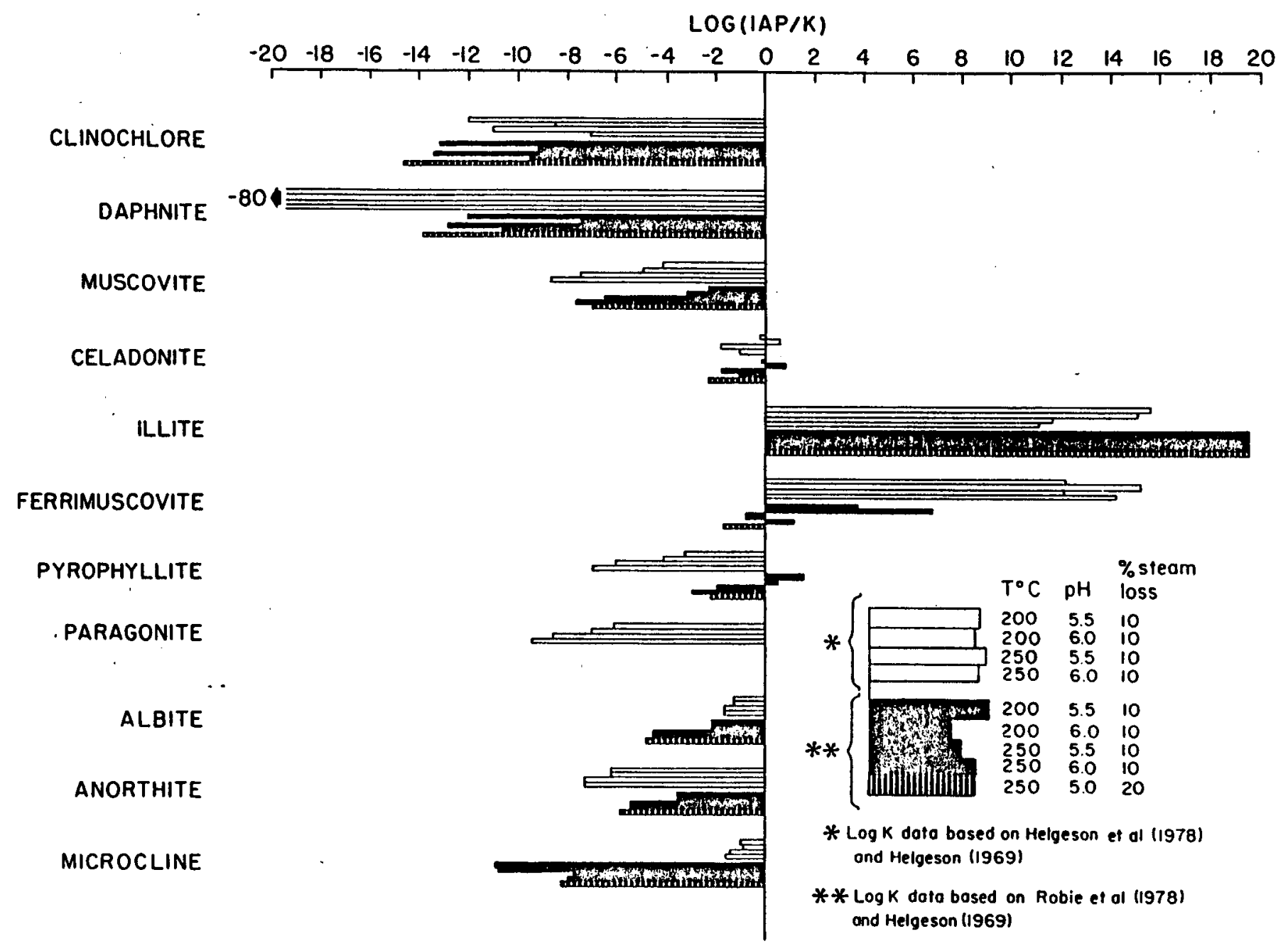

Figure 21. Fluid-mineral energy relationship: departure from equilibrium. Negative, zcro and positive values of $\log (\mathrm{IAP} / \mathrm{K})$ indicate undersaturation, equilibrium and supersaturation respectively of Well 14-2 fluid with mineral phases. 
fluid and mineral, providing the assumptions are valid. Herein lies the problem. Assumptions and their effects are discussed below.

Assumptions are 1) that the thermodynamic data are accurate and consistent, 2) that fluid analyses are sufficiently complete and accurate, 3) that temperatures are accurate, 4) that minerals are in contact with the bulk geothermal fluid and 5) that reactions taking place are indeed hydrolysis reactions occurring as written.

Figure 21 shows the effect of using two different sets of thermodynamic data to calculate $\log K$. Differences in $\log (I A P / K)$ are on the order of one or two units for clinochlore, muscovite and albite at $200^{\circ} \mathrm{C}$, less than a unit for celadonite, 5 or 10 units for most other minerals and several tens of units for daphnite and illite. Calculation of the magnitude of errors in $\log \mathrm{K}$ introduced by errors in thermodynamic data can be calculated from the equation:

$$
\Delta G^{\circ}=-2.303 \text { RT } \log K
$$

where $\Delta G^{\circ}$ is the standard free energy of reaction at equilibrium and other parameters are as previously defined. For a mineral having a free energy of formation of $-6,000$ kilojoules at $298.15^{\circ} \mathrm{K}$ a decrease in free energy (to more negative values) of 1,10 and 100 kilojoules will decrease the value of $\log K$ by $.17,1.75$ and 17.51 units respectively. Thus the effect of uncertainties in mineral thermodynamic data is probably the largest source of error. Errors are also introduced by the fact that WATEQF, the program used to calculate ion activities for log IAP uses thermodynamic data which may not be consistent with Helgeson (1969), Helgeson et al., (1978) and 
Robie et al., (1978). Distribution of aqueous species has also been calculated using PATH (Helgeson, 1970). Data are not shown here because tables and figures had been prepared prior to running PATH.

Log activities of major species calculated by PATH and WATEQF at $250^{\circ} \mathrm{C}$ and $\mathrm{a} \mathrm{pH}$ of 5.5 differ by less than $0.2 \mathrm{log}$ units except for $\mathrm{Al}^{3+}$ and $\mathrm{Fe}^{2+}$ (calculated as total $\mathrm{Fe}$ ) which are -16.78 and -8.30 respectively for PATH and -19.02 and -7.12 for WATEQF. Values of $10 \mathrm{~g}$ (IAP/K) if PATH is used to distribute aqueous species are 6 to 7 units more positive in the case of muscovite and paragonite, 4 to 5 units more positive in the case of clinochlore, illite, pyrophyllite and anorthite, approximately 2 units more positive in the case of albite, microcline and celadonite, and 1.4 more negative for daphnite. The effect is to bring all end members except daphnite, illite and pyrophyllite closer to equilibrium with the fluid.

PATH and WATEQF have different thermodynamic data bases and use different methods for prediction of $\log K$ values for aqueous species' equilibria at elevated temperatures. WATEQF uses the Van't Hoff equation assuming constant enthalpy, while PATH uses analytic expressions involving heat capacity power functions to calculate enthalpies at elevated temperatures. Errors are also introduced in the aqueous species distribution calculations by inaccuracies in equilibrium constants for aqueous species reactions. The magnitude of these errors has not been determined but is expected to cause errors in $\log$ IAP of not more than one or two units.

The assumption that fluid analyses are sufficiently complete and accurate is a good approximation. $A 1$ and $\mathrm{Fe}$ analyses are from well 
54-3, not 14-2, but the two fluids are similar in composition (A. H. Truesdell, personal communication). A $10 \%$ error in analytical accuracy can be represented by the difference between $10 \%$ and $20 \%$ steam. loss. Table 4 and Figure 21 show the effect is very small. Errors in calculation of $\mathrm{pH}$ introduce the largest errors.

The assumption that observed hydrothermal minerals are in equilibrium with the bulk geothermal fluid may not be accurate. The bulk geothermal fluid is that flowing through major fractures and channelways. Fluid moving away from these through small fractures and percolating into the rock changes in composition by reaction with rock minerals and by differences in diffusion rates of various ions. Alteration minerals are likely to be in equilibrium with local portions of fluid which have changed composition since moving out into the rock away from major fractures. Some alteration may also predate the present geothermal activity.

Reactions actually taking place may not be those written, and some intermediate product may be controlling equilibrium. Possible effects of this, or of kinetic processes have not been evaluated.

All of the above assumptions and uncertainties can effect the value of $\log (I A P / K)$ by several units, and perhaps more. However, within these limits, figure 21 has some interesting implications. Consider the data set based on thermodynamic data for Robie et al. (1978), represented by black bars. These are calculated at 200 and $250^{\circ} \mathrm{C}$, and at $\mathrm{pH}^{\prime} \mathrm{s}$ of 5.5 and 6.0 with an assumed $10 \%$ steam loss during sample collection. Celadonite, ferrimuscovite and pyrophyllite are all near equilibrium somewhere between 200 and $250^{\circ} \mathrm{C}$ in this $\mathrm{pH}$ 
range. If PATH is used for species distribution muscovite is also close to equilibrium. Illite is strongly supersaturated, and the feldspars and chlorites are all undersaturated. Calculations using calcite, $\mathrm{CO}_{2}$, water equilibria, and thermodynamic data from Helgeson (1969) at $250^{\circ} \mathrm{C}$ and $\mathrm{pH} 5.5$ provide a $\mathrm{pCO}_{2}$ of $10-1.19$, a reasonable value, within the range used by Parry et al (1980). Calcite is probably stable in association with the geothermal fiuid. Two important factors are 1) that an Al analysis is not available for well 14-2, although the data from Phillips well 54-3 is probably similar, and 2) that $\mathrm{pH}$ is estimated, not measured. The two parameters having the largest effect on changes of $\log$ IAP are the activities of $\mathrm{Al}^{3+}$ and $\mathrm{pH} . \log \mathrm{a}\left(\mathrm{Al}^{3+}\right)$ is markedly sensitive to both $\mathrm{pH}$ and temperature, whereas the activities of $\mathrm{K}^{+}, \mathrm{Na}^{+}$, and $\mathrm{H}_{4} \mathrm{SiO}_{4}$ are relatively insensitive. Errors in chlorite thermodynamic data are likely to have caused the magnitude of calculated chlorite undersaturation to be too large.

The implication of the thermodynamic calculations is that the analyzed bulk geothermal fluid is either not in equilibrium with the chlorite-sericite-calcite-pyrite assemblage in the lower part of the well or not in equilibrium with the chlorite in that assemblage. The intensely altered zone between 850 and $880 \mathrm{~m}$ is thought to be the main hot water entry zone (Bamford, 1978, Bamford et al., 1980, Glenn and Hulen, 1979) because the well is cased to $551 \mathrm{~m}$. However, alteration mineralogy in this zone is not identical in all chips from one sample. Plagioclase is altered to chlorite, sericite and calcite, together or singly. It is possible that chlorite was formed during an earlier 
hydrothermal event. Textural evidence neither confirms nor denies this possibility. Well $14-2$ is interpreted to parallel one or more nearly isothermal fractures, (Glenn and Hulen, 1979). Some of the sericite observed between 850 and $880 \mathrm{~m}$ may have been formed in response to the same fluids which caused sericitic alteration higher in the well. 
SUMMARY AND CONCLUSIONS

Compositional variation in sericites and chlorites from hydrothermal systems is a function not only of bulk fluid chemistry and temperature, but also of the chemical environment in the immediate vicinity of the alteration minerals. Distance from fluid-bearing veins and the nature of the mineral being replaced, are important factors in rocks which are not totally recrystallized by hydrothermal processes. In pervasively altered rocks from porphyry copper systems chemical equilibrium between coexisting sericite and chlorite, and presumably also between minerals and fluid, appears to be often attained. However, in the Roosevelt Hot Springs geothermal system, chemical imhomogeneity of alteration minerals, isotopic evidence and thermodynamic modeling all indicate a state of disequilibrium between the bulk geothermal fluid and hydrothermal sericite and chlorite al though local portions of the fluid modified by reaction with rock may be in equilibrium. Sericite chemistry is a function of alteration assemblage, and also appears to exhibit different patterns in different hydrothermal systems. The latter may be partly due to the distribution of sampled alteration assemblages in the different systems. Chlorites from propylitic alteration assemblages in four systems have similar ranges in octahedral substitution. Chlorites from a sericite-pyrite- colorless chlorite porphyry copper assemblage; however, have exceptionally high Mg contents.

The compositional variation of sericites and chlorites from well 
14-2 at the Roosevelt Hot Springs geothermal system is as large within individual cuttings samples as between samples from different depths. Two known hot water entries have sericite compositional ranges which are not distinctly different from other depths. The observed variation can be explained as a function of disequilibrium between rock and present day bulk fluid. In other hydrothermal syștems sericite chemistry is observed to vary with distance from a vein (Page and Wenk, 1979) and between vein and rock matrix (this report). A sample from a geothermal well is composed of cuttings, (representing at least a five or ten foot interval and probably considerably more) in which chips from different distances from veins and also perhaps from different stages of hydrothermal alteration are jumbled together. Alteration intensity in Well 14-2 is high near hot water entry zones, but mineral chemistry, at least on the scale sampled, is not diagnostic of such zones. Glenn (1979.) suggests that Well 14-2 may have been drilled parallel and close to a fluid-bearing fracture. If so, hot water entries may be intersections with this fracture, but alteration chemistry would not exhibit major downhole differences.

Thermodynamic modeling of the sensitivity of mineral chemistry to fluid chemistry indicates that relatively small changes in $\mathrm{pH}$ and aqueous species activities can cause major changes in the activities of solid solution end-members, and hence of alteration mineral compositions. Modeling shows the geothermal fluid is close to equilibrium with calcite, and the end-members of sericite solid solutions, but is undersaturated with respect to chlorite. The suggestion from this data is that chlorite in the lower portion of the 
well formed earlier than at least part of the sericite. Modeling of a hypothetical fluid in equilibrium with analyzed sericite-chlorite pairs has been attempted but proved unsuccessful because of non-ideality of solid solutions, inaccuracies in estimated thermodynamic data and possible non-equilibrium between sericite and chlorite.

Results of research indicate that sericite and chlorite chemistry in the Roosevelt Hot Springs geothermal system is highly variable, and that mineral chemistry, at least on the scale sampled, does not distinguish hot water entry zones. Sericite and chlorite chemistry may prove useful in pervasively recrystallized hydrothermal systems, or in systems where vein fillings can be easily identified and analyzed (difficult in cuttings samples). Any future work should focus on coexisting sericite-chlorite pairs, or other coexisting phases, to minimize the number of degrees of freedom in the mineral system studied. 


\section{ACKNOWLEDGEMENTS}

Special thanks are due to William T. Parry, my research advisor, for his continued support and encouragement, and to Stanley $H$. Ward who obtained funding.

I am grateful to G. H. Ballantyne, R. W. Bamford, I. Barnes, J. Bowman, R. A. Capuano, D. Cole, G. K. Czamanske, S. H. Evans, R. 0. Fournier, H. C. Helgeson, L. Hitchner, R. W. Potter, R. Rogers, D. Rohrs, K. Roxlo, A. C. Tripp, and A. H. Truesdell for stimulating discussions and/or assistance at various stages of this research.

David C. Jacobs and Geoff H. Ballantyne provided analytical data from Santa Rita and Silver Bell respectively. Russell C. Babcock of Bear Creek Mining Company gave permission to collect data from Southwest Tintic.

Alfred H. Truesdell provided water analyses from Wells 14-2 and 54-3 at Roosevelt Hot Springs. Geoff H. Ballantyne wrote the Bence-Albee correction and structural formula calculation program. William T. Parry and John R. Bowman reviewed this manuscript, and earlier versions were reviewed by Lorie S. Cahn, Gerald K. Czamanske ànd Katherine R. Roxlo.

The research was supported by DOE/DGE Contract No. DE-AC07-78ET28392. 
Albee, A. L., 1962, Relationships between the mineral association, chemical composition and physical properties of the chlorite series. Am. Min., v. 47, p. 851-870.

Albee, A. L. and Ray, L., 1970, Correction factors for electron probe microanalysis of silicates, oxides, carbonates, phosphates and sulfates. Anal. Chem., v. 42, p. 1408-1414.

Alietti, A., Brigatti, M. F.; and Poppi, L., 1978, An illite/montmorillonite interlayer mineral in porphyritic rock of 'Alpe di Siusi' (BZ-Italy): The chemistry of I/M interlayer minerals. Clay minerals, v. 14, p. 39.

Ashley, P. M., 1980, Geology of the Ban Ban zinc deposit, a sulfidebearing skarn, Southeast Queensland, Australia. Econ. Geol. V. 75 p. 15-29.

Ashley, P. M., Billington, W. G., Graham, R. L., and Neale, R.C., 1978, Geology of the Coalstoun porphyry copper prospect, Southeast Queensland, Australia. Econ. Geol., v. 73, 945-965.

Ballantyne, J. M. and Parry, W. T., 1978a, Hydrothermal alteration at the Roosevelt Hot.Springs thermal area, Utah: petrographic characterization of the alteration to 2 kitometers depth. Technical report 78-1701-a.1.1 DOE/DGE contract EG-78-7-07-1701, 26 p.

Ball antyne, J. M. and Parry, W. T., 1978b, Hydrothermal alteration at the Roosevelt Hot Springs thermal area, Utah: modal mineralogy, and geochemistry of sericite, chlorite, and feldspar. from altered rocks, Thermal Power Company Well Utah State 14-2, Topical report 78-1701-a.1.1.5. DOE/DGE contract EG-78-C-07-1701, 42 p.

Bamford, R. W., Christensen, O. D., and Capuano, R. M., 1979, Multielement geochemistry of solid materials in geothermal systems and its applications - Part I: The hot water system at Roosevelt Hot Springs KGRA, Utah. Earth Science Laboratory/University of Utah Research Institute Report No. 30, DOE/DGE contract DE-ACO3-79ET27002, 168 p. (in press).

-Barnes, I.; Downes, C...J., and Hulston, J. R., 1978, Warm Springs, South Island, New Zealand, and their potentials to yield laumontite. Am. Jour. Sci. v. 278, p. 1212-1427.

Bence, A. E. and Albee, A. L., 1968, Empirical correction factors for the electron microanalysis of silicates and oxides. Jour. Geol., v. 76 , p. 382-406.

Blatter, C. L., Roberson, H. E., and Thompson, G. R., 1973, Regularly 
interstratified chlorite-dioctahedral smectite in dike-intruded shales, Montana. Clays Clay Miner., v. 21, p. 207-212.

Bloss, F. D., 1971, Crystallography and crystal chemistry. Holt, Rinehard and Winston, Inc., $545 \mathrm{p}$.

Brown, P. R. L. and Ellis, A. J., 1970, The Ohaki-Broadlands hydrothermal area, New Zealand: mineralogy and related geochemistry. Am. Jour. Sci., v. 269, p. 97-131.

Cheney, J. T. and Guidotti, C. V., 1973, Paragonite contents of coexisting, but texturally different, muscovites from pelitic schists of the Puzzle Mountain area, Maine. Am. Min., v. 58, p.1076-1079.

Chivas, A. R., 1978, Porphyry copper mineralization at the Koloula igneous complex, Guadalcanal, Solomon Islands. Econ. Geol., v. 73 , p. $645-677$.

Deer, W. A., Howie, R. A., and Zussman, J., 1966, An introduction to the rock-forming minerals. Longman, $528 \mathrm{p}$.

Dibble, W. E., 1978, The influence of fluorine on the thermodynamic stability of sheet silicates. Abstract, Transactions American Geophysical Union, v. 59, no. 12, p. 1218.

Downey, L. M., 1976, Geochemistry of hydrothermal chlorites, Gold Hill, Utah. M. S. thesis, University of Utah, 65 p.

Dunyoyer de Segonzac, G., 1970, The transformation of clay minerals during diagenesis and low grade metamorphism. Sedimentology, $v$. 15, p. 281-344.

Eaton, Frank M., McLean, G. W., Bredell, G. S., Doner, H. E., 1968, Significance of silica in the loss of magnesium from irrigation waters, Soil Science. v. 105, no. 4, p. 260-279.

Eberl, D. and Hower, J., 1977, The hydrothermal transformation of sodium and potassium smectite into mixed-layer clay. Clays Clay Miner., v. 25, p. 215-227.

Eslinger, E., Highsmith, P., Albers, D., and deMayo, B., 1979, Role of iron reduction in the conversion of smectite to illite in bentonites in the disturbed belt, Montana. Clays Clay Miner.; $v$. 27 , p. 327-328.

Eslinger, E. V. and Savin, S. M., 1973, Mineralogy and oxygen isotope geochemistry of the hydrothermally altered rocks of the Ohaki-Broadlands, New Zeal and Geothermal Area. Am. Jour. Sci., v. 273 , p. 260-267. 
Ford, J. H., 1978, A chemical study of alteration at the Panguna porphyry copper deposit, Bouganville, Papua New Guinea. Econ. Geol., v. 73, p. 703-720.

Giese, R. F. Jr., 1974, Surface energy calculations for muscovite. Nature v. 248, p. 580-588.

Glenn, W. E. and Hulen, J. B., 1979, Interpretation of well log data from 4 drillholes at Roosevelt Hot Springs KGRA. Earth Science Laboratory, University of Utah Research Institute Report 28, DOE/DGE contract EG-78-C-07-1701. 74 p.

Grandquist, W. T., Hoffman, G. W., and Boteler, R. C., 1972, Clay mineral synthesis-III, Rapid hydrothermal crystallization of an aluminian smectite. Clays Clay miner., v. 20, p. 323-329.

Guidotti, C. V., 1973, Compositional variation of muscovite as a function of metamorphic grade and assemblage in metapelites from N.W. Maine. Contrib. Mineral. Petrol., v. 42, p. 33-42.

Guidotti, C. V., 1978, Compositional variation of muscovite in medium- to high-grade metapelites in northwestern Maine. Am. Min., v. 63 , p. 878-884.

Guilbert, J. M. and Schafer, R. W., 1978, Preliminary Geochemical characterization of muscovites in porphyry base metal alteration assemblages. IAGOD Fifth Symposium, Programs and Abstracts, p. 92.

Guilbert, J. M. and Sloan, R. L., 1968, Electron-optical study of hydrothermal fringe alteration of plagioclase in quartz monzonite, Butte district, Montana. Clays Clay Miner., v. 16, p. 215-221.

Hel geson, H. C., 1968, Geologic and thermodynamic characteristics of the Salton Sea geothermal system. Am. Jour. Sci., v. 266, p. 129-166.

Hel geson, H. C., 1969, Thermodynamics of hydrothermal systems at elevated temperatures and pressures. Am.: Jour. Sci., v. 267, p. 729-804.

Hel geson, H. C., 1970, A chemical and thermodynamic model of ore deposition in hydrothermal systems. Mineral. Soc. Amer., spec. pap. 3 , p. 155-186.

Helgeson, H. C., Delaney, J. M., Nesbitt, H. W., and Bird, D. K., 1978, Summary and critique of the thermodynamic properties of rock-forming minerals. Am. Jour. Sci., v. 278-A, 229 p. 
Hey, M. H., 1954, A new review of the chlorites. Min. Mag., v. 30, p. 277 .

Holman, J. P., 1978, Experimental methods for engineers. McGrawHill, 493 p.

Jacobs, D. C., 1976, Geochemistry of biotite in the Santa Rita and Hannover-Fierro stocks, central mining district, Grant County, New Mexico. Ph.D. thesis, University of Utah, 212 p.

Jacobs, D. C. and Parry, W. T., 1979, Geochemistry of biotite in the Santa Rita porphyry copper deposit, New Mexico. Econ. Geol., v. 74 , p. $860-887$.

Kelly, W. L. and Rye, R. 0., 1979, Geologic, fluid inclusion, and stable isotope studies of the tin-tungsten deposits of Panasqueira, Portugal. Econ. Geol. v. 74, p. 1721-1822.

Lowell, J. D., and Guilbert, J. M., 1970, Lateral and vertical zoning in porphyry ore deposits. Econ. Geol., v. 65, p. 373-408.

Marshall, W. L., 1977, Revised evaluation of the ion product of water: Description from 0 to $1000^{\circ} \mathrm{C}$ and from 1 to 10,000 bars. Statement for Moscow Meeting (September 10-16, 1977) of the International Association for the Properties of steam; Working Group III.

McDowell, S. D., 1978, Layer silicate minerals in borehole Elmore No. 1, Salton Sea geothermal field, California, U.S.A. University of California, Riverside, Institute of Geophysics and Planetary Physics report no. UCR/IGPP-78/15.

McDowell, S. D. and McCurry, M., 1978, Mineralogical variations in borehole Elmore no. 1, Salton Sea geothermal area. Preliminary report, University of California, Riverside, Institute of Geophysics and Planetary Physics, report no. UCR/IGPP-78/11.

Meunier, A. and Velde, B., 1979, Weathering mineral facies in altered granites: the importance of local small-scale equilibria. Mineralogical Magazine, v. 43, p. 261-8.:

Muffler, L. P. and White, D. E., 1969, Active metamorphism of upper cenozoic sediments in the Salton Sea geothermal field and the Salton trough. Southeastern California, Geol. Soc. Am. Bull., v. 80 , p. 157-182.

Nash, J. T., 1973, Microprobe analyses of sericite, chlorite, and epidote from Jerome. Arizona, Jour. Research, U.S. Geol. Survey, v. 1 , no. 6 , p. 673-678.

Page, R. and Wenk, H. R., 1979, Phyllosilicate alteration of plagio- 
clase studied by transmission electron microscopy. Geology, v. 7, p. 393-397.

Pankratz, L. B., 1964, High temperature heat contents and entropies of muscovite and dehydrated muscovite. U.S. Bur. Mines Rept. Inv. $6371,6 \mathrm{p}$.

Parry, W. T., 1978, Hydrothermal alteration at the Roosevelt Hot Springs thermal area, Utah: Part I, Mineralogy of the clay fraction from cuttings. Thermal Power Co. Well Utah State 14-2, Part II, Chemical compositions of rocks, Thermal Power Co. Weli Utah State 14-2, Technical report 78-1701-a.1.1.2, DOE/DGE contract EG-78-C-07-1701.

Parry, W. T., Ballantyne, J. M., Bryant, N. L., and Dedolph, R. E., 1980 , Geochemistry of hydrothermal alteration at the Roosevelt Hot Springs thermal area, Utah. Geochim. et Cosmochim. Acta., v. 44 , p. 95-102.

Plummer, N. L., Jones, B. F. and Truesdell, A. H., 1976, WATEQF-A Fortran-IV version of WATEQ, a computer program for calculating chemical equilibrium of natural waters. U.S. Geological Survey Water Resour. Invest. 76-13.

Reynolds, R. C., Jr. and Hower, J., 1970, The nature of interlayering in mixed layer illite-montmorillonites. Clays Clay Miner., v. 18, p. 25-36.

Robie, R. A., Hemingway, B. S., and Fisher, J. R., 1978, Thermodynamic propertjes of minerals and related substances at $298.15 \mathrm{~K}$ and 1 bar (105 pascals) pressure and at higher temperatures. U.S. Geol. Surv., Bu11. 1452, 456 p.

Robie, R. A., Hemingway, B. S., and Wilson, W. H., 1976, The heat capacities of calorimetry conference copper and of muscovite $\mathrm{KAl}_{2}$ (AlSi3) $\mathrm{O}_{10} \mathrm{O}(\mathrm{OH})_{2}$, pyrophyllite $\mathrm{Al}_{2} \mathrm{Si}_{4} \mathrm{O}_{10}(\mathrm{OH})_{2}$ and illite $\mathrm{K}_{3}(\mathrm{Al} / \mathrm{Mg})\left(\mathrm{Si}_{14} \mathrm{Al} \mathrm{I}_{2}\right) \mathrm{O}_{40}(\mathrm{OH})_{8}$ between 15 and $375 \mathrm{~K}$ and the ir standard entropies at 298.15K. Jour. Research U.S. Geol. Survey, v. 4 , no. 6 , p. 631-644.

Roedder, E., 1979, Fluid inclusions as samples of ore fluids, in Barnes, H. L. (ed.), Geochemistry of hydrothermal ore deposits. John Wiley and Sons, 798 p.

Rose, A. W. and Burt, D. M., 1979, Hydrothermal alteration. In Barnes, H. L. (ed.), Geochemistry of hydrothermal ore deposits, John Wiley and Sons, $798 \mathrm{p}$.

Steiner, A., 1968, Clay minerals in hydrothermally altered rocks at Wairakei, New Zealand. Clays Clay Miner., v. 16, p. 193-213. 
Weaver, C. E., 1979, Geothermal alteration of clay minerals and shales. Diagenesis, Technical report ONWI-21, Georgia Institute of Technology, DOE/DGE contract EG-76-C-06-1830. $176 \mathrm{p}$. 
Appendix I. Sericite Analyses. Southwest Tintic.

SUT I

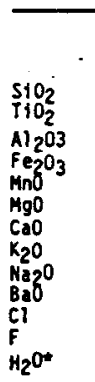

Total

52

S1

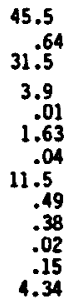

100.1

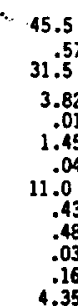

99.3

53

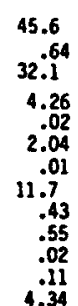

101.3

$\$ 7$

99.7

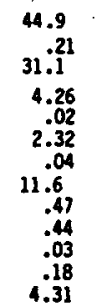

SuT 2

\begin{tabular}{ll}
\hline$s 1$ & $s 2$ \\
45.9 & 46.4 \\
.44 & .31 \\
34.5 & 34.9 \\
1.40 & 1.22 \\
.00 & .01 \\
3.07 & 2.31 \\
.03 & .07 \\
10.1 & 9.94 \\
.56 & .62 \\
.81 & .69 \\
.01 & .01 \\
. .35 &. .31 \\
4.32 & 4.35
\end{tabular}

101.3

\section{(1)}

$53 \quad 55$

$\begin{array}{ccc}46.3 & 47.2 & 45.5 \\ 34.27 & .33 & .33 \\ 34.4 & 34.4 & 33.4 \\ 1.24 & 1.44 & 1.33 \\ .00 & .00 & .00 \\ 3.22 & 1.69 & 4.00 \\ .04 & .06 & .14 \\ 10.1 & 9.91 & 9.91 \\ .56 & .56 & .55 \\ .99 & .90 & .82 \\ .01 & .01 & .01 \\ .31 & .27 & .42 \\ 4.34 & 4.37 & 4.28 \\ & & \end{array}$

Nunber of lons on the Basis of 22 Total Negattve Charges $10(0)$
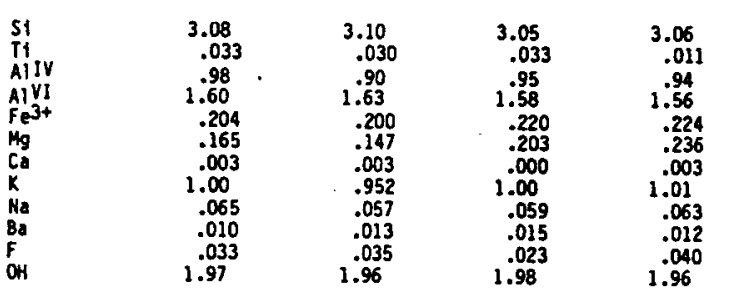

3.02
.022
.98
1.70
.069
.30
.002
.85
.072
.021
.072
1.93
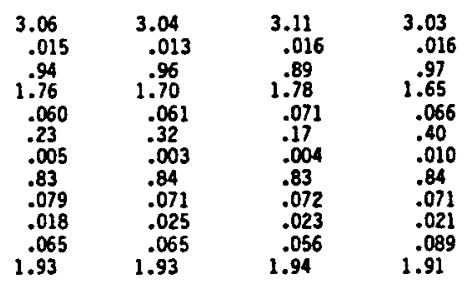

SHT 2

101.0

101.0

100.4

SLT 3

\begin{tabular}{|c|c|c|c|c|c|c|c|c|c|c|c|}
\hline & 58 & S9 & $\$ 10$ & 511 & $\$ 12$ & s2 & S2 & 56 & 510 & S15 & $\$ 14$ \\
\hline $\begin{array}{l}\mathrm{SiO}_{2} \\
\mathrm{TiO}_{2} \\
\mathrm{Al}_{2} \mathrm{O}_{3} \\
\mathrm{Fe}_{2} \mathrm{O}_{3} \\
\mathrm{MnO}^{2}\end{array}$ & $\begin{array}{c}46.5 \\
.29 \\
34.8 \\
1.10 \\
.01\end{array}$ & $\begin{array}{c}46.7 \\
34.42 \\
1.42 \\
.01\end{array}$ & $\begin{array}{c}47.2 \\
.34 \\
34.1 \\
1.39 \\
.01\end{array}$ & $\begin{array}{c}46.3 \\
.34 \\
32.9 \\
1.24 \\
.01\end{array}$ & $\begin{array}{c}45.9 \\
33.17 \\
1.13\end{array}$ & $\begin{array}{c}49.1 \\
.05 \\
35.5 \\
.49\end{array}$ & $\begin{array}{c}49.3 \\
.04 \\
35.2 \\
.62\end{array}$ & $\begin{array}{c}48.9 \\
.08 \\
35.4 \\
.37\end{array}$ & $\begin{array}{c}49.4 \\
.06 \\
35.0 \\
.77\end{array}$ & $\begin{array}{c}48.5 \\
.03 \\
35.5 \\
.45\end{array}$ & $\begin{array}{c}49.9 \\
.06 \\
35.3 \\
.54\end{array}$ \\
\hline $\begin{array}{l}\mathrm{MgO} \\
\mathrm{CaO} \\
\mathrm{K}_{2} \mathrm{O} \\
\mathrm{Na}_{2} \mathrm{O} \\
\mathrm{BaO}^{2} \\
\mathrm{Cl} \\
\mathrm{F} \\
\mathrm{H}_{2} \mathrm{O}^{\circ}\end{array}$ & $\begin{array}{r}3.97 \\
.36 \\
9.12 \\
.91 \\
1.14 \\
.01 \\
.47 \\
4.27\end{array}$ & $\begin{array}{r}2.87 \\
.10 \\
10.0 \\
.57 \\
.81 \\
.01 \\
.32 \\
4.34\end{array}$ & $\begin{array}{r}2.19 \\
.08 \\
10.0 \\
.57 \\
.74 \\
.00 \\
.32 \\
4.35\end{array}$ & $\begin{array}{r}2.72 \\
.17 \\
9.72 \\
.54 \\
1.04 \\
.01 \\
.38 \\
4.30\end{array}$ & $\begin{array}{r}3.92 \\
.08 \\
9.85 \\
.50 \\
1.00 \\
.01 \\
.47 \\
4.26\end{array}$ & $\begin{array}{r}1.46 \\
.00 \\
9.80 \\
.38\end{array}$ & $\begin{array}{r}1.60 \\
.00 \\
9.03 \\
.34\end{array}$ & $\begin{array}{r}1.49 \\
.00 \\
8.82 \\
.39 \\
\\
.14 \\
4.54\end{array}$ & $\begin{array}{r}2.02 \\
.00 \\
9.05 \\
.33 \\
\\
.21 \\
4.49\end{array}$ & $\begin{array}{r}1.69 \\
.00 \\
9.62 \\
.37 \\
\\
.18 \\
4.49\end{array}$ & $\begin{array}{r}1.48 \\
.00 \\
9.19 \\
.34 \\
\\
.16 \\
4.52\end{array}$ \\
\hline Total & 102.7 & 101.7 & 101.1 & 100.5 & 100.6 & 101.4 & 100.7 & 100.1 & 101.2 & 100.8 & 101.4 \\
\hline
\end{tabular}

Number of Ions on the Basis of 22 Total Hegative Charges 10(0) and $2(\mathrm{OH}, \mathrm{F}, \mathrm{C})$

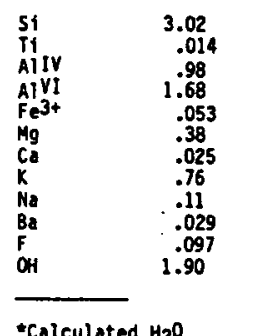

3.06
.021
.94
1.70
.070
.28
.007
.84
.072
.021
.067
1.93

$\begin{array}{cc}3.10 & 3.07 \\ .017 & .017 \\ .90 & .93 \\ 1.74 & 1.65 \\ .069 & .062 \\ .01 & .37 \\ .006 & .012 \\ .84 & .82 \\ .073 & .070 \\ .019 & .027 \\ .068 & .079 \\ 1.93 & 1.92\end{array}$

3.05
.008
.95
1.67
.056
.39
.006
.83
.064
.026
.099
1.90

$\begin{array}{ll}3.17 & 3.19 \\ .002 & .002 \\ .83 & .81 \\ 1.87 & .1 .87 \\ .024 & .030 \\ .14 & .15 \\ .000 & .000 \\ .81 & .75 \\ .048 & .043 \\ .038 & .018 \\ 1.96 & 1.98\end{array}$

$\begin{array}{llll}3.18 & 3.18 & 3.15 & 3.20 \\ .004 & .003 & .002 & .003 \\ .82 & .82 & .85 & .80 \\ 1.89 & 1.84 & 1.87 & 1.87 \\ .018 & .037 & .022 & .026 \\ .15 & .20 & .16 & .14 \\ .000 & .000 & .000 & .000 \\ .73 & .74 & .80 & .75 \\ .050 & .041 & .046 & .043 \\ .028 & .043 & .038 & .031 \\ 1.97 & 1.95 & 1.96 & 1.97\end{array}$

*Calculated $\mathrm{H}_{2} \mathrm{O}$ 
Appendix I (continued). Sericite Analyses. Southwest Tintic. SUT 4 ShT 5

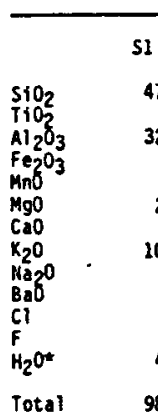

\begin{tabular}{rr} 
& \multicolumn{1}{c}{$s 2$} \\
47.6 & 46.8 \\
32.06 & .49 \\
32.4 & 33.9 \\
.59 & .7 \\
.01 & .01 \\
2.32 & 1.69 \\
.02 & .02 \\
10.8 & 10.3 \\
.34 & .43 \\
.17 & .1 \\
.02 & .03 \\
.49 & .36 \\
4.28 & 4.3
\end{tabular}

$53 \quad 55$

$55 \quad 56$

56

51
44.7
34.48
1.85
.00
1.56
.00
10.9
.71
.36
.01
.27
1.34

52
44.9
.33
33.7
1.71
.00
2.81
.01
10.7
.69
.40
.01
.59
4.18
9.8

53

$53 \quad 54$

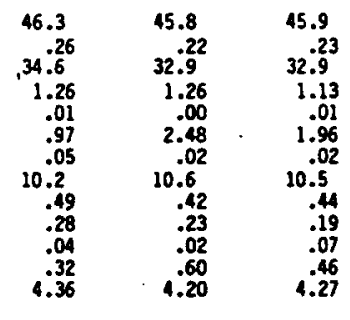

$99.1 \quad 99.0$

98.5

97.8

99.9

99.8

$\begin{array}{cc}44.8 & 44.9 \\ 34.50 & .48 \\ 1.79 & 33.8 \\ .01 & 1.78 \\ 1.82 & .00 \\ .01 & 1.95 \\ 10.9 & .00 \\ .62 & 10.5 \\ & .65 \\ & .00 \\ 4.48 & .02 \\ & 4.21\end{array}$

99.3

98.9

Numbers of Ions on the Basis of 22 Total Negative Charges 10(0) and $2(\mathrm{OH}, \mathrm{F}, \mathrm{C})$
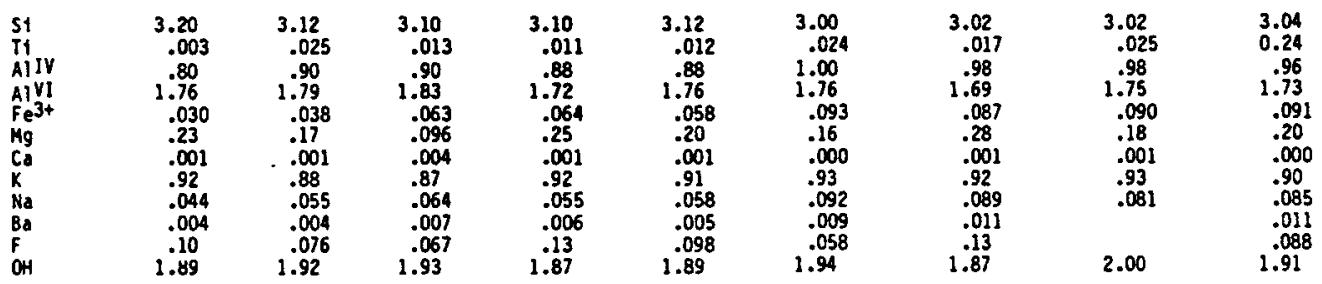

SWT 5

SWT 6

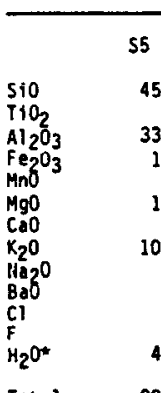

56

57

58

59

$518 \quad 52 B$

\section{$51-2 C$}

$52-2 C$

$\begin{array}{cc}45.2 & 44.9 \\ .57 & .67 \\ 33.9 & 34.3 \\ 1.73 & 1.72 \\ .01 & .00 \\ 1.56 & 1.50 \\ .01 & .01 \\ 10.8 & 10.8 \\ .67 & .61 \\ .36 & .25 \\ .01 & .01 \\ .42 & .35 \\ 4.27 & 4.31\end{array}$

45.4
34.46
1.54
.00
1.45
.01
10.7
.66
.33
.01
.39
4.30

44.9
34.53

2.11

.00
1.78
.00

1.78
.00
10.9
.68

0.9
.68
.37
.00

.00
.26
4.34

45.0
33.53
2.00
.00
1.412
.00
10.9
.68
.40
.02
.33
4.31

47.7
35.7

48.5

49.4

50.5

$\begin{array}{rr}35.7 & 34.1 \\ .88 & .86\end{array}$

33.9

34.7

6.30
.03
8.52

5.41
.00
9.53

.00
9.53
.33

2.18

2.18
.00
9.76
.38

2.58
.00

8.52
.35

.55
4.31

.71
4.22

.4 .67

.40
4.39

99.7

99.8

98.7

104.2

103.3

101.2

103.2

Number of lons on the Basis of 22 Total Negative Charges $10(0)$ and $2(\mathrm{OH}, \mathbf{F}, \mathrm{C})$

\begin{tabular}{|c|c|c|c|c|c|c|c|c|c|}
\hline $\begin{array}{l}51 \\
T i \\
\text { AlIV } \\
\text { AlVI } \\
\mathrm{Fe}^{3+} \\
\mathrm{Mg} \\
\mathrm{Cg} \\
\mathrm{K} \\
\mathrm{Ma} \\
\mathrm{Ba}\end{array}$ & $\begin{array}{c}3.05 \\
.029 \\
.95 \\
1.74 \\
.088 \\
.16 \\
.001 \\
.93 \\
.087 \\
.009\end{array}$ & $\begin{array}{c}3.03 \\
.034 \\
.97 \\
1.76 \\
.087 \\
.15 \\
.001 \\
.92 \\
.080 \\
.007\end{array}$ & $\begin{array}{c}3.04 \\
.023 \\
.96 \\
1.77 \\
.083 \\
.14 \\
.001 \\
.91 \\
.085 \\
.009\end{array}$ & $\begin{array}{l}3.02 \\
.027 \\
.98 \\
1.72 \\
.11 \\
.18 \\
.000 \\
.93 \\
.089 \\
.010\end{array}$ & $\begin{array}{c}3.06 \\
.022 \\
.94 \\
1.74 \\
.10 \\
.14 \\
.000 \\
.94 \\
.089 \\
.011\end{array}$ & $\begin{array}{c}3.00 \\
.002 \\
1.00 \\
1.65 \\
.042 \\
.59 \\
.002 \\
.68 \\
.043\end{array}$ & $\begin{array}{l}3.09 \\
.002 \\
.91 \\
1.65 \\
.041 \\
.51 \\
.000 \\
.77 \\
.041\end{array}$ & $\begin{array}{l}3.20 \\
.004 \\
.80 \\
1.79 \\
.040 \\
.21 \\
.000 \\
.81 \\
.047\end{array}$ & $\begin{array}{l}3.20 \\
.004 \\
.80 \\
1.79 \\
.041 \\
.24 \\
.000 \\
.77 \\
.042\end{array}$ \\
\hline OH & $\begin{array}{c}.090 \\
1.91\end{array}$ & $\begin{array}{l}.074 \\
1.92\end{array}$ & 1.083 & 1.055 & $\begin{array}{l}.070 \\
1.93\end{array}$ & $\begin{array}{r}.11 \\
-\quad 1.89\end{array}$ & $\begin{array}{r}.14 \\
1.86\end{array}$ & $\begin{array}{r}.14 \\
1.86\end{array}$ & $\begin{array}{l}.081 \\
1.92\end{array}$ \\
\hline
\end{tabular}

* Calculated $\mathrm{H}_{2} \mathrm{O}$ 
Appendix I (continued).

Sericite Analyses. Southwest Tintic.

SWT 7

\begin{tabular}{|c|c|c|c|c|c|}
\hline & $512-15$ & 57.9 & S16 & 518 & 56 \\
\hline $\begin{array}{l}\mathrm{SHO}_{2} \\
\mathrm{IiO}_{2} \\
\mathrm{Al}_{2} \mathrm{O}_{3} \\
\mathrm{Fe}_{2} \mathrm{O}_{3}\end{array}$ & $\begin{array}{r}50.9 \\
31.02 \\
2.04\end{array}$ & $\begin{array}{c}50.9 \\
31.02 \\
1.61\end{array}$ & $\begin{array}{c}49.9 \\
31.03 \\
2.90\end{array}$ & $\begin{array}{c}47.8 \\
30.03 \\
2.57\end{array}$ & $\begin{array}{r}48.6 \\
31.03 \\
2.93\end{array}$ \\
\hline $\begin{array}{l}\mathrm{MgO} \\
\mathrm{C}_{20} \\
\mathrm{~K}_{20} \\
\mathrm{MazO}^{2} \mathrm{O} \\
\mathrm{BaOO} \\
\mathrm{Cl}\end{array}$ & $\begin{array}{r}2.07 \\
.19 \\
9.77 \\
.00\end{array}$ & $\begin{array}{r}2.30 \\
.33 \\
9.50 \\
.00\end{array}$ & $\begin{array}{r}2.63 \\
.42 \\
.77\end{array}$ & $\begin{array}{r}2.76 \\
.28 \\
9.73 \\
.00\end{array}$ & $\begin{array}{r}3.07 \\
.32 \\
9.47 \\
.00\end{array}$ \\
\hline $\mathrm{H}_{2} \mathrm{O}^{*}$ & $4.42^{.30}$ & $4.40^{.36}$ & $4.40^{.29}$ & $4.40^{.26}$ & $4.42^{\circ}$ \\
\hline Total & 100.8 & 100.7 & 101.3 & 98.5 & 100.3 \\
\hline
\end{tabular}

Number of lons on the Basis of 22 Total Megative Charges $10(0)$ and $2(\mathrm{OH}, \mathrm{F}, \mathrm{C})$

$\begin{array}{lccccc}S 1 & 3.28 & 3.31 & 3.25 & 3.21 & 3.20 \\ \text { II } & .001 & .001 & .002 & .002 & .001 \\ \text { Aliv } & .72 & .69 & .75 & .79 & .80 \\ \text { AlVI } & 1.73 & 1.72 & 1.64 & 1.65 & 1.64 \\ F^{3+} & .10 & .079 & .142 & .13 & .15 \\ \mathrm{Mg} & .20 & .22 & .26 & .28 & .30 \\ \mathrm{Ca} & .014 & .023 & .029 & .020 & .023 \\ \mathrm{~K} & .81 & .79 & .81 & .84 & .80 \\ \mathrm{Na} & .000 & .000 & .000 & .000 & .000 \\ \mathrm{Ba} & & & & & \\ \mathrm{F} & .061 & .073 & .059 & .055 & .049 \\ \mathrm{OH} & 1.94 & 1.93 & 1.94 & 1.95 & 1.95\end{array}$

SKT 6

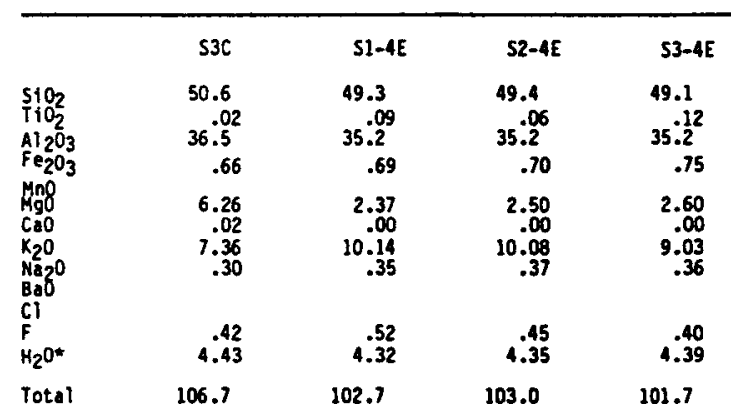

Number of ions on the basis of 22 total negative charges. $10(0)$ and $2(O H, F, C)$

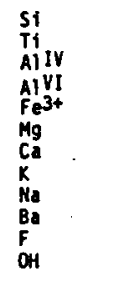

$\begin{array}{ll}3.07 & 3.15 \\ .001 & .004 \\ .93 & .85 \\ 1.68 & 1.81 \\ .044 & .033 \\ .57 & .23 \\ .001 & .000 \\ .57 & .83 \\ .035 & .044 \\ .080 & .11 \\ 1.92 & 1.90\end{array}$

$\begin{array}{ll}3.15 & 3.15 \\ .003 & .006 \\ .85 & .85 \\ 1.80 & 1.81 \\ .034 & .082 \\ .24 & .25 \\ .000 & .000 \\ .82 & .74 \\ .045 & .045 \\ .091 & .002 \\ 1.91 & 1.92\end{array}$

* Caiculated $\mathrm{H}_{2} \mathrm{O}$ 
Appendix II. Sericite analyses: Santa Rita.

\begin{tabular}{|c|c|c|c|c|c|c|c|c|c|c|c|c|c|c|c|c|c|c|c|c|c|c|c|c|c|c|c|}
\hline & 5811 & & & SR17 & & & & SR18 & & SA2O & & & & & SR21 & & & & SR28 & & 5830 & & SR5O & & & & \\
\hline & M9 & M10 & m21 & M6 & m9: & M9b & $M 9 c$ & 12 & & $M$ & M5 & M6 & MT & פו & HR & M3 & $m$ & M6 & M3 & $M 7$ & mo & $m$ & MS & M6 & xา & B & mo \\
\hline 102 & 44.2 & 44.1 & 44.7 & 45.9 & 46.9 & 46.6 & 47.0 & 45.4 & 45.9 & 45.2 & 45.6 & 45.2 & 46.8 & 46.0 & 45.4 & 46.0 & 45.9 & 45.2 & 41.3 & 47.3 & 49.0 & 48.8 & 47.4 & 47.2 & 47.4 & 46.8 & 17.2 \\
\hline 1102 & .38 & .37 & .56 & 1.90 & 1.19 & .59 & 1.47 & .35 & .87 & 3.56 & 2.63 & 2.42 & 1.23 & 1.83 & .31 & .30 & .19 & .70 & .21 & 1.36 & .14 & .35 & .19 & .11 & .47 & .38 & .41 \\
\hline 1203 & 31.6 & 31.4 & 32.3 & 33.4 & 33.8 & 34.1 & 34.4 & 33.9 & 33.8 & 34.8 & 33.3 & 34.0 & 33.9 & 33.6 & 33.5 & 33.8 & 33.2 & 33.6 & 30.4 & 29.1 & 31.7 & 29.4 & 33.9 & 33.6 & 34.4 & 33.8 & 33.6 \\
\hline 6203 & 4.21 & 4.05 & 4.11 & 2.31 & 2.08 & 1.71 & 2.22 & 1.42 & 1.53 & 3.71 & 3.72 & 4.48 & 2.67 & 3.19 & 3.21 & 3.25 & 2.28 & 3.30 & 3.18 & 5,41 & 2.95 & 4.01 & .85 & 1.12 & .92 & .90 & 1.00 \\
\hline no & .02 & .02 & .03 & .01 & .03 & .02 & .03 & .02 & .03 & .01 & .00 & .01 & .01 & .03 & :05 & .05 & .01 & .03 & .06 & .05 & .05 & $.0 r$ & .00 & .00 & .02 & .00 &.$\infty 0$ \\
\hline 60 & 2.28 & 2.44 & 2.48 & 1.03 & 1.12 & 1.00 & 1.11 & 1.02 & .94 & .83 & .92 & 1.06 & 1.05 & 1.08 & 1.17 & 1.15 & 1.01 & 1.02 & 1.54 & 1.11 & 1.33 & 1.91 & 1.19 & 1.43 & 1.06 & 1.21 & 1.24 \\
\hline CAO & .02 & .01 & .02 & .03 & .01 & .02 & .03 & .02 & .05 & .00 & .04 & .04 & .03 & .02 & .01 & .01 & .02 & .01 & .04 & .08 & .06 & .03 & .00 & .02 & .02 & .01 & .01 \\
\hline 20 & 10.5 & 10.3 & 10.1 & 10.9 & 11.0 & 11.0 & 10.1 & 11.15 & 10.9 & 10.4 & 10.5 & 10.6 & 10.3 & 10.8 & 10.3 & 10.0 & $! 11.0$ & 11.1 & 10.6 & 10.6 & $10.7^{-}$ & 10.6 & 10.5 & 10.7 & 10.3 & 10.6 & 30.6 \\
\hline 420 & .41 & .31 & .41 & .37 & .42 & .12 & .43 & .44 & .42 & .38 & .38 & .38 & .31 & .37 & .40 & .41 & .44 & .42 & .18 & .09 & .16 & .23 & .46 & .44 & .45 & .45 & .15 \\
\hline $8 A 0$ & .16 & .09 & .08 & .14 & .30 & .23 & .18 & .20 & .21 & .10 & .13 & .13 & .24 & .12 & .10 & .14 & .14 & .06 & .09 & .07 & .06 & .10 & .15 & .13 & .14 & .16 & .10 \\
\hline CL & .02 & .07 & .02 &.$\infty$ & .00 & .00 & .00 & .00 & .00 & .01 & .01 & .01 & .00 & .00 & .01 & .01 & .00 & .00 &.$\infty$ & .00 & .00 & .00 & .00 & .00 & .00 & .00 & .00 \\
\hline & .26 & .22 & .22 & .10 & .08 & .08 & .10 & .11 & .10 & .13 & .08 & .08 & .09 & .10 & .16 & .14 & .12 & .13 & .12 & .10 & .09 & .13 & .12 & .13 & .11 & .12 & .14 \\
\hline 120* & 4.31 & 4.33 & 4.35 & 4.43 & 4.45 & 4.46 & 4.45 & 4.44 & 4.45 & 4.40 & 4.42 & 4.41 & 4.45 & 4.42 & 4.41 & 4.43 & 4.43 & 4.40 & 9.43 & 9.40 & 4.41 & 4.42 & 4.47 & 4.46 & 4.48 & 9.46 & 4.46 \\
\hline OTAL & 98.4 & 98.3 & 99.4 & 100.4 & 101.3 & 100.1 & 102.2 & 98.3 & 99.1 & 103.5 & 101.6 & 102. & $10 t .1$ & 101.6 & 99.0 & 99.71 & 98.8 & 99.9 & 98.1 & 99.7 & 100.7 & 100.1 & 99.2 & | 99.1 & 99.7 & 98.9 & 99.1 \\
\hline \multicolumn{28}{|c|}{ Mumbers of tons on the basis of 22 total negattive charges, $10(0)$ and $2(O H, F, C l)$} \\
\hline & 3.03 & 3.06 & 3.02 & 3.05 & 3.09 & 3.10 & 3.07 & 3.09 & 3.09 & 2.93 & 3.01 & 2.96 & 3.06 & 3.04 & 3.07 & 3.08 & 3.11 & 3.04 & 3.22 & 3.19 & 3.24 & 3.26 & 3.16 & 3.15 & 3.14 & 3.14 & 3.15 \\
\hline 1 & .02 & .02 & .03 & .10 & .06 & .03 & .07 & .02 & .04 & .11 & .13 & .12 & .06 & .09 & .02 & .02 & .01 & .04 & .01 & .07 & .01 & .02 & .01 & .01 & .02 & .02 & .02 \\
\hline iv & .91 & .94 & .98 & .95 & .91 & $\bullet .90$ & .93 & .91 & 91 & 1.07 & .99 & 1.04 & .92 & .96 & .93 & .92 & .89 & .96 & .78 & .81 & .76 & .70 & .84 & .85 & .86 & .86 & .85 \\
\hline ALVI & 1.59 & 1.59 & 1.59 & 1.67 & 1.71 & 1.77 & 1.71 & 1.80 & 1.11 & 1.59 & 1.60 & 1.58 & 1.71 . & 1.65 & 1.73 & 1.74 & 1.76 & 1.70 & 1.66 & 1.51 & 1.70 & 1.51 & 1.82 & 1.79 & 1.83 & 1.81 & 1.80 \\
\hline $3+$ & .22 & .21 & .21 & .12 & .10 & .09 & .11 & .07 & .08 & .18 & .18 & .22 & .13 & .16 & .16 & .16 & .12 & .11 & .16 & .28 & .15 & .20 & .04 & .06 & .05 & .05 & .05 \\
\hline & .00 & .00 & .00 & .00 & .00 & .00 & .00 & .0 & .00 & .00 & .00 & .00 & .00 & .00 & .00 & .00 & .00 & .00 & .00 & .00 & .00 & .00 & .00 & .00 & .00 & .00 & .00 \\
\hline MG & .23 & .25 & .25 & .10 & .11 & .10 & .11 & .10 & .09 & .08 & .09 & .10 & .10 & .11 & .12 & .11 & .10 & .10 & .16 & .11 & .13 & .19 & .12 & .14 & .10 & .12 & .12 \\
\hline CA & .00 & .00 & .00 & .00 & .00 & .00 & .00 & .00 & .00 & .00 & .00 & .00 & .00 & .00 & .00 & .00 & .00 & .00 & .00 & .01 & .00 & .00 & .00 & .00 & .00 & .00 & .00 \\
\hline & .92 & .90 & .87 & .92 & .92 & .93 & .89 &. .96 & .94 & .86 & .88 & .88 & .81 & .91 &.$A B$ & .86 & .95 & .95 & .92 & .91 & .90 & .91 & .90 & .91 & .87 & .91 & .90 \\
\hline NA & .05 & .05 & .05 & .05 & .05 & .05 & .05 & .06 & .05 & .05 & .05 & .05 & .05 & .05 & .05 & .05 & .06 & .05 & .02 & .01 & .02 & .03 & .06 & 1.06 & .06 & .06 & .06 \\
\hline$B A$ & .00 & .00 & .00 & .00 & .01 & .01 & .00 & .01 & .01 & .00 & .00 & .00 & .01 & .00 & .00 & .00 & .00 &.$\infty$ & .00 & .00 & .00 & .00 & .00 & .00 & .00 & .00 & .00 \\
\hline CL & .00 & .01 &.$\infty$ & .00 & .00 & .00 & .00 & .00 & .00 & .00 & .00 & .00 & .0 & .00 & .00 & .00 & .00 & .00 & .00 & .00 & .00 & .00 & .00 & .00 & .00 & .00 & .00 \\
\hline r & .06 & .05 & .05 & .02 & .02 & .02 & .02 & .02 & .02 & .03 & .02 & .02 & .02 & .02 & .03 & .03 & .03 & .03 & .03 & .02 & .02 & .03 & .03 & .03 & .02 & .03 & .03 \\
\hline in & 1.94 & 1.95 & $1.95^{\circ}$ & 1.98 & 1.98 & 1.98 & 1.98 & 1.98 & 1.98 & 1.97 & 1.98 & 1.98 & 1.98 & 1.98 & 1.96 & 1.97 & 1.97 & 1.97 & 1.91 & 1.98 & 1.98 & 1.97 & 1.97 & 1.97 & 1.98 & 1.97 & 1.97 \\
\hline
\end{tabular}


Appendix III. Sericite Analyses: Roosevelt Well 14-2** 503

610

S2S2-2 S2-3 S2-5 S2-6

\begin{tabular}{|c|c|c|c|c|c|c|c|c|}
\hline & $2-1$ & s2-2 & $52-3$ & S2-5 & $52-6$ & S3B-3 & $53 B-4$ & S1A-2 \\
\hline $\begin{array}{l}\mathrm{SiO}_{2} \\
\mathrm{TiO}_{2} \\
\mathrm{Al}_{2} \mathrm{O}_{3} \\
\mathrm{Fe}_{2} \mathrm{O}_{3} \\
\mathrm{MnO}\end{array}$ & $\begin{array}{c}49.2 \\
.01 \\
35.0 \\
1.94\end{array}$ & $\begin{array}{c}48.7 \\
.01 \\
37.2 \\
.49\end{array}$ & $\begin{array}{c}48.7 \\
.01 \\
36.5 \\
1.45\end{array}$ & $\begin{array}{c}49.8 \\
.05 \\
32.9 \\
3.40\end{array}$ & $\begin{array}{c}50.2 \\
.11 \\
29.2 \\
5.18\end{array}$ & $\begin{array}{c}50.0 \\
.02 \\
29.7 \\
4.96\end{array}$ & $\begin{array}{c}52.1 \\
.00 \\
33.4 \\
1.90\end{array}$ & $\begin{array}{c}49.9 \\
.01 \\
34.6 \\
1.91\end{array}$ \\
\hline $\begin{array}{l}\mathrm{MgO} \\
\mathrm{CaO} \\
\mathrm{K}_{2} \mathrm{O} \\
\mathrm{Na} \mathrm{O}^{\circ} \\
\mathrm{BaO} \\
\mathrm{Cl}\end{array}$ & $\begin{array}{r}.80 \\
.03 \\
7.21 \\
.09\end{array}$ & $\begin{array}{l}.07 \\
.14 \\
.984 \\
.08\end{array}$ & $\begin{array}{r}.60 \\
.07 \\
9.17 \\
.12\end{array}$ & $\begin{array}{r}1.69 \\
.04 \\
5.02 \\
.10\end{array}$ & $\begin{array}{r}3.06 \\
.03 \\
9.50 \\
.15\end{array}$ & $\begin{array}{r}2.82 \\
.11 \\
9.53 \\
.13\end{array}$ & $\begin{array}{r}.86 \\
.08 \\
8.78 \\
.13\end{array}$ & $\begin{array}{r}.77 \\
.09 \\
9.29 \\
.17\end{array}$ \\
\hline $\mathrm{F}$ & $\begin{array}{r}.24 \\
4.52\end{array}$ & $\begin{array}{r}.15 \\
4.51\end{array}$ & $\begin{array}{r}.14 \\
4.52\end{array}$ & .4 .41 & .60 & $\begin{array}{r}.47 \\
4.29\end{array}$ & $\begin{array}{r}.28 \\
4.48\end{array}$ & 4.18 \\
\hline Total & 99.0 & 101.0 & 101.2 & 97.7 & 102.0 & 101.8 & 101.9 & 101.3 \\
\hline \multicolumn{9}{|c|}{$\begin{array}{l}\text { Numbers of ions calculated on the basis of } 22 \text { total negative charges, } \\
10(0) \text { and } 2(\mathrm{OH}, \mathrm{F}, \mathrm{Cl})\end{array}$} \\
\hline $\begin{array}{l}\mathrm{Si} \\
\mathrm{Tj} \\
\mathrm{Al} I \mathrm{IV} \\
\mathrm{Al} \mathrm{VI} \\
\mathrm{Fe} 3+ \\
\mathrm{Mg} \\
\mathrm{Ca} \\
\mathrm{K} \\
\mathrm{Na} \\
\mathrm{Ba}\end{array}$ & $\begin{array}{c}3.21 \\
.000 \\
.79 \\
1.91 \\
.095 \\
.078 \\
.002 \\
.601 \\
.012\end{array}$ & $\begin{array}{c}3.15 \\
.000 \\
.85 \\
1.98 \\
.024 \\
.007 \\
.009 \\
.811 \\
.010\end{array}$ & $\begin{array}{c}3.14 \\
.000 \\
.86 \\
1.91 \\
.07 \\
.058 \\
.005 \\
.755 \\
.015\end{array}$ & $\begin{array}{c}3.27 \\
.002 \\
.73 \\
1.82 \\
.168 \\
.166 \\
.003 \\
.421 \\
.012\end{array}$ & $\begin{array}{c}3.27 \\
.006 \\
.73 \\
1.51 \\
.254 \\
.297 \\
.002 \\
.790 \\
.019\end{array}$ & $\begin{array}{c}3.26 \\
.001 \\
.74 \\
2.08 \\
2.44 \\
.274 \\
.008 \\
.794 \\
.016\end{array}$ & $\begin{array}{c}3.32 \\
.000 \\
.68 \\
1.83 \\
.091 \\
.082 \\
.006 \\
.714 \\
.016\end{array}$ & $\begin{array}{c}3.22 \\
.000 \\
.78 \\
1.85 \\
.093 \\
.074 \\
.007 \\
.765 \\
.022\end{array}$ \\
\hline $\mathrm{OH}$ & $\begin{array}{l}.049 \\
1.95\end{array}$ & $\begin{array}{l}.032 \\
1.97\end{array}$ & $\begin{array}{l}.029 \\
1.97\end{array}$ & $\begin{array}{l}.084 \\
1.92\end{array}$ & $\begin{array}{l}1.25 \\
1.88\end{array}$ & $\begin{array}{l}.097 \\
1.90\end{array}$ & $\begin{array}{l}.057 \\
1.94\end{array}$ & $\begin{array}{l}.036 \\
1.96\end{array}$ \\
\hline $\begin{array}{l}{ }^{*} \mathrm{C} \\
\mathrm{A} \\
\mathrm{r}\end{array}$ & $\begin{array}{l}\text { ses } \\
\text { ted }\end{array}$ & sam & 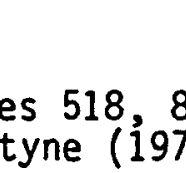 & , & & & e & \\
\hline
\end{tabular}


Appendix IV. Chlorite Analyses. Southwest Tintic.

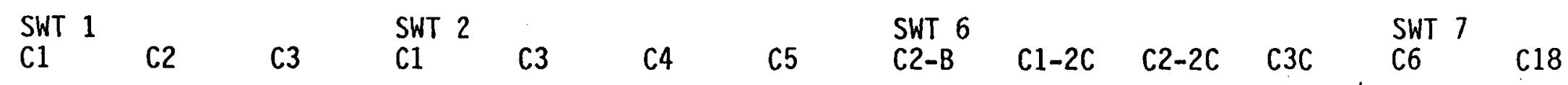

\begin{tabular}{|c|c|c|c|c|c|c|c|c|c|c|c|c|c|}
\hline $\begin{array}{l}\mathrm{SiO}_{2} \\
\mathrm{TiO}_{2} \\
\mathrm{Al}_{2} \mathrm{O}_{3} \\
\mathrm{FeO}\end{array}$ & $\begin{array}{c}27.4 \\
.06 \\
20.7 \\
17.4\end{array}$ & $\begin{array}{c}27.1 \\
.08 \\
20.4 \\
17.9\end{array}$ & $\begin{array}{c}28.0 \\
.09 \\
20.8 \\
17.9\end{array}$ & $\begin{array}{c}28.1 \\
.02 \\
20.5 \\
4.41\end{array}$ & $\begin{array}{c}28.6 \\
.02 \\
20.7 \\
4.34\end{array}$ & $\begin{array}{c}28.3 \\
.02 \\
20.5 \\
4.25\end{array}$ & $\begin{array}{c}29.8 \\
.13 \\
20.2 \\
4.10\end{array}$ & $\begin{array}{r}32.9 \\
.00 \\
23.0 \\
1.82\end{array}$ & $\begin{array}{c}31.9 \\
.01 \\
22.7 \\
2.17\end{array}$ & $\begin{array}{c}32.4 \\
.01 \\
23.7 \\
2.07\end{array}$ & $\begin{array}{c}32.8 \\
.00 \\
24.1 \\
1.83\end{array}$ & $\begin{array}{c}29.5 \\
.01 \\
22.1 \\
12.5\end{array}$ & $\begin{array}{c}29.1 \\
.02 \\
21.3 \\
12.3\end{array}$ \\
\hline $\begin{array}{l}\text { MnO } \\
\mathrm{MaO}\end{array}$ & $21 \cdot 10$ & 21.12 &. .11 & 29.7 & 29.02 & $\begin{array}{r}.02 \\
29.4\end{array}$ & 26.06 & 31.9 & 31.5 & 32,0 & 3 & 240 & $2 ?$ \\
\hline Cao & .05 & .03 & .04 & .06 & .06 & .08 & .19 & .02 & .02 & .02 & .03 & $\begin{array}{r}.34 \\
\end{array}$ & .38 \\
\hline $\mathrm{K}_{2} \mathrm{O}$ & .04 & .01 & .03 & .20 & .15 & . 16 & .1 & .04 & .03 & .02 & .04 & .0 & .03 \\
\hline $\mathrm{Na}_{2} \mathrm{O}$ & .04 & .02 & .03 & .05 & .05 & .07 & .03 & .00 & .00 & .00 & .01 & .07 & .07 \\
\hline $\mathrm{Ba} 0$ & .00 & .00 & .00 & & & & & & & & & & \\
\hline $\mathrm{Cl}$ & .02 & .04 & .01 & .01 & .01 & .00 & .00 & & & & & & \\
\hline $\begin{array}{l}\mathrm{F} \\
\mathrm{H}_{2} \mathrm{O}^{*}\end{array}$ & 11.9 & 11.8 & $11 . .98$ & 12.44 & $\begin{array}{r}.49 \\
12.4\end{array}$ & 12.46 & 12.58 & 12.89 & 12.83 & 12.84 & 12.92 & 12.31 & 12.0 \\
\hline Total & 99.5 & 99.5 & 100.5 & 95.9 & 96.2 & 95.7 & 93.7 & 103.1 & 101.7 & 103.6 & 104.1 & 100.9 & 17.6 \\
\hline
\end{tabular}

Numbers of ions calculated on the basis of 28 total negative charges $10(0)$ and $8(\mathrm{OH}, \mathrm{F}, \mathrm{Cl})$

\begin{tabular}{|c|c|c|c|c|c|c|c|c|c|c|c|c|c|}
\hline $\begin{array}{l}\text { Si } \\
\text { Ti } \\
\text { AlIV } \\
\text { AlVI } \\
\text { Fe } \\
\text { Mg }\end{array}$ & $\begin{array}{l}2.75 \\
.004 \\
1.25 \\
1.20 \\
1.46 \\
3.24\end{array}$ & $\begin{array}{c}2.73 \\
.006 \\
1.27 \\
1.15 \\
1.51 \\
3.27\end{array}$ & $\begin{array}{c}2.78 \\
.007 \\
1.22 \\
1.22 \\
1.49 \\
3.17\end{array}$ & $\begin{array}{r}2.78 \\
.00 \\
1.22 \\
1.17 \\
.42 \\
4.38\end{array}$ & $\begin{array}{r}2.81 \\
.00 \\
1.19 \\
1.21 \\
.41 \\
4.31\end{array}$ & $\begin{array}{r}2.80 \\
.00 \\
1.20 \\
1.20 \\
.40 \\
4.33\end{array}$ & $\begin{array}{r}3.00 \\
.01 \\
1.00 \\
1.41 \\
.40 \\
3.90\end{array}$ & $\begin{array}{c}2.95 \\
.000 \\
1.05 \\
1.39 \\
.16 \\
4.26\end{array}$ & $\begin{array}{c}2.92 \\
.001 \\
1.08 \\
1.37 \\
.19 \\
4.29\end{array}$ & $\begin{array}{c}2.90 \\
.000 \\
1.10 \\
1.40 \\
.18 \\
4.27\end{array}$ & $\begin{array}{c}2.91 \\
.000 \\
1.09 \\
1.43 \\
.16 \\
4.22\end{array}$ & $\begin{array}{l}2.81 \\
.001 \\
1.19 \\
1.29 \\
1.14 \\
3.41\end{array}$ & $\begin{array}{c}2.83 \\
.001 \\
1.17 \\
1.28 \\
1.32 \\
3.21\end{array}$ \\
\hline $\mathrm{Ca}$ & .005 & .003 & .004 & .01 & .01 & .01 & .02 & .002 & .002 & .002 & .003 & .035 & .040 \\
\hline K & .005 & .001 & .004 & .02 & .02 & .02 & .02 & .004 & .004 & .003 & .004 & .000 & .004 \\
\hline $\begin{array}{l}\mathrm{Na} \\
\mathrm{Ba}\end{array}$ & .008 & .004 & .006 & .00 & .01 & .01 & .01 & .000 & .001 & .000 & .002 & .020 & .014 \\
\hline $\begin{array}{l}\mathrm{F} \\
\mathrm{OH}\end{array}$ & $\begin{array}{l}.038 \\
7.96\end{array}$ & $\begin{array}{l}.057 \\
7.94\end{array}$ & $\begin{array}{l}.056 \\
7.94\end{array}$ & $\begin{array}{r}.14 \\
7.86\end{array}$ & $\begin{array}{r}.15 \\
7.85\end{array}$ & $\begin{array}{r}.14 \\
7.86\end{array}$ & $\begin{array}{r}.19 \\
7.81\end{array}$ & $\begin{array}{r}.25 \\
7.75\end{array}$ & $\begin{array}{r}.24 \\
7.76\end{array}$ & $\begin{array}{r}.24 \\
7.76\end{array}$ & $\begin{array}{r}.26 \\
7.74\end{array}$ & $\begin{array}{l}.093 \\
7.91\end{array}$ & $\begin{array}{l}.076 \\
7.92\end{array}$ \\
\hline
\end{tabular}

*Calculated $\mathrm{H}_{2} \mathrm{O}$ 
Appendix V. Thermodynamic Properties of Minerals.

\begin{tabular}{|c|c|c|c|}
\hline Mineral & $\Delta H_{f}^{\circ}, 298$ & $\underline{s^{0}}$ & $\underline{C p}$ \\
\hline $\begin{array}{l}\text { Muscovite* } \\
\mathrm{KAl}_{2} \mathrm{Si}_{3} \mathrm{AlO}_{1 \mathrm{O}}(\mathrm{PH})_{2}\end{array}$ & $-5,976,740$ & 305.4 & $9.1767 \times 1 \mathrm{U}-2-8.1110 \times 10-2 \mathrm{~T}-1.0348 \times 10^{4} \mathrm{~T}-0.5+2.8341 \times 106 \mathrm{~T}-2$ \\
\hline $\begin{array}{l}\text { Ferrimuscovite } \\
\mathrm{KFe}_{2} \mathrm{Si}_{3} \mathrm{AlO}_{10}(\mathrm{OH})_{2}\end{array}$ & $-5,125,680$ & 342.88 & $-78.300-2.4252 \mathrm{~T}-9.3500 \times 1 \mathrm{U}^{3} \mathrm{~T}-0.5+4.7310 \times 106 \mathrm{~T}-2+86.525 \mathrm{~T}^{0}-5+6.0519 \times 1 \mathrm{U}^{-4} \mathrm{~T}^{2}+2.7821 \times 10^{4} \mathrm{~T}^{-1}$ \\
\hline $\begin{array}{l}\text { Celadonite } \\
\mathrm{KMgAISi}_{4} \mathrm{O}_{10}(\mathrm{OH})_{2}\end{array}$ & $-5,848,790$ & 323.34 & $9.6587 \times 10^{2}-9.4625 \times 10^{-2} \mathrm{~T}-1.1658 \times 10^{4} \mathrm{~T}-0.5+5.9236 \times 10^{6} \mathrm{~T}-2$ \\
\hline $\begin{array}{l}\text { Illite } \\
\text { K.75!49.25Al } 1.75 \mathrm{Si} 3.5 \mathrm{Al} .5 \mathrm{U}_{10}\left(\mathrm{UH}_{2}\right)\end{array}$ & $-5,664.749$ & 1104.2 & $8.8059 \times 10^{2}-7.1916 \times 10^{-2}-9.7313 \times 10^{3} T^{-0}-5-2.5659 \times 10^{6} \mathrm{~T}-2+2.8014 \times 10^{-6} \mathrm{~T}^{2}$ \\
\hline $\begin{array}{l}\text { Clinochlore } \\
\mathrm{Mg}_{5} \mathrm{AlSi}_{3} \mathrm{AlO} \mathrm{O}_{1 \mathrm{O}}(\mathrm{OH})_{8}\end{array}$ & $-8,857,377$ & 441.0 & $1.0520 \times 10^{3}+3.965 \times 10^{-2} \mathrm{~T}-8.0618 \times 10^{3} \mathrm{~T}-0.5-3.2759 \times 10^{6} \mathrm{~T}-2$ \\
\hline $\begin{array}{l}\text { Uaphnite } \\
\text { Fe5AISiAlO } 10(\mathrm{OH})_{8}\end{array}$ & $-6,971,370$ & 531.97 & $9.1395+10^{2}+2.2516 \times 10^{-2 T}-3.7003 \times 10^{3} \mathrm{~T}^{-0.5}-1.0116 \times 10^{7} \mathrm{~T}-2+5.6028 \times 10^{-5} \mathrm{~T}^{2}$ \\
\hline $\begin{array}{l}\text { Pyrophyllite* } \\
\mathrm{Al}_{2} \mathrm{Si}_{4} \mathrm{U}_{1 \mathrm{U}}(\mathrm{UH})_{2}\end{array}$ & $-5,643,300$ & 293.4 & $7.4675 \times 10^{2}-5.3543 \times 10^{-2} \mathrm{~T}+1.9855 \times 10^{-5} \mathrm{~T}^{2}-7.5777 \times 10^{3} \mathrm{~T}-0.5$ \\
\hline $\begin{array}{l}\text { Low Albite* } \\
\text { NaAlSi } 3 \text { Oy }\end{array}$ & $-3,935,120$ & 207.4 & $5.8394 \times 10^{2}-0.092852 \mathrm{~T}+2.2722 \times 1 \mathrm{U}^{-5} \mathrm{~T}^{2}-6.4242 \times 10^{3} \mathrm{~T}-U .5-1.6780 \times 10^{6} \mathrm{~T}-2$ \\
\hline $\begin{array}{l}\text { Anorthite* } \\
\mathrm{CaAl}_{2} \mathrm{Si}_{2} \mathrm{O}_{8}\end{array}$ & $-4,243,040$ & 199.3 & $5.1683 \times 10^{2}-9.2492 \times 10^{-2} \mathrm{~T}+4.1883 \times 10^{-5} \mathrm{~T}^{2}-4.5885 \times 10^{-3} \mathrm{~T}^{-0}-5-1.4035 \times 10^{6} \mathrm{~T}^{-2}$ \\
\hline $\begin{array}{l}\text { Microcline } \\
\text { KAlsi } 30_{8}\end{array}$ & $-3,967,690$ & 214.2 & $7.5955 \times 1 U^{2}-0.21711 \mathrm{~T}+6.4333 \times 10^{-5} \mathrm{~T}^{2}-9.5268 \times 10^{3} \mathrm{~T}^{-0.5}+4.7642 \times 10^{6} \mathrm{~T}^{-2}$ \\
\hline
\end{tabular}

*From Robie et al. (1978). Others estimated from data in Robie et al.

(1978).

Units are joules/mole: 